\title{
Dissecting dynamics and differences of selective pressures in the evolution of human pigmentation
}

(1)

\author{
Xin Huang ${ }^{1, *}$, Yungang $\mathrm{He}^{3, *}$, Sijia Wang ${ }^{1,2}$, Li Jin ${ }^{1,2, *}$
}

${ }^{1}$ Chinese Academy of Sciences Key Laboratory of Computational Biology, Chinese Academy of Sciences-Max Planck Society Partner Institute for Computational Biology, Shanghai Institute of Nutrition and Health, Shanghai Institutes for Biological Sciences, University of Chinese Academy of Sciences, Chinese Academy of Sciences, Shanghai, 200031, China

${ }^{2}$ State Key Laboratory of Genetic Engineering and Ministry of Education Key Laboratory of Contemporary Anthropology, Collaborative Innovation Center for Genetics and Development, School of Life Sciences, Fudan University, Shanghai, 200433, China

${ }^{3}$ Institute of Biomedical Sciences, Shanghai Medical College, Fudan University, Shanghai, 200032, China

*Corresponding authors: xin.huang07@gmail.com (X.H.), heyungang@fudan.edu.cn (Y.H.), lijin@fudan.edu.cn (L.J.)

Keywords: population genetics, natural selection, human evolution, human pigmentation, complex traits 


\section{Abstract}

22 Human pigmentation is a highly diverse and complex trait among populations, and has drawn particular attention from both academic and non-academic investigators for thousands of years. Previous studies detected selection signals in several human pigmentation genes, but few studies have integrated contribution from multiple genes to the evolution of human pigmentation. Moreover, none has quantified selective pressures on human pigmentation over epochs and between populations. Here, we dissect dynamics and differences of selective pressures during different periods and between distinct populations with new approaches. We propose a new model with multiple populations to estimate historical selective pressures by summarizing selective pressures on multiple genes. We use genotype data of 19 genes associated with human pigmentation from 17 datasets, and obtain data for 2346 individuals of six representative population groups from worldwide. Our results quantify selective pressures on light pigmentation not only in modern Europeans (0.0249/generation) but also in proto-Eurasians (0.00665/generation). Our results also support several derived alleles associated with human dark pigmentation may under directional selection by quantifying differences of selective pressures between populations. Our study provides a first attempt to quantitatively investigate the dynamics of selective pressures during different time periods in the evolution of human pigmentation, and may facilitate studies of the evolution of other complex traits. 


\section{Author Summary}

42 The color variation of human skin, hair, and eye is affected by multiple genes with different

43 roles. This diversity may be shaped by natural selection and adapted for ultraviolet radiation

44 in different environments around the world. As human populations migrated out from Africa,

45 the ultraviolet radiation in the environment they encountered also changed. It is possible that

46 the selective pressures on human pigmentation varied throughout human evolutionary history.

47 In this study, we develop a new approach and estimate historical selective pressures on light

48 pigmentation not only in modern Europeans but also in proto-Eurasians. To our best

49 knowledge, this is the first study that quantifies selective pressures during different time

50 periods in the evolution of human pigmentation. Besides, we provide statistical evidence to

51 support several genes associated with human dark pigmentation may be favored by natural

52 selection. Thus, natural selection may not only affect light pigmentation in Eurasians, but also

53 influence dark pigmentation in Africans. 


\section{Introduction}

Human pigmentation - the color of human skin, hair, and eye - is one of the most diverse traits among populations. Its obvious diversity has attracted attention from both academic and non-academic investigators for thousands of years, as noted by Charles Darwin one century ago [1] and as noticed by ancient Egyptians more than 4000 years ago [2]. Why human pigmentation diverges, however, remains a central puzzle in human biology [3]. Some researchers have proposed that the diversity of human pigmentation is adapted for ultraviolet radiation (UVR) and driven by natural selection [4-6]. Dark skin may prevent sunburn amongst individuals in low latitude areas with high UVR, while light skin may protect infants against rickets in high latitude areas with low UVR [5-9]. A better understanding of how natural selection shapes the diversity of human pigmentation could provide relevant and beneficial information for public health [4-6].

During the last decade, many studies have applied statistical tests to detect signals of natural selection in several human pigmentation genes [10-18]. These genes encode different proteins, including: signal regulators-ASIP, KITLG, MC1R-stimulating the melanogenic pathway; possible enhancers-BNC2, HERC2-regulating pigmentation gene expression; important enzymes-TYR, TYRP1, DCT-converting tyrosine into melanin; putative exchangers-OCA2, SLC24A4, SLC24A5, SLC45A2, TPCN2 - controlling the environment within melanosomes; and an exocyst complex unit and molecular motor-EXOC2, MYO5A - conveying vesicles and organelles within the cytoplasm [19-33]. These proteins work at different stages of the melanogenic pathway, illustrating that human pigmentation is a complex trait affected by multiple genes with different roles.

Previous studies applied two groups of methods to detect natural selection. One group of methods detects unusually long extended haplotype homozygosity [10-16, 34, 35]. The other group of methods identifies extremely local population differentiation [10, 12-15, 17]. By applying both groups of methods, previous studies have aimed to interpret the evolution of individual pigmentation genes; however, few studies have integrated contributions from multiple genes to the evolution of human pigmentation. Moreover, none of these studies have quantitatively investigated the historical selective pressures of pigmentation genes during different epochs, and compared the differences of selective pressures between different 
populations. Therefore, it is necessary to perform an extensive quantification of selective pressures on human pigmentation using a creative approach.

\section{Results and Discussion}

\section{The model}

On the basis of a previous study [36], we measure selective pressures by (genic) selection coefficients. For any single nucleotide polymorphism (SNP) $L$, we can estimate the expectation of the selection (coefficient) difference per generation between populations $i$ and $j$ by

$$
d_{i j}(L)=\left[\ln \frac{p_{i}(L)}{q_{i}(L)}-\ln \frac{p_{j}(L)}{q_{j}(L)}\right] / t_{i j}
$$

where $p$ and $q$ are the frequencies of derived and ancestral alleles in a population, respectively; and $t_{i j}$ is the divergence time of the populations $i$ and $j$ from their most recent common ancestor. Details of the calculations are described elsewhere [36].

We can extend Eq. 1 to summarize selection differences of multiple SNPs, because a complex trait is usually affected by multiple loci. Here, we take two bi-allelic SNPs as an example. We can estimate the selection difference of a trait affected by two SNPs between populations $i$ and $j$ using

$$
d_{i j}\left(L_{1} L_{2}\right)=\left[\ln \frac{p_{i}\left(L_{1} L_{2}\right)}{q_{i}\left(L_{1} L_{2}\right)}-\ln \frac{p_{j}\left(L_{1} L_{2}\right)}{q_{j}\left(L_{1} L_{2}\right)}\right] / t_{i j}
$$

where $p\left(L_{1} L_{2}\right)$ is the frequency of the combination carrying two alleles associated with one possible outcome of a trait, such as light pigmentation; $q\left(L_{1} L_{2}\right)$ is the frequency of the combination carrying two alleles associated with another outcome of the same trait, such as dark pigmentation. With linkage equilibrium between $L_{1}$ and $L_{2}$, we have $p\left(L_{1} L_{2}\right)=$ $p\left(L_{1}\right) p\left(L_{2}\right)$ and $q\left(L_{1} L_{2}\right)=q\left(L_{1}\right) q\left(L_{2}\right)$. Thus,

$$
d_{i j}\left(L_{1} L_{2}\right)=d_{i j}\left(L_{1}\right)+d_{i j}\left(L_{2}\right)
$$

We further assume the distribution of selection difference in each SNP is identical and independent. Therefore, the variance of $d_{i j}\left(L_{1} L_{2}\right)$ is

$$
\operatorname{var}\left[d_{i j}\left(L_{1} L_{2}\right)\right]=\operatorname{var}\left[d_{i j}\left(L_{1}\right)\right]+\operatorname{var}\left[d_{i j}\left(L_{2}\right)\right] .
$$

The confidence interval $(\mathrm{CI})$ of $d_{i j}\left(L_{1} L_{2}\right)$ becomes $d_{i j}\left(L_{1} L_{2}\right) \pm 1.96 \sqrt{\operatorname{var}\left[d_{i j}\left(L_{1} L_{2}\right)\right]}$. 
More generally, for a trait with $n$ SNPs in linkage equilibrium as well as independent and identically distributed selection differences, the expectation and variance of the total selection difference in this trait is

$$
\begin{aligned}
d_{i j}\left(L_{1} L_{2} \cdots L_{n}\right) & =\sum_{i=1}^{n} d_{i j}\left(L_{k}\right) \\
\operatorname{var}\left[d_{i j}\left(L_{1} L_{2} \cdots L_{n}\right)\right] & =\sum_{i=1}^{n} \operatorname{var}\left[d_{i j}\left(L_{k}\right)\right]
\end{aligned}
$$

Based on Eq. 2, we develop a new approach for dissecting historical selective pressures over epochs of the human evolutionary history. We simplify the evolutionary history of six representative human populations as a binary tree (Fig. 1).

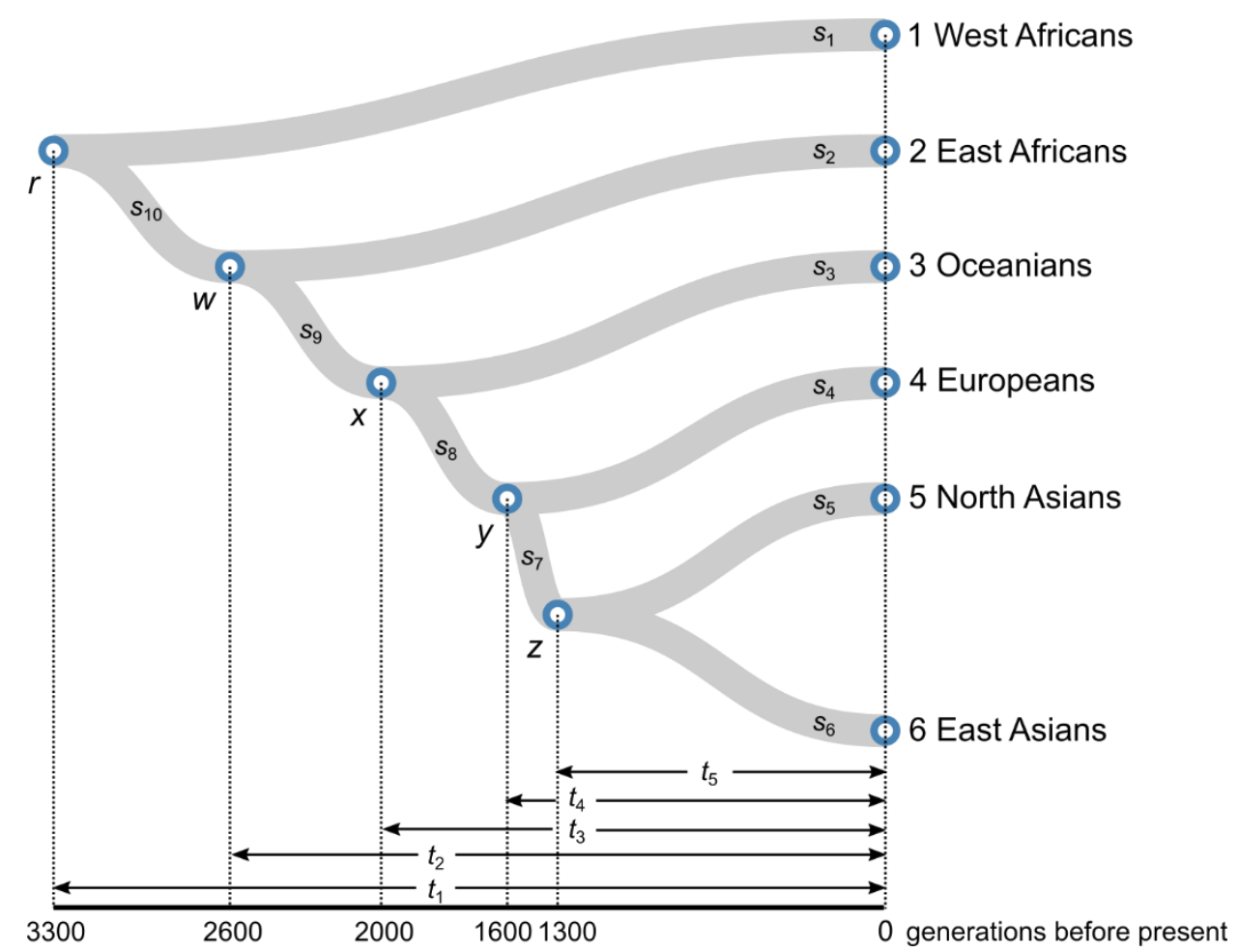

Fig. 1. Time-varied selective pressures on an evolutionary tree. We model the evolutionary history of six representative human populations as a binary tree. Here, $s_{i}(i=0,1, \ldots, 10)$ denotes the selection coefficient of the $i$-th epoch and can be obtained by estimating selection differences between paired populations. The numbers on the branches indicate different epochs. Divergence times between populations were based on previous studies [37-40]. We assumed one generation time is $\sim 30$ years. We obtain an optimal solution deviated least from neutral evolution using a probabilistic approach. The optimal solution (/generation) is $s_{1}^{*}=$ $-0.0188, s_{2}^{*}=-0.0204, s_{3}^{*}=-0.00614, s_{4}^{*}=0.0249, s_{5}^{*}=0.00622, s_{6}^{*}=-0.00480, s_{7}^{*}=$ $0.000218, s_{8}^{*}=0.00665, s_{9}^{*}=0.00813, s_{10}^{*}=0.00398$. In the solution, numbers larger than 
zero suggest natural selection favored light pigmentation, while those less than zero indicate natural selection preferred dark pigmentation.

When $k$ is the most recent common ancestor of $i$ and $j$, we can divide $d_{i j}$ in Eq. 1 into separate terms:

$$
d_{i j} t_{i j}=\left(\ln \frac{p_{i}}{q_{i}}-\ln \frac{p_{k}}{q_{k}}\right)-\left(\ln \frac{p_{j}}{q_{j}}-\ln \frac{p_{k}}{q_{k}}\right) .
$$

We can further divide the selection difference between paired populations into multiple terms, if there are multiple branches between them. For example, using the notations and demographic model in Fig. 1, we can estimate the total selection difference between East and West Africans as

$$
d_{21} t_{1}=-\left(\ln \frac{p_{1}}{q_{1}}-\ln \frac{p_{r}}{q_{r}}\right)+\left(\ln \frac{p_{2}}{q_{2}}-\ln \frac{p_{w}}{q_{w}}\right)+\left(\ln \frac{p_{w}}{q_{w}}-\ln \frac{p_{r}}{q_{r}}\right) .
$$

Let $s_{1}=\left(\ln \frac{p_{1}}{q_{1}}-\ln \frac{p_{r}}{q_{r}}\right) / t_{1}, s_{2}=\left(\ln \frac{p_{2}}{q_{2}}-\ln \frac{p_{w}}{q_{w}}\right) / t_{2}, s_{10}=\left(\ln \frac{p_{w}}{q_{w}}-\ln \frac{p_{r}}{q_{r}}\right) /\left(t_{1}-t_{2}\right)$, then we have

$$
d_{21} t_{1}=-s_{1} t_{1}+s_{2} t_{2}+s_{10}\left(t_{1}-t_{2}\right) .
$$

Therefore, we can represent the selection difference between paired populations as a combination of selection coefficients during different time periods. Using matrix algebra, we can represent the selection differences of all the paired populations in Fig. 1 as

$$
\mathrm{d}=\mathrm{Ts} \text {, }
$$

where

$$
\mathbf{T}=\left[\begin{array}{cccccccccc}
-t_{1} & t_{2} & 0 & 0 & 0 & 0 & 0 & 0 & 0 & t_{1}-t_{2} \\
-t_{1} & 0 & t_{3} & 0 & 0 & 0 & 0 & 0 & t_{2}-t_{3} & t_{1}-t_{2} \\
-t_{1} & 0 & 0 & t_{4} & 0 & 0 & 0 & t_{3}-t_{4} & t_{2}-t_{3} & t_{1}-t_{2} \\
-t_{1} & 0 & 0 & 0 & t_{5} & 0 & t_{4}-t_{5} & t_{3}-t_{4} & t_{2}-t_{3} & t_{1}-t_{2} \\
-t_{1} & 0 & 0 & 0 & 0 & t_{5} & t_{4}-t_{5} & t_{3}-t_{4} & t_{2}-t_{3} & t_{1}-t_{2} \\
0 & -t_{2} & t_{3} & 0 & 0 & 0 & 0 & 0 & t_{2}-t_{3} & 0 \\
0 & -t_{2} & 0 & t_{4} & 0 & 0 & 0 & t_{3}-t_{4} & t_{2}-t_{3} & 0 \\
0 & -t_{2} & 0 & 0 & t_{5} & 0 & t_{4}-t_{5} & t_{3}-t_{4} & t_{2}-t_{3} & 0 \\
0 & -t_{2} & 0 & 0 & 0 & t_{5} & t_{4}-t_{5} & t_{3}-t_{4} & t_{2}-t_{3} & 0 \\
0 & 0 & -t_{3} & t_{4} & 0 & 0 & 0 & t_{3}-t_{4} & 0 & 0 \\
0 & 0 & -t_{3} & 0 & t_{5} & 0 & t_{4}-t_{5} & t_{3}-t_{4} & 0 & 0 \\
0 & 0 & -t_{3} & 0 & 0 & t_{5} & t_{4}-t_{5} & t_{3}-t_{4} & 0 & 0 \\
0 & 0 & 0 & -t_{4} & t_{5} & 0 & t_{4}-t_{5} & 0 & 0 & 0 \\
0 & 0 & 0 & -t_{4} & 0 & t_{5} & t_{4}-t_{5} & 0 & 0 & 0 \\
0 & 0 & 0 & 0 & -t_{5} & t_{5} & 0 & 0 & 0 & 0
\end{array}\right] .
$$

To obtain the optimal solution, we propose a probabilistic approach. Under neutral evolution (NE), we consider each estimated $s$ as an independent random variable following a 
normal distribution with a mean of zero and a variance of $\sigma^{2}$. For each solution with ten variables, the summation below follows a chi-square distribution with ten degrees of freedom:

$$
\sum_{i=1}^{10} \frac{s_{i}^{2}}{\sigma_{i}^{2}} \sim \chi^{2}(10)
$$

Therefore, we have $\operatorname{Pr}\left(|\mathbf{s}|^{2}>\left|\mathbf{s}_{a}\right|^{2} \mid \mathrm{NE}\right) \geq \operatorname{Pr}\left(|\mathbf{s}|^{2}>\left|\mathbf{s}_{b}\right|^{2} \mid \mathrm{NE}\right)$, if $\left|\mathbf{s}_{a}\right|^{2} \leq\left|\mathbf{s}_{b}\right|^{2}$ for solutions $a$ and $b$. Here, $|\mathbf{s}|^{2}$ is the norm of a vector $\mathbf{s}$. In other words, we can choose the most conservative solution with the least deviation from neutral evolution using a probabilistic approach. Thus, the optimal solution $\mathbf{s}^{*}$ is

$$
\mathbf{s}^{*}=\mathrm{T}^{+} \mathbf{d}
$$

where $\mathbf{T}^{+}$is the pseudo-inverse of $\mathbf{T}$.

\section{Selective pressures over epochs}

We applied our new approach with genotype data of worldwide populations from 17 publicly available datasets (Table S1). After data cleaning (Materials and Methods), we obtained 2346 individuals and grouped them into six population groups based on their geographic locations (Table S2). We also selected 52 SNPs in 19 genes for analysis due to their association with human pigmentation in published genome-wide association studies (GWAS) or phenotype prediction models (Table S3). We then used Eq. 2 with 31 SNPs not in strong linkage disequilibrium $\left(r^{2}<0.8\right)$ to estimate the total selection differences on human pigmentation (Materials and Methods). The maximum differences were observed between Europeans and the two African populations, while the minimum difference was observed between West and East Africans (Table 1). The estimated 95\% confidence intervals (CI) indicate the difference between East and West Africans, as well as between Oceanians and East Asians, is likely due to genetic drift (Table 1). We further assessed the significance levels of the observed selection differences by randomly sampling 10,000 sets of 31 SNPs in the genome and obtained the empirical distributions of population differences (Fig. 1). The differences from random sets of SNPs were close to zero, whereas those from SNPs associated with human pigmentation were significantly departure from zero (Fig. 1). This suggests that most population differences on SNPs associated with human pigmentation are possibly contributed by natural selection and not confounded by genetic drift. 
Table 1. Selection differences with $95 \%$ CI associated with human pigmentation between

179 populations $\left(\times \mathbf{1 0}^{-3} /\right.$ generation $)$.

\begin{tabular}{ccccccc}
\hline & WAF & EAF & OCN & EUR & NAS & EAS \\
\hline WAF & 0 & -3.527 & -17.402 & -33.992 & -24.397 & -20.052 \\
& & \pm 3.745 & \pm 6.623 & \pm 5.425 & \pm 6.359 & \pm 6.084 \\
EAF & 3.527 & & -17.614 & -38.668 & -26.484 & -20.976 \\
& \pm 3.745 & 0 & \pm 8.391 & \pm 6.900 & \pm 8.085 & \pm 7.753 \\
OCN & 17.402 & 17.614 & & -27.368 & -11.534 & -4.373 \\
& \pm 6.623 & \pm 8.391 & 0 & \pm 8.695 & \pm 9.078 & \pm 8.511 \\
EUR & 33.992 & 38.668 & 27.368 & & 19.793 & 28.747 \\
& \pm 5.425 & \pm 6.900 & \pm 8.695 & 0 & \pm 9.400 & \pm 8.907 \\
NAS & 24.397 & 26.484 & 11.534 & -19.793 & & 11.018 \\
& \pm 6.359 & \pm 8.085 & \pm 9.078 & \pm 9.400 & & \pm 8.741 \\
EAS & 20.052 & 20.976 & 4.373 & -28.747 & -11.018 & \\
& \pm 6.084 & \pm 7.753 & \pm 8.511 & \pm 8.907 & \pm 8.741 & 0 \\
\hline
\end{tabular}

Oceanians; EUR, Europeans; NAS, North Asians; EAS, East Asians. 

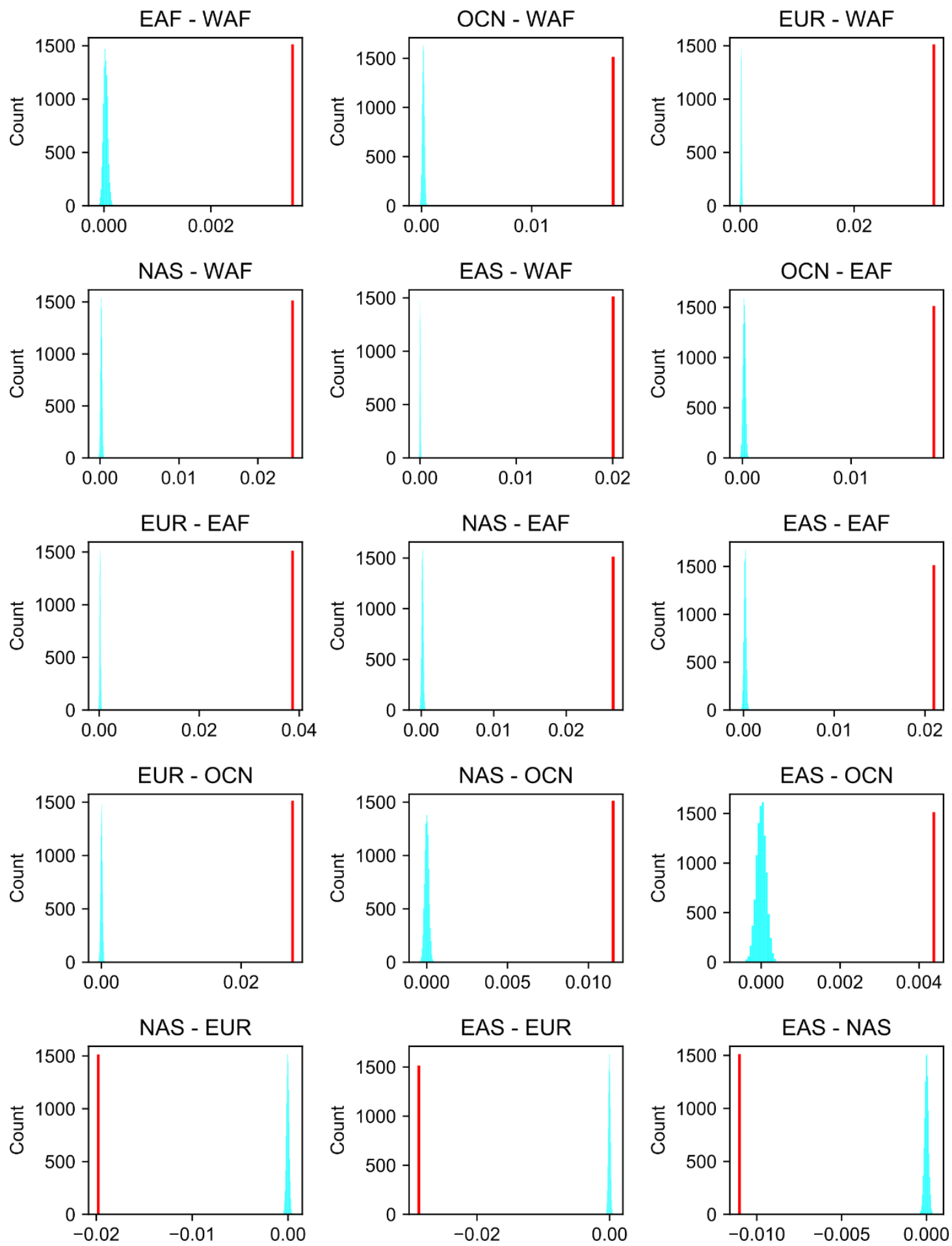

Fig. 2. Significance levels of the selection differences associated with human pigmentation between populations. The blue bars are the empirical distributions of population differences using 10,000 random sets of 31 SNPs in the genomes. The red lines are the selection differences between populations using 31 SNPs associated human pigmentation

187 (Materials and Methods). Population abbreviations: WAF, West Africans; EAF, East Africans; OCN, Oceanians; EUR, Europeans; NAS, North Asians; EAS, East Asians. 
We then solved the linear system (Eq. 4) with the observed selection differences on human pigmentation (Table 1). Our estimate shows that the modern European lineage had the largest selective pressure $\left(s_{4}^{*}=0.0249 /\right.$ generation $)$ on light pigmentation than the other branches (Fig. 1), suggesting that recent natural selection favored light pigmentation in Europeans. Recent studies using ancient DNA could support our observation of recent directional selection in Europeans [18, 41]. Our results also reveal the selective pressure on light pigmentation in the ancestral population of Europeans and East Asians $\left(s_{8}^{*}=0.00665 /\right.$ generation). This shared selection is also supported by other studies, revealing that ASIP, $B N C 2$, and KITLG were under directional selection before the divergence of ancestral Europeans and East Asians [16, 34]. We further applied SLiM 2 [42] to examine whether the optimal solution could reproduce the observed selection differences (Table 1). We set up a human demographic model according to previous studies and used the optimal solution as selection coefficients during different periods (Materials and Methods). The simulated selection differences were close to the data and little affected by the initial frequency of the beneficial allele (Fig. 3). This also illustrates that though we assume genic selection, our model could approximate genotypic selection in diploids (Materials and Methods).

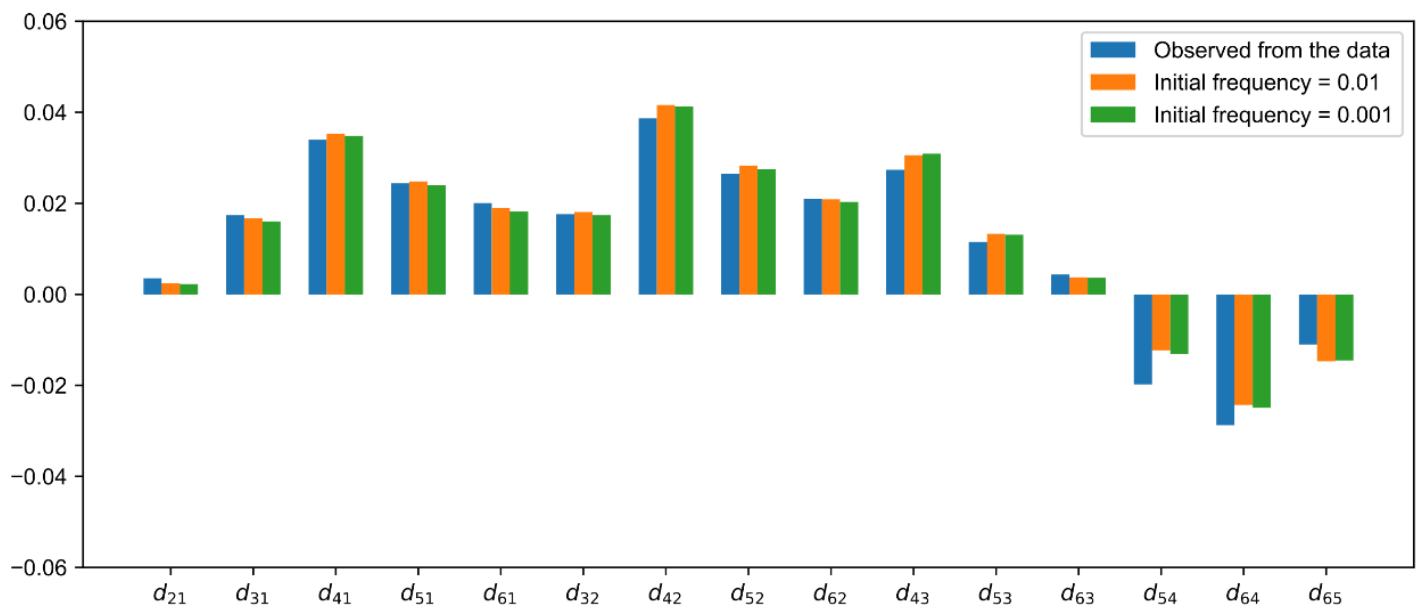

Fig. 3. Comparisons between selection differences from simulation and the data. The selection differences are: $d_{21}$, differences between East Africans and West Africans; $d_{31}$, differences between Oceanians and West Africans; $d_{41}$, differences between Europeans and West Africans; $d_{51}$, differences between North Asians and West Africans; $d_{61}$, differences between East Asians and West Africans; $d_{32}$, differences between Oceanians and East Africans; 
$211 d_{42}$, differences between Europeans and East Africans; $d_{52}$, differences between North Asians

212 and East Africans; $d_{62}$, differences between East Asians and East Africans; $d_{43}$, differences

213 between Europeans and Oceanians; $d_{53}$, differences between North Asians and Oceanians; $d_{63}$, 214 differences between East Asians and Oceanians; $d_{54}$, differences between North Asians and

215 Europeans; $d_{64}$, differences between East Asians and Europeans; $d_{65}$, differences between East 216 Asians and North Asians.

\section{Selection differences between populations}

218 We also separately quantified selection differences of individual SNPs associated with human 219 pigmentation (Table S4) using Eq. 1. Ten SNPs were removed because of their low derived 220 allele frequencies among populations in our data (Materials and Methods). Statistical tests 221 suggest that selective pressures in many loci differed significantly between populations $(p<$ 222 0.05). The remaining 42 SNPs were categorized into five groups (Fig. 4). 


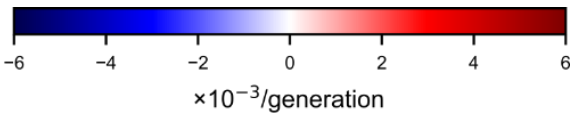

A

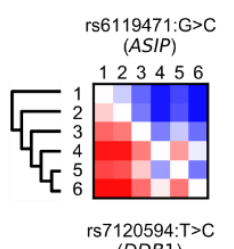

(DDB1)

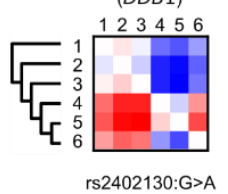

(SLC24A4)
(SL2130:G>A

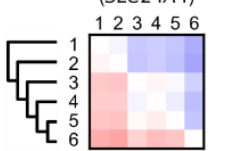

B
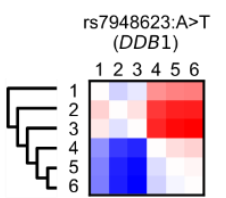

C

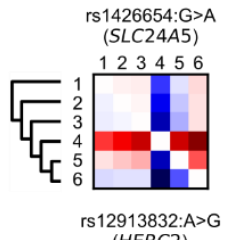
(HERC2)

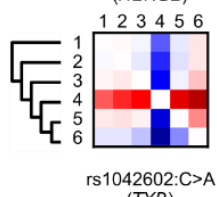

$(T Y R)$

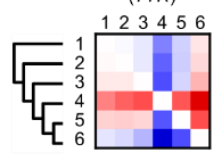

D

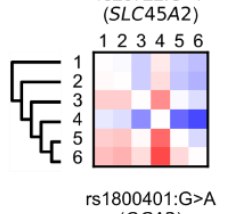

(OCA2)

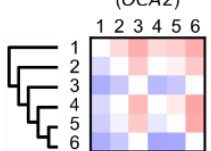

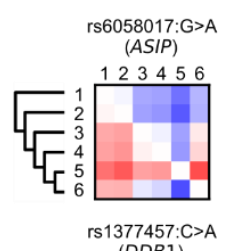

1377457:C>A
(DDB1)
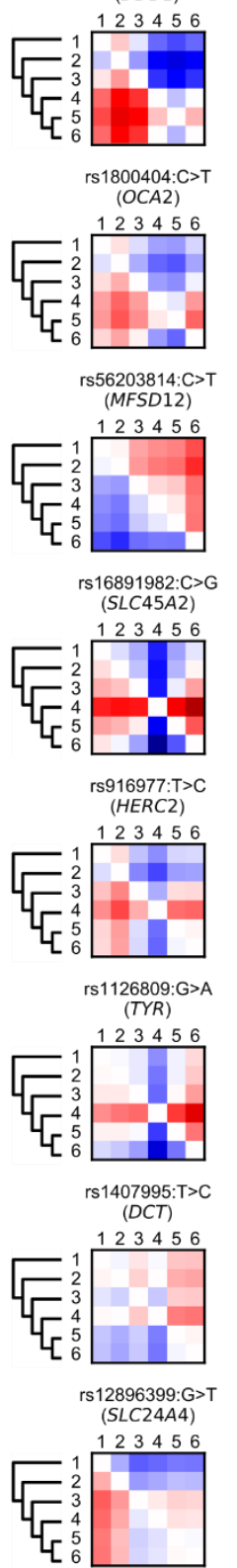
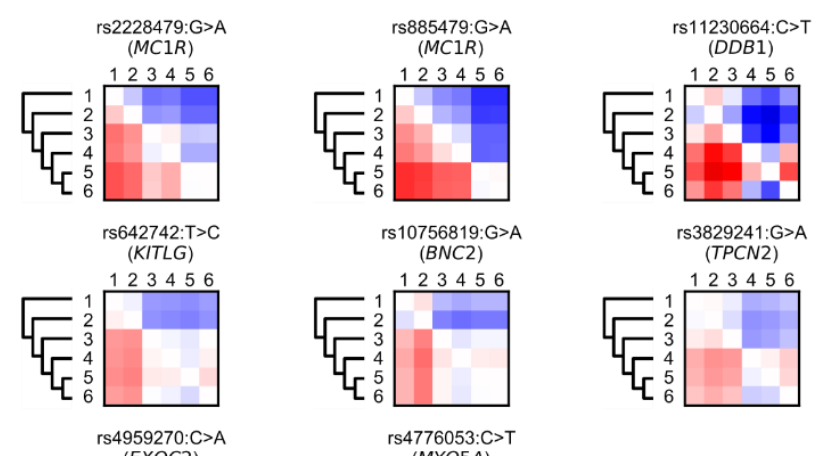

(EXOC2)
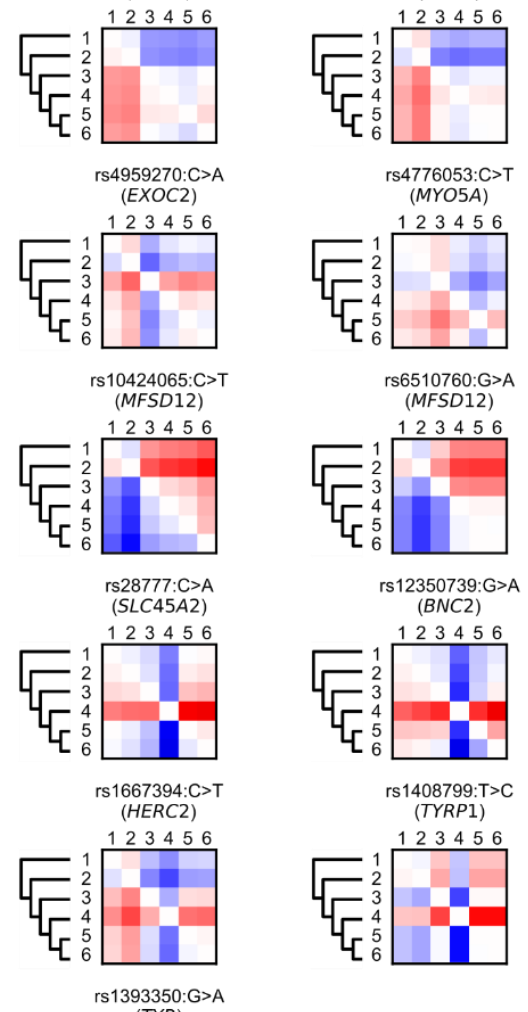

(MFSD12)

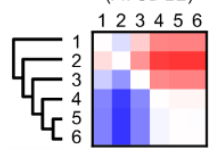

rs12350739:G>A (BNC2)

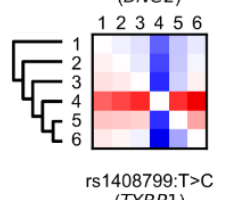

(TYRP1)
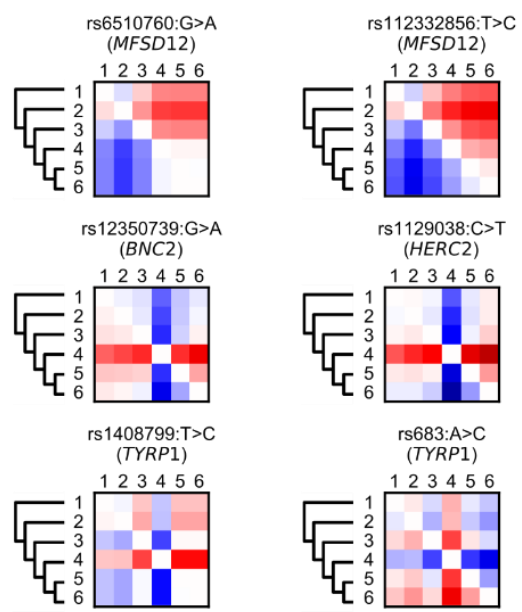

rs683:A>C
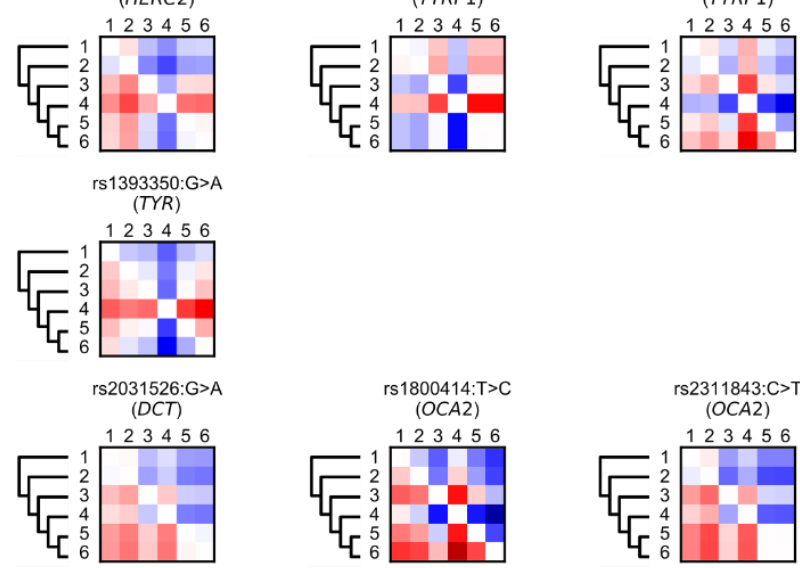

rs35264875:A>T

$($ TPCN2)
123456
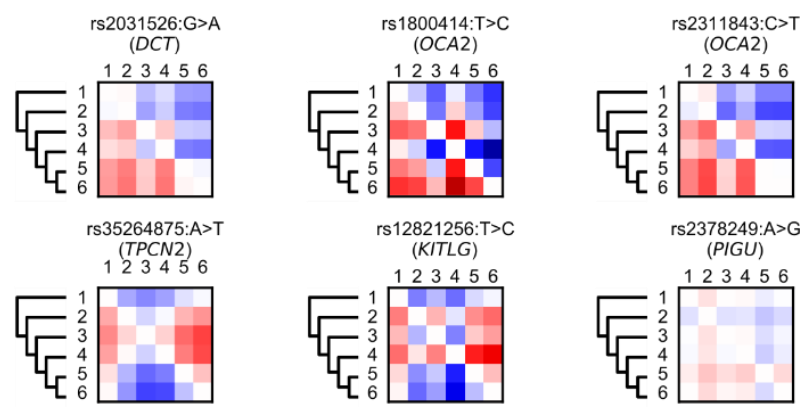

Fig. 4. Selection differences in individual loci between populations. We used Eq. 1 to

quantify the selection differences of 42 SNPs associated with human pigmentation, and categorized them into five kinds of patterns: (A) Derived alleles affected by Eurasian-shared selection; (B) Derived alleles affected by African-specific selection; (C) Alleles affected by 
European-specific selection; (D) Alleles affected by Asian-specific selection; and (E) Others. Red color (positive numbers) indicates selective pressures of populations in rows are larger than those in columns; blue color (negative numbers) indicates selective pressures of populations in rows are smaller than those in columns. Populations are abbreviated as follows: 1, West Africans; 2, East Africans; 3, Oceanians; 4, Europeans; 5, North Asians; 6, East Asians

In the first group, derived alleles may be affected by Eurasian-shared selection (Fig. 4A). Among these SNPs, rs6119471 (ASIP) has large selection difference between Eurasians and Africans (Table S4). The derived allele of rs6119471 (ASIP) is almost fixed across Eurasians but maintains a low frequency in Africans (Fig. S2). Recent studies applied this SNP to predict dark/non-dark pigmentation phenotype in humans [43]. This may be explained by different selective pressures on this SNP among populations. Other SNPs, such as rs642742 (KITLG) and rs10756819 (BNC2), exhibit non-significant differences, suggesting that selection may contribute less to the diversity of these SNPs.

Our results also indicate that two SNPs in MC1R (rs2228479 and rs885479) largely differ between Eurasians and Africans (Table S4). Previous studies used variants in MCIR to solve a long-standing puzzle, regarding whether light pigmentation in low UVR areas is caused by directional selection or the relaxation of selective pressures $[18,44,45]$. The relaxation of selective pressures would suggest that the diversity of $M C 1 R$ variants increased in Eurasians due to the lack of selective constraints. In this scenario, the genetic diversity of $M C 1 R$ variants could be largely attributed to genetic drift. In contrast, directional selection would suggest that $M C 1 R$ variants were under positive selection in Eurasians. In this scenario, genetic drift cannot explain the genetic divergence of $M C 1 R$ between Africans and Eurasians. Our statistical results show that the divergences of rs2228479 and rs885479 between Eurasians and Africans are highly significant departure from neutral evolution (Table S4), suggesting that directional selection is the more likely explanation. Experimental evidence suggests that the derived allele of rs2228479 could cause lower affinity for alpha-melanocyte stimulating hormone than the ancestral allele [46]. Another study showed that the derived allele of rs885479 carries a lower risk of developing freckles and severe solar lentigines than 
the ancestral allele in East Asians [47]. These studies revealed the potential roles of these $M C 1 R$ variants in pigmentation phenotypes.

In the second group, derived alleles may be affected by African-specific selection (Fig. 4B). All these derived alleles are in/near two genes (DDB1 and MFSD12) and were recently associated with human dark pigmentation [48]. The previous study [48] did not find signals of positive selection at MFSD12 using Tajima's D or iHS. Our method [36] show that these SNPs in MFSD12 differ significantly between Africans and Eurasians-possible signals of directional selection (Table S4). From the first and second groups, we can observe that directional selection not only affects derived alleles associated with light pigmentation in Eurasians, but also influences derived alleles associated with dark pigmentation in Africans. This observation suggests that human pigmentation is under directional selection with diversifying orientations among different populations. Thus, the previous view that the dark pigmentation in Africans is the result of purifying selection on ancestral alleles is incomplete [45]. Moreover, these new loci illustrate that we still have little understanding of the genetic diversity within African populations, and more research in this area is needed [49].

The third and fourth groups display European- and Asian-specific selection, respectively (Fig. 4C and 4D). One notable SNP is rs1426654 (SLC24A5), which had the largest selection difference between Europeans and East Asians in our study (0.005774/generation). Previous studies reported that this SNP is under strong directional selection in Europeans [10-15]. Another notable SNP is rs1800414 (OCA2), which had a large selection difference between East Asians and other populations. This reveals a potential role of rs1800414 (OCA2) on light pigmentation in East Asians. Several studies have suggested directional selection on this SNP in East Asians [50, 51]. These large selection differences indicate the significant contributions of these SNPs to light pigmentation in Europeans and East Asians, respectively. Other SNPs in these groups also support the hypothesis that recent natural selection for light pigmentation independently occurred in Europeans and Asians since they diverged [14, 50, 51]. Interestingly, Oceanians comprise both African-specific (DDB1) and Asian-specific (OCA2) selection. However, due to limited sample size of Oceanians in our data from publicly available resources (Table S2), it should be cautious to interpret these results. Thus, it would be helpful to analyze larger datasets of Oceanians to confirm our observation. 
The last group includes the five remaining SNPs (Fig. 4E), which exhibit specific selection differences between limited population pairs. Among them, the derived allele of rs1800401 (OCA2) and the ancestral allele of rs12896399 (SLC24A4) are both associated with dark pigmentation (Table S2). Only rs12896399 (SLC24A4) differs significantly between West Africans and Eurasians (Table S4). This may be a selection signal associated with dark pigmentation in West Africans, again indicating possible genetic diversity within African populations. We note that rs35264875 (TPCN2) and rs12821256 (KITLG) might be affected by selection in both East Africans and Europeans. A recent study showed that rs12821256 might have large effect on the skin pigmentation in South Africans [52]. The other two SNPs, rs3829241 (TPCN2) and rs642742 (KITLG), also differ between Eurasians and Africans (Fig. 4A). These similar patterns of TPCN2 and KITLG might suggest some connection between them.

Compared with previous studies [10-18], our study has three advantages. First, our approach considers the fluctuation of selective pressures that was ignored by previous studies. Our results provide more information about the dynamics of selective pressures during human evolution. Second, we summarize selective pressures based on multiple human pigmentation genes (Eq. 2), while previous studies usually tested selection signals in individual human pigmentation genes. Moreover, we simultaneously interpret selective pressures in multiple populations, whereas previous studies separately investigated selection signals in single population. Third, we do not need to assume population continuity as in those ancient DNA studies [18, 41], because our study is based on genetic data from only present-day populations.

We note that our investigation has several limitations. First, our model is based on the infinite population size model. The limited sample size would affect our results, therefore, we grouped populations into a large population group based on their geographic locations to mitigate the effect of sample size. Analysis of data with larger sample size could improve our estimate, as more and more genomic datasets become available. Second, although we chose the solution that deviates least from neutral evolution as the optimal solution, we cannot exclude the possibility of other solutions. This reflects the difficulty of analyzing historical selective pressures, which is a well-recognized challenge in population genetics [53]. Our 
solution provides a first step toward resolving the dynamics of selection in the evolution of human pigmentation. This solution may be improved by combining both ancient and modern human genetic data, as well as by using a Bayesian framework with varied selection coefficients among loci for inference. Adding more population groups would also possibly improve the solution, because this would provide more constraints in the linear system (Eq. 4). Third, our results may be affected by a severe bottleneck. A recent study [53] suggests a more severe Out-of-Africa bottleneck in human evolutionary history than in the model used in our simulation. This would probably reduce the selection differences between Eurasians and Africans, leading to an underestimation of selective pressures. Fourth, our results may also be affected by population migration and sub-structure. We used knowledge from previous studies, principle component analysis and $F_{3}$ test to rigorously prune potential admixed populations, including South Asians, Central Asians, the Middle East People and Americans. Removing these populations would lose information of selective pressures on human pigmentation in these lineages; however, as a first step to explore the historical selective pressures in the evolution of human pigmentation, we focused more on reducing the bias induced by population admixture. New methods explicitly accounting for population admixture would be helpful to provide more comprehensive view on the dynamics of selective pressures during the evolution of human pigmentation. Besides, we demonstrate that our estimate provides lower bounds of selection differences on human pigmentation when migration or sub-structure exists (Text S1). Finally, our candidate SNPs may be biased. For example, our results indicate small genetic differences on human pigmentation between these two populations (Table 1), while recent studies [52] suggest Oceanians are darker than East Asians in skin pigmentation using melanin index. One possible reason is that some Oceanian-specific or East-Asian-specific SNPs are missing. This is because we selected candidates based on results from published GWAS or phenotype prediction models, and most of these studies used samples with European ancestry [55]. More studies on non-European populations could resolve this missing diversity and enhance our knowledge on the evolution of human pigmentation.

To summarize, we extended an established method [36] to dissect dynamics of selective pressures over epochs. Our study provides the first attempt to resolve time-varied selective 
347 pressures in the evolution of human pigmentation. The fluctuation of selective pressures is an 348 important factor in evolution [53], but few studies have revealed time-varied selective pressures in human populations. Our study also provides information on differences of selective pressures between distinct population groups. Further studies are in progress to verify our present views on the evolution of human pigmentation.

\section{Materials and Methods}

Data preparation

Seventeen datasets $[40,56-71]$ containing genotype data from worldwide human populations were obtained from the listed resources (Table S1). After downloading, all the genotype data were liftovered to genomic coordinates using the Human Reference Genome hg19. A merged dataset containing 6531 individuals was obtained after removing duplicated and related individuals. After merging, SNPs with call rate less than 0.99 or individuals with call rate less than 0.95 were removed. SNPs in strong linkage disequilibrium were further removed by applying a window of 200 SNPs advanced by 25 SNPs and an $r^{2}$ threshold of 0.8 (--indep-pairwise 20025 0.8) in PLINK 1.7 [72]. The remaining 61,597 SNPs were used for further analysis. In order to mitigate the bias induced by population migration, potential admixed populations, such as the Middle East People and South Asians, were excluded according to previous studies [40, 56-71], principal component analysis (PCA) using SMARTPCA (version: 13050) from EIGENSOFT (version: 6.0.1) [73, 74], and $F_{3}$ test using ADMIXTOOLS (version: 3.0) [75]. Finally, 2346 individuals were obtained and divided into six groups according to their geographic regions for further analysis. These groups are West Africans, East Africans, Oceanians, Europeans, North Asians and East Asians. The PCA plot (Fig. S1) shows that these 2346 individuals were properly separated into six population groups. 
371

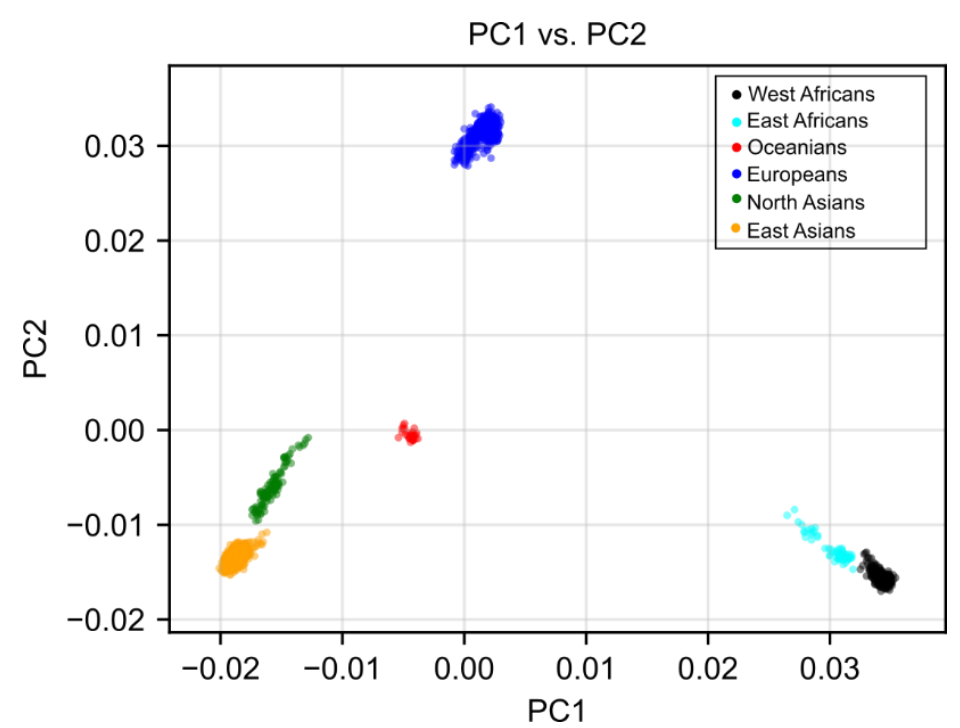

Fig. S1. PCA plots of 2346 samples.

\section{Data imputation}

Genotypes of 19 human pigmentation genes with 500-kb flanking sequences on both sides were obtained from the genotype datasets. Haplotype inference and genotype imputation were performed on the selected genotypes using BEAGLE $4.1[76,77]$ with 1000 Genomes phase 3 haplotypes as the reference panel. During phasing and imputation, the effective population size was assumed to be $10,000\left(N_{e}=10000\right)$, and the other parameters were set to the default values. Ten SNPs (rs1110400, rs11547464, rs12203592, rs1800407, rs1805005, rs1805006, rs1805007, rs1805008, rs1805009, rs74653330) were removed because of their low derived allele frequencies in our datasets after imputation (Fig. S2). Because rs12203592 (IRF4) was removed, 18 genes with the remaining 42 SNPs were used for further analysis. 

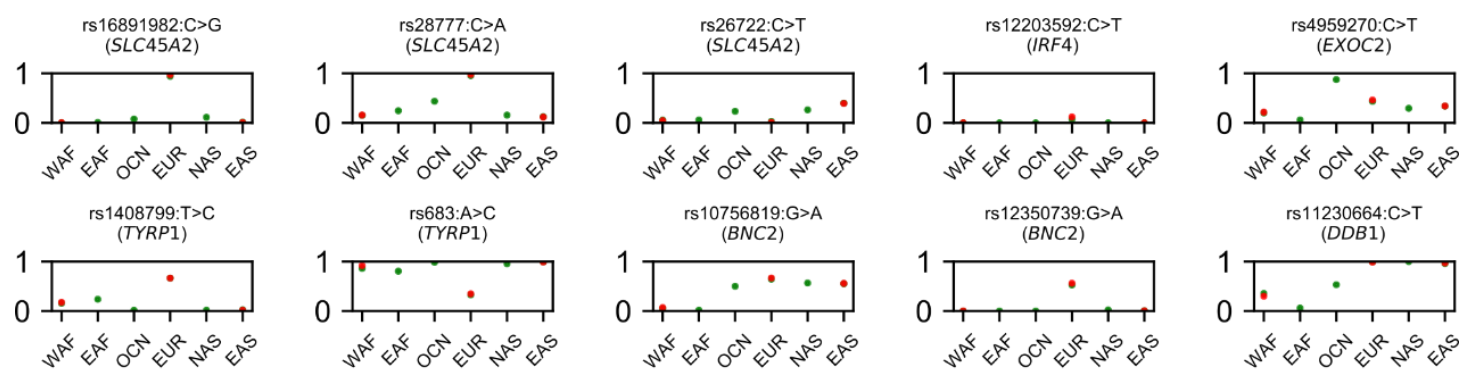

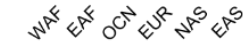

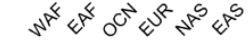

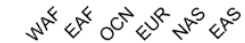
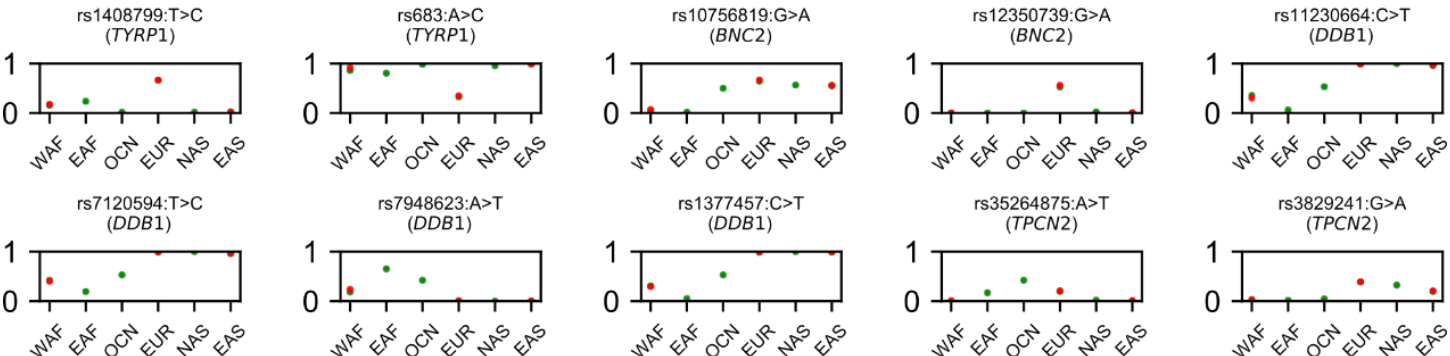

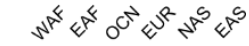

rs 1042602:C $>A$
$(T Y R)$

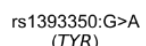

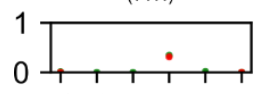

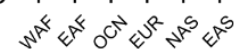

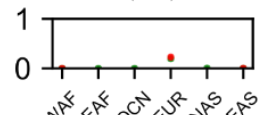

rs1126809:G>A

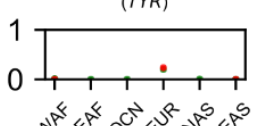

rs642742:A>G
(KITLG)
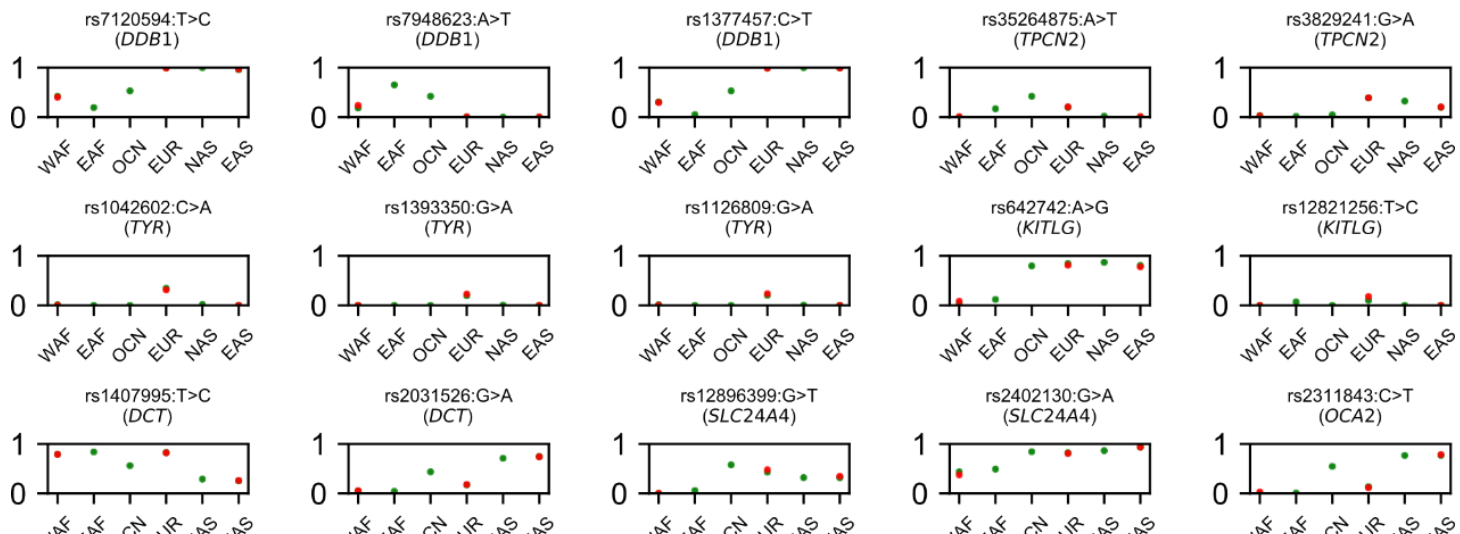

rs2031526:G>A

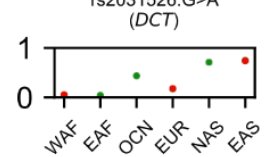

rs12896399:G>T

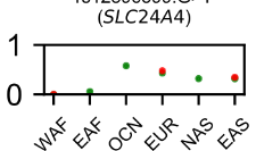

rs2402130:G>A

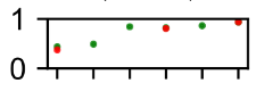

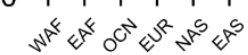

$$
\begin{gathered}
\text { rs1800414:A>G } \\
(O C A 2)
\end{gathered}
$$

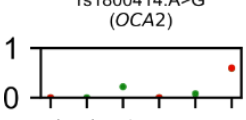

s74653330:G>A
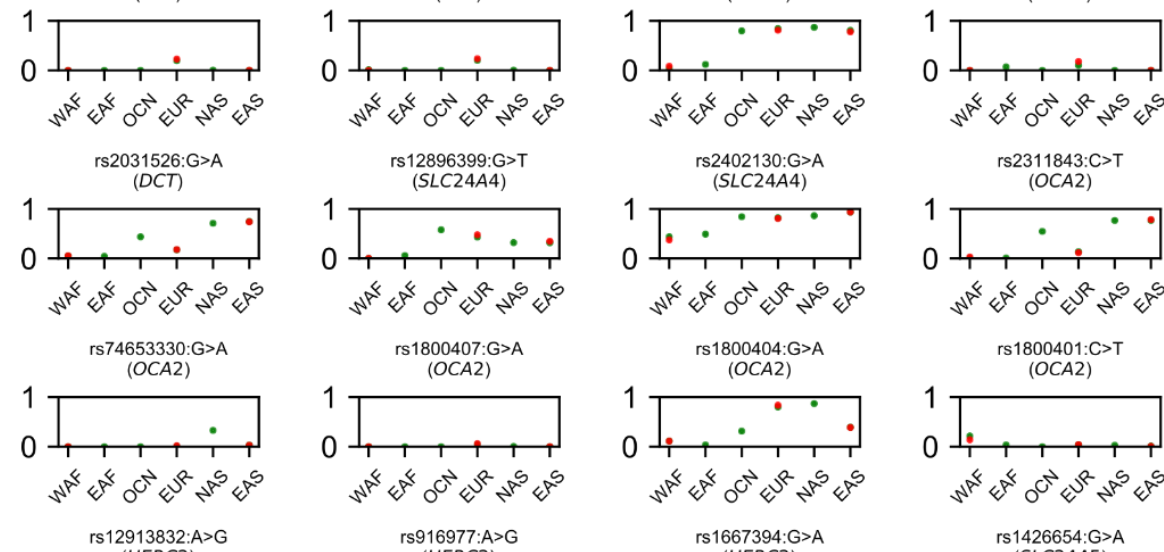

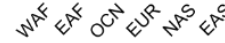

rs12913832:A>G
(HERC2)
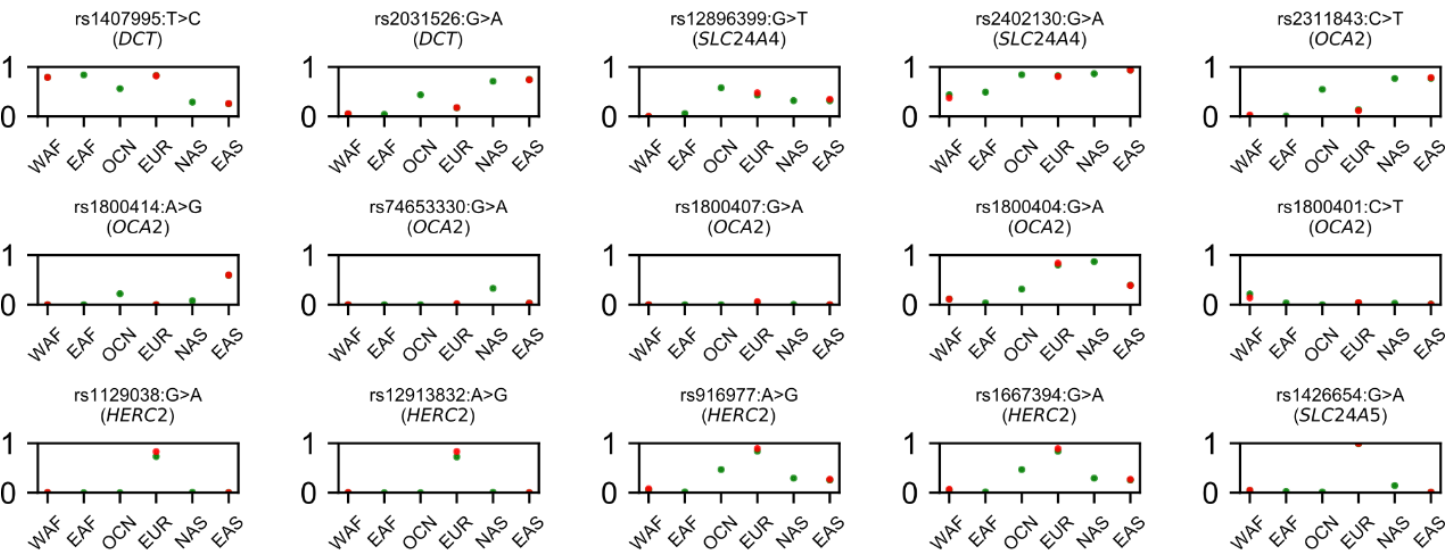

rs4776053:C>T

rs1805005:G>T

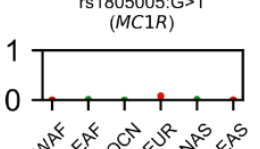

rs 1805006:C>A
$(M C 1 R)$

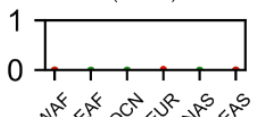

rs2228479:G $>A$
$(M C 1 R)$
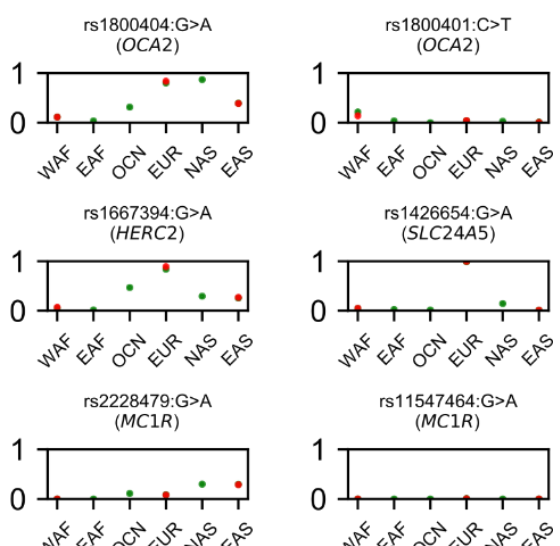

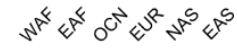

rs 1426654:G>A

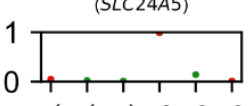

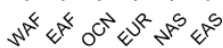

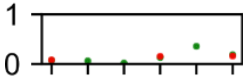

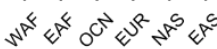

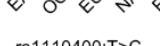

rs1805007:C>

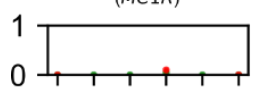

1110400:T>
$(M C 1 R)$

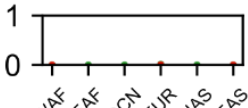

rs1805008:C>T

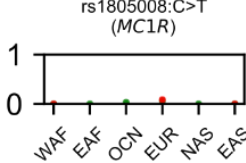

rs885479:G>A

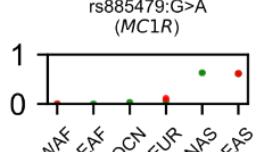

rs11547464:G>A
$(M C 1 R)$

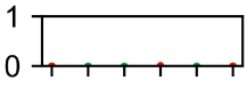

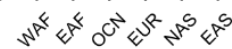

rs1805009:G>C

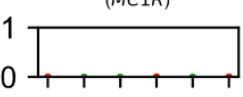

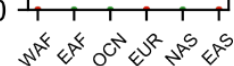
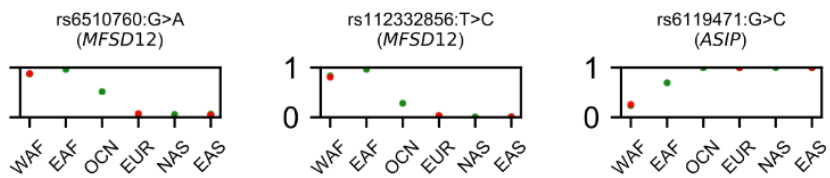

3.

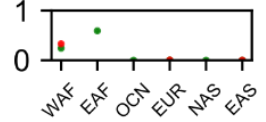

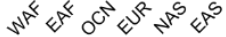

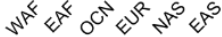

vite
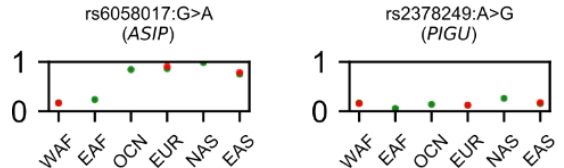

- Derived allele frequencies from the 1000 Genomes project

- Derived allele frequencies from imputation

Fig. S2. Derived allele frequencies of candidate SNPs from imputation and the 1000

Genomes project. Population abbreviations: WAF, West Africans; EAF, East Africans; OCN,

Oceanians; EUR, Europeans; NAS, North Asians; EAS, East Asians. 
388 We used Eq. 1 to estimate the selection differences of the remaining 42 SNPs. We then used 389 Eq. 2 and selected 31 SNPs not in strong linkage disequilibrium $\left(r^{2}<0.8\right)$ as well as known phenotypes to estimate the total selection differences on human pigmentation between populations. These SNPs were: rs3829241, rs56203814, rs916977, rs1800414, rs10424065, rs6119471, rs1408799, rs11230664, rs1407995, rs4959270, rs1800401, rs2378249, rs1042602, rs12350739, rs6058017, rs12821256, rs1393350, rs1426654, rs642742, rs6510760, rs1129038, rs2228479, rs35264875, rs12896399, rs26722, rs16891982, rs885479, rs28777, rs1800404, rs10756819, rs2402130. To dissect selective pressures over epochs, we applied Eq. 4 with the total selection differences from the selected 31 SNPs and the divergence times shown in Fig.

397

398 1.

\section{Reproducing the observed selection differences from the optimal solution}

We used SLiM 2 (version: 2.6) [42] to simulate a demographic model of human evolution (Fig. S3) to examine whether the optimal solution could reproduce the observed selection differences. We varied the initial frequency of the beneficial allele with 0.001 and 0.01 . We divided the optimal solution by 31 to obtain the average selection coefficient for each SNP, because we used 31 SNPs to estimate the total selection differences on human pigmentation (Text S2). We used the effective population size of each population estimated by previous studies [78, 79]. We set both the mutation rate and the recombination rate to $1 \times$ $10^{-8} /$ generation/site. In each run, we simulated a fragment with $10^{6}$ base pairs, and set the 50,000 th site under selection. We repeated each set of parameters more than 10,000 times, and analyzed those results in which beneficial alleles were not fixed or lost in all the populations. We compared the average selection differences from simulation with the observed selection differences.

All the simulations were performed in Digital Ocean (https://cloud.digitalocean.com/) Optimized Droplets. The information of these droplets is as follows: CPU, Intel ${ }^{\circledR}$ Xeon ${ }^{\circledR}$ Platinum 8168 Processor; Random-access memory, 64 GB; Operating system, Ubuntu 16.04.4 x64. 


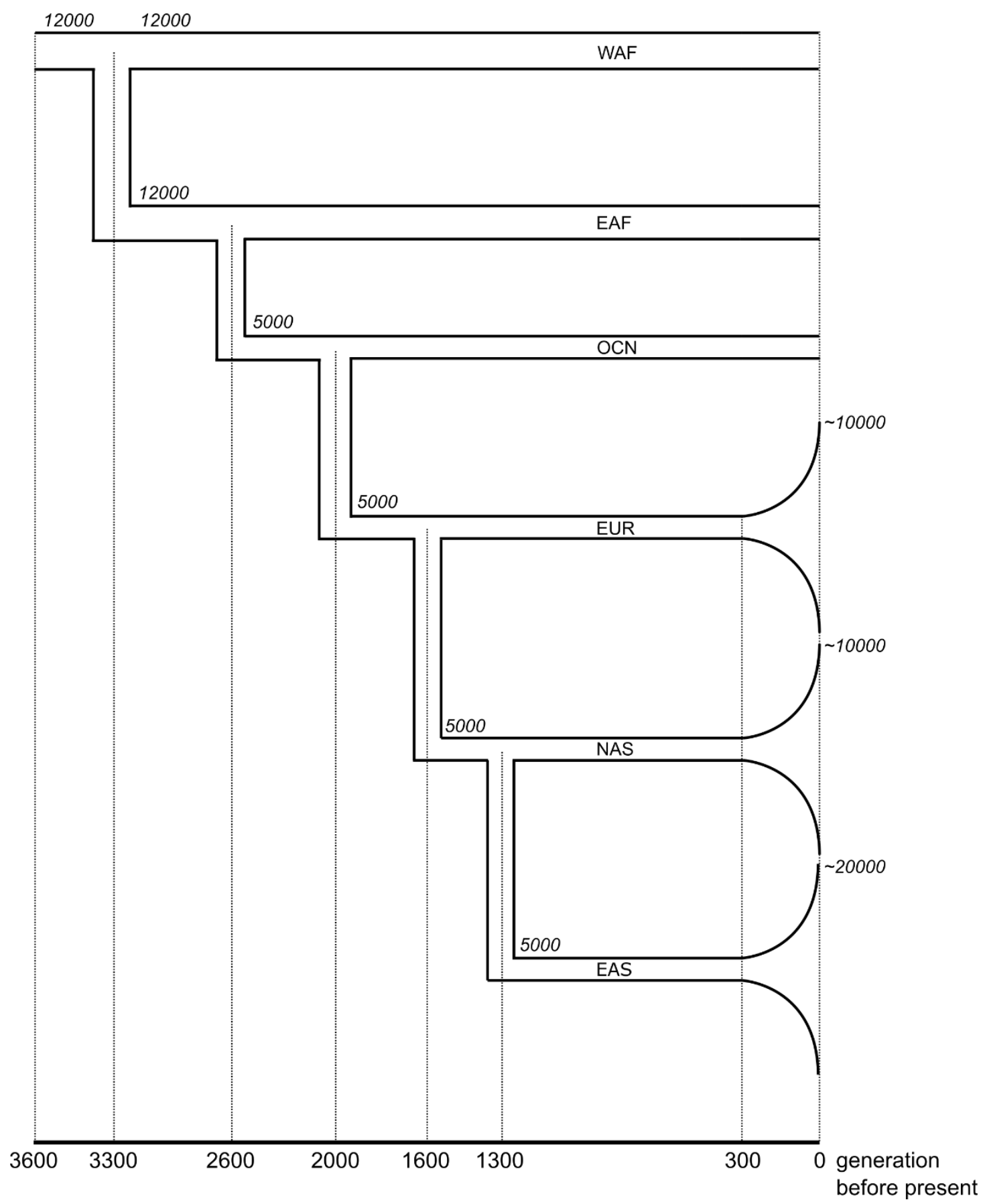

Fig. S3. The demography model for simulation. The italic numbers indicate population sizes at different time periods. Population abbreviations: WAF, West Africans; EAF, East Africans; OCN, Oceanians; EUR, Europeans; NAS, North Asians; EAS, East Asians.

We noticed that the selection coefficient in SLiM 2 measures differences in fitness 420 between genotypes instead of alleles. We can transform the selection coefficient of genotypes 421 into that of alleles as follows. Let the fitness of the ancestral allele $A$ be 1 , and the relative 422 fitness of the derived allele $a$ is $e^{s}$. When $s$ is close to 0 , we can approximate $e^{s}$ as $1+s$ using 
the Taylor series. The fitness of genotype $a a$ becomes $(1+s)^{2}=1+2 s+s^{2} \approx 1+2 s$, and the fitness of genotype $A a$ is $1+s=1+0.5 s^{\prime}$. If $s^{\prime}$ is the selection coefficient in SLiM 2, then $s^{\prime}$ $=2 s ;$ and the dominance coefficient becomes 0.5 .

\section{Supporting Information}

S1 Table. Data resources.

\section{S2 Table. Population information.}

S3 Table. Candidate SNPs.

S4 Table. Selection differences on the selected 42 SNPs.

S1 Fig. PCA plots of 2346 samples.

S2 Fig. Derived allele frequencies of candidate SNPs from imputation and the 1000

Genomes project. Population abbreviations: WAF, West Africans; EAF, East Africans; OCN, Oceanians; EUR, Europeans; NAS, North Asians; EAS, East Asians.

S3 Fig. The demography model for simulation. The italic numbers indicate population sizes at different time periods. Population abbreviations: WAF, West Africans; EAF, East Africans; OCN, Oceanians; EUR, Europeans; NAS, North Asians; EAS, East Asians.

\section{S1 Text. The effects of migration and substructure.}

\section{S2 Text. A sample script for simulation with SLiM 2.}

\section{Acknowledgements}

This work was supported by grants from National Natural Science Foundation of China (91331109 to Y.H.; 31271338 and 31330038 to L.J.; 31322030 and 91331108 to S.W.). Y.H. is also grateful for support from the SA-SIBS scholarship program and the Youth Innovation Promotion Association of Chinese Academy of Science (2012216). L.J. was also supported by the Shanghai Leading Academic Discipline Project (B111) and the Center for Evolutionary Biology at Fudan University. S.W. was also awarded by the National Thousand Young Talents Award, the Max Planck-CAS Paul Gerson Unna Independent Research Group Leadership Award, and open projects from the State Key Laboratory of Genetic Engineering at Fudan University. X.H. is grateful to Dr. Minxian Wang, Dr. Yuchen Wang, Dr. Haiyi Lou and Dr. Lin Tang for comments on the manuscript.

\section{Author Contribution}


452 X.H. and Y.H. designed the study. X.H. collected and simulated the data. X.H. and Y.H.

453 developed the model, analyzed the data and wrote the manuscript. S.W. and L.J. revised the 454 manuscript.

\section{$455 \quad$ References}

456 1. Darwin C. 1889. The descent of man, and selection in relation to sex. New York: D.

$457 \quad$ Appleton and Company.

458

459

460

461

462

463

2. Norton HL. 2005. Human skin pigmentation variation: a phenotypic, genotypic and evolutionary perspective. Ph.D. Dissertation, Pennsylvania State University. Available from https://etda.libraries.psu.edu/catalog/6658

3. Rees JL, Harding RM. Understanding the evolution of human pigmentation: Recent contributions from population genetics. J Invest Dermatol. 2012; 132: 846-853.

4. Barsh GS. What controls variation in human skin color? PLoS Biol. 2003; 1: 19-22.

5. Jablonski NG, Chaplin G. The evolution of human skin coloration. J Hum Evol. 2000; 39: $57-106$.

6. Parra EJ. Human pigmentation variation: evolution, genetic basis, and implications for public health. Am J Phys Anthropol. 2007; Suppl 45: 85-105.

7. Jablonski NG, Chaplin G. The colours of humanity: the evolution of pigmentation in the human lineage. Phil Trans R Soc B 2017; 372: 20160349.

8. Cuthill IC, Allen WL, Arbuckle K, Caspers B, Chaplin G, Hauber ME, et al. The biology of color. Science 2017; 357: eaan0221.

9. Hochberg Z, Hochberg I. Evolutionary perspective in rickets and vitamin D. Front Endocrinol. 2019; 10: 306. doi: 10.3389/fendo.2019.00306

10. Izagirre N, García I, Junquera C, de la Rúa C, Alonso S. A scan for signatures of positive selection in candidate loci for skin pigmentation in humans. Mol Biol Evol. 2006; 23: $1697-1706$.

11. Voight BF, Kudaravalli S, Wen X, Pritchard JK. A map of recent positive selection in the human genome. PLoS Biol. 2006; 5: e147. 
12. Lao O, de Gruijter JM, van Duijin K, Navarro A, Kayser M. Signatures of positive selection in genes associated with human skin pigmentation as revealed from analyses of single nucleotide polymorphisms. Ann Hum Genet. 2007; 71: 354-369.

13. Myles S, Somel M, Tang K, Kelso J, Stoneking M. Identifying genes underlying skin pigmentation differences among human populations. Hum Genet. 2007; 120: 613-621.

14. Norton HL, Kittles RA, Parra E, McKeigue P, Mao X, Cheng K, et al. Genetic evidence for the convergent evolution of light skin in Europeans and East Asians. Mol Biol Evol. 2007; 24: 710-722.

15. Pickrell J, Coop G, Novermbre J, Kudaravalli S, Li JZ, Absher D, et al. Signals of recent positive selection in a worldwide sample of human populations. Genome Res. 2009; 19: $826-837$.

16. Beleza S, Santos AM, McEvoy B, Alves I, Martinho C, Cameron E, et al. The timing of pigmentation lightening in Europeans. Mol Biol Evol. 2013; 30: 24-35.

17. Hider JL, Gittelman RM, Shah T, Edwards M, Rosenbloom A, Akey JM, et al. Exploring signatures of positive selection in pigmentation candidate genes in populations of East Asian ancestry. BMC Evol Biol. 2013; 13: 150.

18. Wilde S, Timpson A, Kirsanow K, Kaiser E, Kayser M, Unterländer M, et al. Direct evidence for positive selection of skin, hair, and eye pigmentation in Europeans during the last 5,000 y. Proc Natl Acad Sci USA 2014; 111: 4832-4837.

19. Abdel-Malek ZA, Scott MC, Furumura M, Lamoreux ML, Ollmann M, Barsh GS, et al. The melanocortin 1 receptor is the principal mediator of the effects of agouti signaling protein on mammalian melanocytes. J Cell Biol. 2010; 114: 1019-1024.

20. Rebbeck TR, Kanetsky PA, Walker AH, Holmes R, Halpern AC, Schuchter LM, et al. P gene as an inherited biomarker of human eye color. Cancer Epidem Biomar. 2002; 11: $782-784$.

21. Duffy DL, Box NF, Chen W, Palmer JS, Montgomery GW, James MR, et al. Interactive effects of MC1R and OCA2 on melanoma risk phenotypes. Hum Mol Genet. 2004; 13 : $447-461$. 
22. Duffy DL, Montgomery GW, Chen W, Zhao ZZ, Le L, James MR, et al. A three-single-nucleotide polymorphism haplotype in intron 1 of $O C A 2$ explains most human eye-color variation. Am J Hum Genet. 2007; 80: 241-252.

23. Graf J, Hodgson R, van Daal A. Single nucleotide polymorphisms in the MATP gene are associated with normal human pigmentation variation. Hum Mutat. 2005; 25: 278-284.

24. Sulem P, Gudbjartsson DF, Stacey SN, Helgason A, Rafnar T, Magnusson KP, et al. Genetic determinants of hair, eye and skin pigmentation in Europeans. Nat Genet. 2007; 39: $1443-1452$.

25. Sulem P, Gudbjartsson DF, Stacey SN, Helgason A, Rafnar T, Jakobsdottir M, et al. Two newly identified genetic determinants of pigmentation in Europeans. Nat Genet. 2008; 40: $835-837$.

26. Anno S, Abe T, Yamamoto T. Interactions between SNP alleles at multiple loci contribute to skin color differences between Caucasoid and Mongoloid subjects. Int J Biol Sci. 2008; 4: $81-86$.

27. Han J, Kraft P, Nan H, Guo Q, Chen C, Qureshi A, et al. A genome-wide association study identifies novel alleles associated with hair color and skin pigmentation. PLoS Genet. 2008; 4: e1000074.

28. Ito S, Wakamatsu K. Chemistry of mixed melanogenesis - pivotal roles of dopaquinone. Photochem Photobiol. 2008; 84: 582-592.

29. Kayser M, Liu F, Janssens AC, Rivadeneira F, Lao O, van Duijn K, et al. Three genome-wide association studies and a linkage analysis identify $H E R C 2$ as a human iris color gene. Am J Hum Genet. 2008; 82: 411-423.

30. Sturm RA, Duffy DL. Human pigmentation genes under environmental selection. Genome Biol. 2012; 13: 248.

31. Visser M, Kayser M, Palstra R. HERC2 rs12913832 modulates human pigmentation by attenuating chromatin-loop formation between a long-range enhance and the OCA2 promoter. Genome Res. 2012; 22: 446-455.

32. Visser M, Palstra R, Kayser M. Human skin color is influenced by an intergenic DNA polymorphism regulating transcription of the nearly $B N C 2$ pigmentation gene. Hum Mol Genet. 2014; 23: 5750-5762. 
33. Guenther CA, Tasic B, Luo L, Bedell MA, Kingsley DM. A molecular basis for classic blond hair color in Europeans. Nat Genet. 2014; 46: 748-754.

34. McEvoy B, Beleza S, Shriver MD. The genetic architecture of normal variation in human pigmentation: an evolutionary perspective and model. Hum Mol Genet. 2006; 15: R176-R181.

35. Donnelly MP, Paschou P, Grigorenko E, Gurwitz D, Barta C, Lu RB, et al. A global view of the OCA2-HERC2 region and pigmentation. Hum Genet. 2012; 131: 683-696.

36. He Y, Wang M, Huang X, Li R, Xu H, Xu S, et al. A probabilistic method for testing and estimating selection differences between populations. Genome Res. 2015; 25: 1903-1909.

37. Schaffner SF, Foo C, Gabriel S, Reich D, Daly MJ, Altshuler D. Calibrating a coalescent simulation of human genome sequence variation. Genome Res. 2005; 15: 1576-1583.

38. Oppenheimer S. 2012. Out-of-Africa, the peopling of continents and islands: tracing uniparental gene trees across the map. Phil Trans R Soc B. 367: 770-784.

39. Schiffel S, Durbin R. Inferring human population size and separation history from multiple genome sequences. Nat Genet. 2014; 46: 919-925.

40. Modal M, Casals F, Xu T, Dall'Olio GM, Pybus M, Netea MG, et al. Genomic analysis of Andamanese provides insights into ancient human migration into Asia and adaptation. Nat Genet. 2016; 48: 1066-1070.

41. Mathieson I, Lazaridis I, Rohland N, Mallick S, Patterson N, Roodenberg SA, et al. Genome-wide patterns of selection in 230 ancient Eurasians. Nature 2015; 528: 499-503.

42. Haller BC, Messer PW. SLiM 2: Flexible, interactive forward genetic simulations. Mol Biol Evol. 2017; 34: 230-240.

43. Spichenok O, Budimlija ZM, Mitchell AA, Jenny A, Kovacevic L, Marjanovic D, et al. Prediction of eye and skin color in diverse populations using seven SNPs. Forensic Sci Int Gen. 2011; 5: 472-478.

44. Rana BK, Hewett-Emmett D, Jin L, Chang BH, Sambuughin N, Lin M, et al. High polymorphism at the human melanocortin 1 receptor locus. Genetics 1999; 151: $1547-1557$.

45. Harding RM, Healy E, Ray AJ, Ellis NS, Flanagan N, Todd C, et al. Evidence for variable selective pressures at MC1R. Am J Hum Genet. 2000; 66: 1351-1361. 
46. Xu X, Thörnwall M, Lundin L, Chhajlani V. Val92Met variant of the melanocyte stimulating hormone receptor gene. Nat Genet. 1996; 14: 384.

47. Motokawa T, Kato T, Hashimoto Y, Katagiri T. Effect of Val92Met and Arg163Gln variants of the $M C 1 R$ gene on freckles and solar lentigines in Japanese. Pigment Cell Res. 2007; 20: 140-143.

48. Crawfold NG, Kelly DE, Hansen MEB, Beltrame MH, Fan S, Bowman BL, et al. Loci associated with skin pigmentation identified in African populations. Science 2017; 358: eaan8433.

49. Lasisi T, Shriver MD. Focus on African diversity confirms complexity of skin pigmentation genetics. Genome Biol. 2018; 19: 13.

50. Edwards M, Bigham A, Tan J, Li S, Gozdzik A, Ross K, et al. Association of the OCA2 polymorphism His615Arg with melanin content in East Asian Populations: further evidence of convergent evolution of skin pigmentation. PLoS Genet. 2010; 6: e1000867.

51. Yang Z, Zhong H, Chen J, Zhang X, Zhang H, Luo X, et al. A genetic mechanism for convergent skin lightening during recent human evolution. Mol Biol Evol. 2016; 33: $1177-1187$.

52. Martin AR, Lin M, Granka JM, Myyrick JW, Liu X, Sockell A, et al. An unexpectedly complex architecture for skin pigmentation in Africans. Cell 2017; 171: 1340-1353.

53. Crow JF, Kimura M. 2009. An introduction to population genetics theory. Caldwell: The Blackburn Press.

54. Terhorst J, Kamm JA, Song YS. Robust and scalable inference of population history from hundreds of unphased whole genomes. Nat Genet. 2017; 49: 303-309.

55. Sirugo G, Williams SM, Tishkoff SA. The missing diversity in human genetic studies. Cell 2019; 177: 26-31.

56. Li JZ, Absher DM, Tang H, Southwick AM, Casto AM, Ramachandran S, et al. Worldwide human relationships inferred from genome-wide patterns of variation. Science 2008; 319: 1100-1104.

57. Behar DM, Yunusbayev B, Metsplau M, Metsplau E, Rosset S, Parik J, et al. The genome-wide structure of the Jewish people. Nature 2010; 466: 238-242. 
58. Cristofaro JD, Pennarun E, Mazières S, Myres NM, Lin AA, Temori SA, et al. Afghan Hindu Kush: where Eurasian sub-continent gene flows converge. PLoS One 2013; 8: e76748.

59. Fedorova SA, Reidla M, Metspalu E, Metspalu M, Rootsi S, Tambets K, et al. 2013. Autosomal and uniparental portraits of the native populations of Sakha (Yakutia): implications for the peopling of Northeast Eurasia. BMC Evol Biol. 2013; 13: 127.

60. Kovacevic L, Tambets K, Ilumäe AM, Kushniarevich A, Yunusbayev B, Solnik A, et al. Standing at the gateway to Europe - the genetic structure of Western Balkan populations based on autosomal and haploid markers. PLoS One 2014; 9: e105090.

61. Metspalu M, Romero IG, Yunusbayev B, Chaubey G, Mallick CB, Hudjashov G, et al. Shared and unique components of human population structure and genome-wide signals of positive selection in South Asia. Am J Hum Genet. 2011; 89: 731-744.

62. Pagani L, Kivisild T, Tarekegn A, Ekong R, Plaster C, Gallego Romero I, et al. Ethiopian genetic diversity reveals linguistic stratification and complex influences on the Ethiopian gene pool. Am J Hum Genet. 2012; 91: 83-96.

63. Raghavan M, Skoglund P, Graf KE, Metspalu M, Albrechtsen A, Moltke I, et al. 2014. Upper Paleolithic Siberian genome reveals dual ancestry of Native Americans. Nature 2014; 505: 87-91.

64. Rasmussen M, Li Y, Lindgreen S, Pedersen JS, Albrechtsen A, Moltke I, et al. Ancient human genome sequence of an extinct Palaeo-Eskimo. Nature 2010; 463: 757-762.

65. Teo YY, Sim X, Ong RTH, Tan AKS, Chen J, Tantoso E, et al. Singapore genome variation project: a haplotype map of three Southeast Asian populations. Genome Res. 2009; 19: 2154-2162.

66. The 1000 Genomes Project Consortium. A map of human genome variation from population-scale sequencing. Nature 2010; 467: 1061-1073.

67. The International HapMap 3 Consortium. Integrating common and rare genetic variation in diverse human populations. Nature 2010; 467: 52-58.

68. Xing J, Wuren T, Simonson TS, Watkins WS, Witherspoon D, Wu W, et al. Genomic analysis of natural selection and phenotypic variation in high-altitude Mongolians. PLoS Genet. 2013; 9: e1003634. 
69. Yunusbayev B, Metspalu M, Järve M, Kutuev I, Rootsi S, Metspalu E, et al. The Caucasus as an asymmetric semipermeable barrier to ancient human migrations. Mol Biol Evol. 2012; 29: 359-365.

70. Yunusbayev B, Metspalu M, Metspalu E, Valeev, A., Litvinov S, Valiev R, et al. The genetic legacy of the expansion of Turkic-speaking nomads across Eurasia. PLoS Genet. 2015; 11: e1005068.

71. Pagani L, Lawson DJ, Jagoda E, Morseburg A, Eriksson A, Mitt M, et al. Genomic analyses inform on migration events during the peopling of Eurasia. Nature 2016; 538: $238-242$.

72. Purcell S, Neale B, Todd-Brown K, Thomas L, Ferreira MA, Bender D, et al. 2007. PLINK: a toolset for whole-genome association and population-based linkage analysis. Am J Hum Genet. 2007; 81: 559-575.

73. Patterson N, Price AL, Reich D. 2006. Population structure and eigenanalysis. PLoS Genet. 2006; 2: e190.

74. Price AL, Patterson NJ, Plenge RM, Weinblatt ME, Shadick NA, Reich D. Principal components analysis corrects for stratification in genome-wide association studies. Nat Genet. 2006; 38: 904-909.

75. Patterson N, Moorjani P, Luo Y, Mallick S, Rohland N, Zhang Y, et al. 2012. Ancient admixture in human history. Genetics 2012; 192: 1065-1093.

76. Browning BL, Browning SR. Genotype imputation with millions of reference samples. Am J Hum Genet. 2016; 98: 116-126.

77. Browning SR, Browning BL. Rapid and accurate haplotype phasing and missing data inference for whole genome association studies by use of localized haplotype clustering. Am J Hum Genet. 2007; 81: 1084-1097.

78. McEvoy BP, Powell JE, Goddard ME, Visscher PM. Human population dispersal "Out of Africa" estimated from linkage disequilibrium and allele frequencies of SNPs. Genome Res. 2011; 21: 821-829.

79. Mezzavilla M, Ghirotto S. Neon: An R package to estimate human effective population size and divergence time from patterns of linkage disequilibrium between SNPs. J Comput Sci Syst Biol. 2015; 8: 37-44. 
80. Walsh S, Liu F, Wollstein A, Kovatsi L, Ralf A, Kosiniak-Kamysz A, et al. The HIrisPlex system for simultaneous prediction of hair and eye colour from DNA. Forensic Sci Int Genet 2013; 7: 98-115.

81. Praetorius C, Grill C, Stacey SN, Metcalf AM, Gorkin DU, Robinson KC, et al. A polymorphism in IRF4 affects human pigmentation through a tyrosinase-dependent MITF/TFAP2A pathway. Cell 2013; 155: 1022-1033.

82. Jacobs LC, Wollstein A, Lao O, Hofman A, Klaver CC, Uitterlinden AG, et al. Comprehensive candidate gene study highlights UGT1A and BNC2 as new genes determining continuous skin color variation in Europeans. Hum Genet. 2013; 132: $147-158$.

83. Stokowki RP, Pant PV, Dadd T, Fereday A, Hinds DA, Jarman C, et al. A genomewide association study of skin pigmentation in a South Asian population. Am J Hum Genet. 2007; 81: 1119-1132.

84. Miller CT, Beleza S, Pollen AA, Schluter D, Kittles RA, Shriver MD, et al. cis-Regulatory changes in Kit ligand expression and parallel evolution of pigmentation in stickebacks and humans. Cell 2007; 131: 1179-1189.

85. Murray N, Norton HL, Parra EJ. Distribution of two OCA2 polymorphisms associated with pigmentation in East-Asian populations. Hum Genome Var 2015; 2: 15058.

86. Branicki W, Brudnik U, Wojas-Pelc A. Interactions between HERC2, OCA2 and MC1R may influence human pigmentation phenotype. Ann Hum Genet. 2009; 73: 160-170.

87. Branicki W, Liu F, van Duijin K, Draus-Barini J, Pośpiech E, Walsh S, et al. Model-based prediction of human hair color using DNA variants. Hum Genet. 2011; 129: 443-454.

88. Eiberg H, Troelsen J, Nielsen M, Mikkelsen A, Mengel-From J, Kjaer KW, et al. Blue eye color in humans may be caused by a perfectly associated founder mutation in a regulatory element located within the HERC2 gene inhibiting OCA2 expression. Hum Genet. 2008; 123: 177-187.

89. Sturm RA, Duffy DL, Zhao ZZ, Leite FP, Stark MS, Hayward NK, et al. A single SNP in an evolutionary conserved region within intron 86 of the HERC2 gene determines human blue-brown eye color. Am J Hum Genet. 2008; 82: 424-431. 
90. Lamason RL, Mohideen MA, Mest JR, Wong AC, Norton HL, Aros MC, et al. SLC24A5, a putative cation exchanger, affects pigmentation in zebrafish and humans. Science 2005; 310: $1782-1786$.

689

91. Hart KL, Kimura SL, Mushailov V, Budimlijia ZM, Prinz M, Wurmbach E. Improved eye- and skin-color prediction based on 8 SNPs. Croat Med J. 2013; 54: 248-256.

691

92. Bonilla C, Boxill LA, Donald SA, Williams T, Sylvester N, Parra EJ, et al. The $8818 \mathrm{G}$

692 allele of the agouti signaling protein (ASIP) gene is ancestral and is associated with darker skin color in African Americans. Hum Genet. 2005; 116: 402-406. 
Table S1 Data resources

\begin{tabular}{|c|c|c|c|}
\hline Dataset & Sample & Resource & Reference \\
\hline $1 \mathrm{KG}$ & 2504 & http://www.1000genomes.org/ & 66 \\
\hline HapMap3 & 1397 & http://www.sanger.ac.uk/resources/downloads/human/hapmap3.html & 67 \\
\hline Jew & 466 & http://evolbio.ut.ee/jew/ & 57 \\
\hline Afghan & 24 & http://evolbio.ut.ee/afghan/ & 58 \\
\hline Sakha & 40 & http://evolbio.ut.ee/sakha/ & 59 \\
\hline Balkan & 70 & http://evolbio.ut.ee/balkan/ & 60 \\
\hline HGDP & 1043 & ftp://ftp.cephb.fr/hgdp_supp1/ & 56 \\
\hline India & 142 & http://evolbio.ut.ee/india/ & 61 \\
\hline Ethiopian & 235 & http://mega.bioanth.cam.ac.uk/data/Ethiopia & 62 \\
\hline Malta & 85 & http://evolbio.ut.ee/malta/ & 63 \\
\hline Saqqaq & 197 & http://evolbio.ut.ee/saqqaq/ & 64 \\
\hline SGVP & 268 & http://phg.nus.edu.sg/StatGen/public_html/SGVP/download.html & 65 \\
\hline NorthernEurasian & 369 & Request from the authors & 68 \\
\hline Caucasus & 204 & http://evolbio.ut.ee/caucasus/ & 69 \\
\hline Turkic & 322 & http://evolbio.ut.ee/turkic/ & 70 \\
\hline Andamanese & 10 & https://www.ebi.ac.uk/ena/data/view/PRJEB11455 & 40 \\
\hline EGDP & 483 & http://evolbio.ut.ee/CGgenomes.html & 71 \\
\hline
\end{tabular}


Table S2 Population information

\begin{tabular}{|c|c|c|c|}
\hline Data resource & Population group & Population abbreviation & Sample size \\
\hline Ethiopian & East Africans & ANU & 21 \\
\hline Ethiopian & East Africans & GUM & 15 \\
\hline Ethiopian & East Africans & SUD & 23 \\
\hline $1 \mathrm{KG}$ & East Asians & $\mathrm{CHN}$ & 208 \\
\hline $1 \mathrm{KG}$ & East Asians & DAI & 93 \\
\hline $1 \mathrm{KG}$ & East Asians & JAP & 104 \\
\hline $1 \mathrm{KG}$ & East Asians & KHV & 96 \\
\hline EGDP & East Asians & BUM & 1 \\
\hline EGDP & East Asians & DSN & 8 \\
\hline EGDP & East Asians & IGO & 8 \\
\hline EGDP & East Asians & LBO & 4 \\
\hline EGDP & East Asians & LUZ & 2 \\
\hline EGDP & East Asians & MUR & 8 \\
\hline EGDP & East Asians & VIZ & 2 \\
\hline EGDP & East Asians & VTN & 10 \\
\hline HapMap3 & East Asians & $\mathrm{CHN}$ & 152 \\
\hline HapMap3 & East Asians & JAP & 16 \\
\hline HGDP & East Asians & $\mathrm{CHN}$ & 44 \\
\hline HGDP & East Asians & DAI & 10 \\
\hline HGDP & East Asians & JAP & 28 \\
\hline HGDP & East Asians & LAH & 8 \\
\hline HGDP & East Asians & MIA & 10 \\
\hline HGDP & East Asians & NAX & 9 \\
\hline HGDP & East Asians & SHE & 10 \\
\hline HGDP & East Asians & TUJ & 10 \\
\hline HGDP & East Asians & YIZ & 10 \\
\hline SGVP & East Asians & $\mathrm{CHN}$ & 96 \\
\hline $1 \mathrm{KG}$ & Europeans & CEU & 99 \\
\hline $1 \mathrm{KG}$ & Europeans & FIN & 99 \\
\hline $1 \mathrm{KG}$ & Europeans & GBR & 91 \\
\hline Jew & Europeans & BEL & 9 \\
\hline Jew & Europeans & $\mathrm{HNG}$ & 20 \\
\hline Jew & Europeans & LIT & 10 \\
\hline Jew & Europeans & $\mathrm{RMN}$ & 14 \\
\hline Jew & Europeans & RUS & 2 \\
\hline EGDP & Europeans & ALB & 3 \\
\hline EGDP & Europeans & BEL & 4 \\
\hline EGDP & Europeans & $\mathrm{COS}$ & 4 \\
\hline EGDP & Europeans & $\mathrm{CRO}$ & 4 \\
\hline EGDP & Europeans & EST & 6 \\
\hline
\end{tabular}




\begin{tabular}{|c|c|c|c|}
\hline EGDP & Europeans & FIN & 3 \\
\hline EGDP & Europeans & GER & 3 \\
\hline EGDP & Europeans & $\mathrm{HNG}$ & 2 \\
\hline EGDP & Europeans & ING & 3 \\
\hline EGDP & Europeans & KAR & 3 \\
\hline EGDP & Europeans & KOM & 2 \\
\hline EGDP & Europeans & LAT & 3 \\
\hline EGDP & Europeans & LIT & 3 \\
\hline EGDP & Europeans & MOL & 2 \\
\hline EGDP & Europeans & MRD & 3 \\
\hline EGDP & Europeans & POL & 4 \\
\hline EGDP & Europeans & RUS & 7 \\
\hline EGDP & Europeans & SWE & 2 \\
\hline EGDP & Europeans & UKR & 7 \\
\hline EGDP & Europeans & VEP & 4 \\
\hline HapMap3 & Europeans & CEU & 24 \\
\hline Balkan & Europeans & BOS & 14 \\
\hline Balkan & Europeans & KSV & 9 \\
\hline Balkan & Europeans & MAC & 14 \\
\hline Balkan & Europeans & MNT & 14 \\
\hline Balkan & Europeans & SER & 18 \\
\hline HGDP & Europeans & FRE & 28 \\
\hline HGDP & Europeans & ORC & 15 \\
\hline HGDP & Europeans & RUS & 25 \\
\hline Malta & Europeans & EST & 14 \\
\hline Malta & Europeans & RUS & 1 \\
\hline NorthernEurasian & Europeans & SLV & 25 \\
\hline Turkic & Europeans & GAG & 12 \\
\hline Turkic & Europeans & GER & 13 \\
\hline Turkic & Europeans & KAR & 15 \\
\hline Turkic & Europeans & RUS & 33 \\
\hline Turkic & Europeans & VEP & 11 \\
\hline EGDP & North Asians & EVK & 13 \\
\hline EGDP & North Asians & EVN & 8 \\
\hline EGDP & North Asians & NGA & 2 \\
\hline EGDP & North Asians & SAK & 7 \\
\hline EGDP & North Asians & YAK & 1 \\
\hline Sakha & North Asians & DOL & 3 \\
\hline Sakha & North Asians & EVN & 8 \\
\hline Sakha & North Asians & YAK & 1 \\
\hline HGDP & North Asians & YAK & 22 \\
\hline Malta & North Asians & DOL & 1 \\
\hline
\end{tabular}




\begin{tabular}{cccc} 
Malta & North Asians & EVE & 2 \\
Saqqaq & North Asians & DOL & 4 \\
Saqqaq & North Asians & EVE & 15 \\
Saqqaq & North Asians & NGA & 13 \\
Saqqaq & North Asians & YUK & 3 \\
Turkic & North Asians & EVE & 3 \\
Turkic & North Asians & EVN & 3 \\
Turkic & North Asians & NGA & 2 \\
Turkic & North Asians & YAK & 3 \\
EGDP & Oceanians & KOI & 3 \\
EGDP & Oceanians & KOS & 3 \\
HGDP & Oceanians & PAP & 16 \\
Andamanese & Oceanians & AND & 10 \\
1 KG & West Africans & ESN & 99 \\
1 KG & West Africans & GWD & 112 \\
1 KG & West Africans & MSL & 85 \\
1 KG & West Africans & YOR & 108 \\
HapMap3 & West Africans & YOR & 46 \\
HGDP & West Africans & MND & 22 \\
HGDP & West Africans & YOR & 21 \\
\hline
\end{tabular}

696 
Table S3 Candidate SNP information

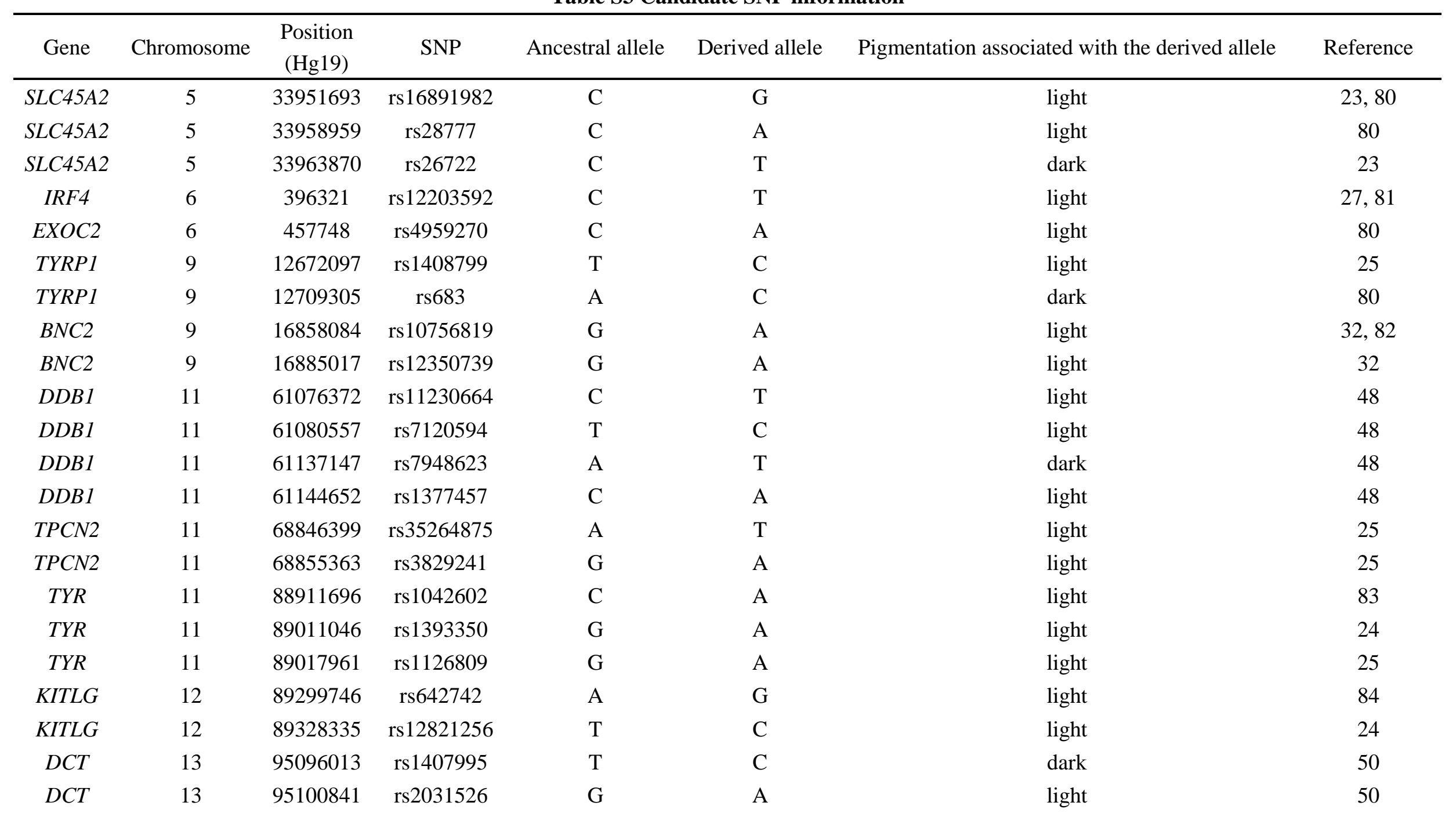




\begin{tabular}{|c|c|c|c|c|c|c|c|}
\hline SLC24A4 & 14 & 92773663 & rs12896399 & $\mathrm{G}$ & $\mathrm{T}$ & light & 24 \\
\hline$S L C 24 A 4$ & 14 & 92801203 & rs2402130 & $\mathrm{G}$ & A & light & 80 \\
\hline$O C A 2$ & 15 & 28183354 & rs2311843 & $\mathrm{C}$ & $\mathrm{T}$ & Unknown & 26 \\
\hline OCA2 & 15 & 28197037 & rs1800414 & A & G & light & $50,51,85$ \\
\hline OCA2 & 15 & 28228553 & rs74653330 & $\mathrm{G}$ & A & light & 85 \\
\hline$O C A 2$ & 15 & 28230318 & rs1800407 & $\mathrm{G}$ & A & light & 86,87 \\
\hline$O C A 2$ & 15 & 28235773 & rs1800404 & $\mathrm{G}$ & A & light & 48 \\
\hline$O C A 2$ & 15 & 28260053 & rs1800401 & $\mathrm{C}$ & $\mathrm{T}$ & dark & 20 \\
\hline HERC2 & 15 & 28356859 & rs1129038 & $\mathrm{G}$ & $\mathrm{A}$ & light & 35,88 \\
\hline HERC2 & 15 & 28365618 & rs12913832 & A & $\mathrm{G}$ & light & 25,89 \\
\hline HERC2 & 15 & 28513364 & rs916977 & $\mathrm{A}$ & $\mathrm{G}$ & light & 29,35 \\
\hline HERC2 & 15 & 28530182 & rs1667394 & G & A & light & 24,35 \\
\hline$S L C 24 A 5$ & 15 & 48426484 & rs1426654 & $\mathrm{G}$ & A & light & 90 \\
\hline MYO5A & 15 & 52816195 & rs4776053 & $\mathrm{C}$ & $\mathrm{T}$ & Unknown & 26 \\
\hline$M C 1 R$ & 16 & 89985844 & rs1805005 & $\mathrm{G}$ & $\mathrm{T}$ & light & 80 \\
\hline$M C 1 R$ & 16 & 89985918 & rs1805006 & $\mathrm{C}$ & $\mathrm{A}$ & light & 80 \\
\hline$M C 1 R$ & 16 & 89985940 & rs2228479 & G & A & light & 80 \\
\hline$M C 1 R$ & 16 & 89986091 & rs11547464 & $\mathrm{G}$ & A & light & 80 \\
\hline$M C 1 R$ & 16 & 89986117 & rs1805007 & $\mathrm{C}$ & $\mathrm{T}$ & light & 80 \\
\hline$M C 1 R$ & 16 & 89986130 & rs1110400 & $\mathrm{T}$ & $\mathrm{C}$ & light & 80 \\
\hline$M C 1 R$ & 16 & 89986144 & rs1805008 & $\mathrm{C}$ & $\mathrm{T}$ & light & 80 \\
\hline$M C 1 R$ & 16 & 89986154 & rs885479 & $\mathrm{G}$ & A & light & 80 \\
\hline$M C 1 R$ & 16 & 89986546 & rs1805009 & $\mathrm{G}$ & $\mathrm{C}$ & light & 80 \\
\hline MFSD12 & 19 & 3544892 & rs56203814 & $\mathrm{C}$ & $\mathrm{T}$ & dark & 48 \\
\hline MFSD12 & 19 & 3545022 & rs 10424065 & $\mathrm{C}$ & $\mathrm{T}$ & dark & 48 \\
\hline
\end{tabular}




\begin{tabular}{cccccccc} 
MFSD12 & 19 & 3565253 & rs6510760 & G & A & dark & dark \\
MFSD12 & 19 & 3565599 & rs112332856 & T & C & C & light \\
ASIP & 20 & 32785212 & rs6119471 & G & A & light \\
ASIP & 20 & 32856998 & rs6058017 & G & G & light \\
PIGU & 20 & 33218090 & rs2378249 & A & G & 91 \\
\hline
\end{tabular}

697

698 
Table S4 Selection differences on the $\mathbf{4 2}$ selected SNPs

\begin{tabular}{|c|c|c|c|c|c|c|c|c|}
\hline Gene & SNP ID & $\begin{array}{l}\text { Ancestral } \\
\text { allele }\end{array}$ & $\begin{array}{l}\text { Derived } \\
\text { allele }\end{array}$ & Population1 & Population2 & $\begin{array}{c}\text { Selection difference } \\
\text { (Population1 - Population2) }\end{array}$ & Std & $p$-value \\
\hline SLC45A2 & rs16891982 & $\mathrm{C}$ & G & Europeans & NorthAsians & 0.003181 & 7.47E-04 & 2.10E-05 \\
\hline SLC45A2 & rs28777 & $\mathrm{C}$ & A & Europeans & NorthAsians & 0.003107 & $7.46 \mathrm{E}-04$ & 3.10E-05 \\
\hline EXOC2 & rs4959270 & $\mathrm{C}$ & A & Europeans & NorthAsians & $4.12 \mathrm{E}-04$ & 7.38E-04 & 0.576675 \\
\hline TYRP1 & rs1408799 & $\mathrm{T}$ & $\mathrm{C}$ & Europeans & NorthAsians & 0.00287 & $7.90 \mathrm{E}-04$ & 2.82E-04 \\
\hline TYRPI & rs683 & A & $\mathrm{C}$ & Europeans & NorthAsians & -0.002354 & $7.60 \mathrm{E}-04$ & 0.001943 \\
\hline$B N C 2$ & rs 12350739 & G & A & Europeans & NorthAsians & 0.002475 & $7.85 \mathrm{E}-04$ & 0.00161 \\
\hline$D D B 1$ & rs11230664 & $\mathrm{C}$ & $\mathrm{T}$ & Europeans & NorthAsians & $-8.56 \mathrm{E}-04$ & 0.001162 & 0.461178 \\
\hline$D D B 1$ & rs7120594 & $\mathrm{T}$ & $\mathrm{C}$ & Europeans & NorthAsians & $-5.17 \mathrm{E}-04$ & 0.001172 & 0.658962 \\
\hline$D D B 1$ & rs7948623 & A & $\mathrm{T}$ & Europeans & NorthAsians & $4.21 \mathrm{E}-04$ & 0.001176 & 0.720668 \\
\hline$D D B 1$ & rs1377457 & $\mathrm{C}$ & A & Europeans & NorthAsians & $-7.42 \mathrm{E}-04$ & 0.001165 & 0.524412 \\
\hline TPCN2 & rs 35264875 & A & $\mathrm{T}$ & Europeans & NorthAsians & 0.00152 & $7.85 \mathrm{E}-04$ & 0.052919 \\
\hline$T Y R$ & rs1126809 & G & A & Europeans & NorthAsians & 0.002329 & 8.94E-04 & 0.009156 \\
\hline KITLG & rs642742 & A & G & Europeans & NorthAsians & $-1.94 \mathrm{E}-04$ & 7.43E-04 & 0.794378 \\
\hline$K I T L G$ & rs12821256 & $\mathrm{T}$ & $\mathrm{C}$ & Europeans & NorthAsians & 0.002653 & 0.001149 & 0.020951 \\
\hline$D C T$ & rs1407995 & $\mathrm{T}$ & $\mathrm{C}$ & Europeans & NorthAsians & 0.001528 & 7.38E-04 & 0.038476 \\
\hline$D C T$ & rs2031526 & G & A & Europeans & NorthAsians & -0.001525 & $7.38 \mathrm{E}-04$ & 0.038867 \\
\hline$S L C 24 A 4$ & rs12896399 & G & $\mathrm{T}$ & Europeans & NorthAsians & $3.51 \mathrm{E}-04$ & 7.38E-04 & 0.634377 \\
\hline$S L C 24 A 4$ & rs 2402130 & G & A & Europeans & NorthAsians & $-2.25 \mathrm{E}-04$ & 7.43E-04 & 0.761965 \\
\hline
\end{tabular}




\begin{tabular}{|c|c|c|c|c|c|c|c|c|}
\hline$O C A 2$ & rs2311843 & $\mathrm{C}$ & $\mathrm{T}$ & Europeans & NorthAsians & -0.001944 & 7.40E-04 & 0.008596 \\
\hline$O C A 2$ & rs1800414 & A & G & Europeans & NorthAsians & -0.002739 & $9.05 \mathrm{E}-04$ & 0.002475 \\
\hline OCA2 & rs1800404 & $\mathrm{C}$ & $\mathrm{T}$ & Europeans & NorthAsians & $-2.52 \mathrm{E}-04$ & 7.43E-04 & 0.73489 \\
\hline$O C A 2$ & rs1800401 & $\mathrm{C}$ & A & Europeans & NorthAsians & $2.58 \mathrm{E}-04$ & 7.81E-04 & 0.741106 \\
\hline HERC2 & rs1129038 & G & A & Europeans & NorthAsians & 0.003579 & 8.33E-04 & 1.80E-05 \\
\hline HERC2 & rs12913832 & A & G & Europeans & NorthAsians & 0.003566 & 8.33E-04 & $1.90 \mathrm{E}-05$ \\
\hline HERC2 & rs916977 & A & G & Europeans & NorthAsians & 0.001695 & 7.39E-04 & $\mathbf{0 . 0 2 1 7 7}$ \\
\hline$H E R C 2$ & rs1667394 & G & A & Europeans & NorthAsians & 0.001684 & 7.39E-04 & 0.022651 \\
\hline$S L C 24 A 5$ & rs1426654 & G & A & Europeans & NorthAsians & 0.004135 & 7.65E-04 & 0 \\
\hline MYO5A & rs4776053 & $\mathrm{C}$ & $\mathrm{T}$ & Europeans & NorthAsians & $-7.63 \mathrm{E}-04$ & 7.38E-04 & 0.301197 \\
\hline$M C 1 R$ & rs2228479 & G & A & Europeans & NorthAsians & $-9.75 \mathrm{E}-04$ & $7.40 \mathrm{E}-04$ & 0.187511 \\
\hline$M C 1 R$ & rs885479 & G & A & Europeans & NorthAsians & -0.001829 & 7.39E-04 & 0.013324 \\
\hline MFSD12 & rs56203814 & $\mathrm{C}$ & $\mathrm{T}$ & Europeans & NorthAsians & $2.40 \mathrm{E}-04$ & 0.001185 & 0.839641 \\
\hline MFSD 12 & rs 10424065 & $\mathrm{C}$ & $\mathrm{T}$ & Europeans & NorthAsians & $2.40 \mathrm{E}-04$ & 0.001185 & 0.839641 \\
\hline MFSD 12 & rs6510760 & G & A & Europeans & NorthAsians & $1.39 \mathrm{E}-04$ & $7.58 \mathrm{E}-04$ & 0.85424 \\
\hline$M F S D 12$ & rs112332856 & $\mathrm{T}$ & $\mathrm{C}$ & Europeans & NorthAsians & $9.48 \mathrm{E}-04$ & 8.98E-04 & 0.291189 \\
\hline$A S I P$ & rs6119471 & G & $\mathrm{C}$ & Europeans & NorthAsians & 0.001135 & 0.001449 & 0.433361 \\
\hline$A S I P$ & rs6058017 & G & A & Europeans & NorthAsians & -0.001192 & 7.91E-04 & 0.132079 \\
\hline$P I G U$ & rs2378249 & A & G & Europeans & NorthAsians & $-5.74 \mathrm{E}-04$ & 7.39E-04 & 0.437671 \\
\hline SLC45A2 & rs16891982 & $\mathrm{C}$ & G & Europeans & Oceanians & 0.002754 & $6.98 \mathrm{E}-04$ & 8.00E-05 \\
\hline SLC45A2 & rs28777 & $\mathrm{C}$ & A & Europeans & Oceanians & 0.001774 & $6.71 \mathrm{E}-04$ & 0.008209 \\
\hline SLC45A2 & rs 26722 & $\mathrm{C}$ & $\mathrm{T}$ & Europeans & Oceanians & -0.001337 & $6.78 \mathrm{E}-04$ & 0.048735 \\
\hline EXOC2 & rs4959270 & $\mathrm{C}$ & A & Europeans & Oceanians & -0.001082 & $6.83 \mathrm{E}-04$ & 0.113007 \\
\hline TYRPI & rs1408799 & $\mathrm{T}$ & $\mathrm{C}$ & Europeans & Oceanians & 0.002211 & 7.75E-04 & 0.00434 \\
\hline$T Y R P 1$ & rs683 & A & $\mathrm{C}$ & Europeans & Oceanians & -0.002211 & $7.75 \mathrm{E}-04$ & 0.00434 \\
\hline$B N C 2$ & rs 10756819 & G & A & Europeans & Oceanians & $3.18 \mathrm{E}-04$ & $6.68 \mathrm{E}-04$ & 0.633414 \\
\hline
\end{tabular}




\begin{tabular}{|c|c|c|c|c|c|c|c|c|}
\hline$B N C 2$ & rs 12350739 & G & A & Europeans & Oceanians & 0.002508 & $9.67 \mathrm{E}-04$ & 0.009475 \\
\hline$D D B 1$ & rs11230664 & $\mathrm{C}$ & $\mathrm{T}$ & Europeans & Oceanians & 0.002313 & $6.83 \mathrm{E}-04$ & 7.03E-04 \\
\hline$D D B 1$ & rs7120594 & $\mathrm{T}$ & $\mathrm{C}$ & Europeans & Oceanians & 0.002585 & 6.94E-04 & $1.94 \mathrm{E}-04$ \\
\hline$D D B 1$ & rs7948623 & A & $\mathrm{T}$ & Europeans & Oceanians & -0.002567 & $6.98 \mathrm{E}-04$ & $2.36 \mathrm{E}-04$ \\
\hline$D D B 1$ & rs1377457 & $\mathrm{C}$ & A & Europeans & Oceanians & 0.002405 & $6.86 \mathrm{E}-04$ & 4.53E-04 \\
\hline TPCN2 & rs 35264875 & A & $\mathrm{T}$ & Europeans & Oceanians & $-5.25 \mathrm{E}-04$ & $6.68 \mathrm{E}-04$ & 0.431752 \\
\hline TPCN2 & rs3829241 & G & A & Europeans & Oceanians & 0.001206 & 7.11E-04 & 0.090003 \\
\hline$T Y R$ & rs1042602 & $\mathrm{C}$ & A & Europeans & Oceanians & 0.002074 & $9.67 \mathrm{E}-04$ & 0.031884 \\
\hline$T Y R$ & rs1393350 & G & A & Europeans & Oceanians & 0.001756 & $9.67 \mathrm{E}-04$ & 0.069267 \\
\hline$T Y R$ & rs1126809 & G & A & Europeans & Oceanians & 0.00178 & 9.67E-04 & 0.065616 \\
\hline KITLG & rs642742 & A & G & Europeans & Oceanians & $1.05 \mathrm{E}-04$ & $6.74 \mathrm{E}-04$ & 0.876062 \\
\hline KITLG & rs 12821256 & $\mathrm{~T}$ & $\mathrm{C}$ & Europeans & Oceanians & 0.001487 & 9.67E-04 & 0.124028 \\
\hline$D C T$ & rs1407995 & $\mathrm{T}$ & $\mathrm{C}$ & Europeans & Oceanians & $6.48 \mathrm{E}-04$ & $6.68 \mathrm{E}-04$ & 0.332199 \\
\hline$D C T$ & rs2031526 & G & A & Europeans & Oceanians & $-6.46 \mathrm{E}-04$ & $6.68 \mathrm{E}-04$ & 0.334037 \\
\hline$S L C 24 A 4$ & rs12896399 & G & $\mathrm{T}$ & Europeans & Oceanians & $-2.53 \mathrm{E}-04$ & $6.68 \mathrm{E}-04$ & 0.704428 \\
\hline SLC24A4 & rs2402130 & G & A & Europeans & Oceanians & $-9.90 \mathrm{E}-05$ & $6.78 \mathrm{E}-04$ & 0.884527 \\
\hline$O C A 2$ & rs2311843 & $\mathrm{C}$ & $\mathrm{T}$ & Europeans & Oceanians & -0.001052 & $6.68 \mathrm{E}-04$ & 0.115666 \\
\hline$O C A 2$ & rs1800414 & A & G & Europeans & Oceanians & -0.002783 & $7.87 \mathrm{E}-04$ & 4.05E-04 \\
\hline$O C A 2$ & rs1800404 & $\mathrm{C}$ & $\mathrm{T}$ & Europeans & Oceanians & 0.001137 & $6.70 \mathrm{E}-04$ & 0.08982 \\
\hline OCA2 & rs1800401 & $\mathrm{C}$ & $\mathrm{T}$ & Europeans & Oceanians & 8.27E-04 & $9.69 \mathrm{E}-04$ & 0.393278 \\
\hline HERC2 & rs1129038 & G & A & Europeans & Oceanians & 0.003037 & $9.67 \mathrm{E}-04$ & 0.001678 \\
\hline HERC2 & rs 12913832 & A & G & Europeans & Oceanians & 0.003027 & $9.67 \mathrm{E}-04$ & 0.001739 \\
\hline HERC2 & rs916977 & A & G & Europeans & Oceanians & $9.80 \mathrm{E}-04$ & $6.68 \mathrm{E}-04$ & 0.142565 \\
\hline HERC2 & rs1667394 & G & A & Europeans & Oceanians & $9.71 \mathrm{E}-04$ & $6.68 \mathrm{E}-04$ & 0.14624 \\
\hline SLC24A5 & rs1426654 & G & A & Europeans & Oceanians & 0.004289 & 7.89E-04 & 0 \\
\hline MYO5A & rs4776053 & $\mathrm{C}$ & $\mathrm{T}$ & Europeans & Oceanians & $9.60 \mathrm{E}-04$ & 7.76E-04 & 0.215663 \\
\hline
\end{tabular}




\begin{tabular}{|c|c|c|c|c|c|c|c|c|}
\hline$M C 1 R$ & rs 2228479 & $\mathrm{G}$ & A & Europeans & Oceanians & $-1.59 \mathrm{E}-04$ & $6.87 \mathrm{E}-04$ & 0.816976 \\
\hline$M C 1 R$ & rs885479 & $\mathrm{G}$ & A & Europeans & Oceanians & 4.12E-04 & 7.32E-04 & 0.57365 \\
\hline MFSD12 & rs56203814 & $\mathrm{C}$ & $\mathrm{T}$ & Europeans & Oceanians & $-4.43 \mathrm{E}-04$ & $9.95 \mathrm{E}-04$ & 0.655763 \\
\hline MFSD12 & rs 10424065 & $\mathrm{C}$ & $\mathrm{T}$ & Europeans & Oceanians & $-4.43 \mathrm{E}-04$ & $9.95 \mathrm{E}-04$ & 0.655763 \\
\hline MFSD12 & rs6510760 & $\mathrm{G}$ & A & Europeans & Oceanians & -0.001365 & 6.69E-04 & 0.041418 \\
\hline MFSD12 & rs112332856 & $\mathrm{T}$ & $\mathrm{C}$ & Europeans & Oceanians & -0.001282 & $6.75 \mathrm{E}-04$ & 0.057377 \\
\hline$A S I P$ & rs6119471 & $\mathrm{G}$ & $\mathrm{C}$ & Europeans & Oceanians & 0.001543 & 0.001197 & 0.197389 \\
\hline$A S I P$ & rs6058017 & $\mathrm{G}$ & A & Europeans & Oceanians & $1.57 \mathrm{E}-04$ & $6.79 \mathrm{E}-04$ & 0.816854 \\
\hline$P I G U$ & rs2378249 & $\mathrm{A}$ & G & Europeans & Oceanians & $-6.90 \mathrm{E}-05$ & $6.81 \mathrm{E}-04$ & 0.9196 \\
\hline$S L C 45 A 2$ & rs16891982 & $\mathrm{C}$ & G & Europeans & EastAsians & 0.004804 & $7.53 \mathrm{E}-04$ & 0 \\
\hline$S L C 45 A 2$ & rs28777 & $\mathrm{C}$ & A & Europeans & EastAsians & 0.003301 & 7.40E-04 & 8.00E-06 \\
\hline$S L C 45 A 2$ & rs26722 & $\mathrm{C}$ & $\mathrm{T}$ & Europeans & EastAsians & -0.002147 & 7.43E-04 & 0.00388 \\
\hline EXOC2 & rs4959270 & $\mathrm{C}$ & A & Europeans & EastAsians & $2.80 \mathrm{E}-04$ & 7.35E-04 & 0.70332 \\
\hline$T Y R P 1$ & rs1408799 & $\mathrm{T}$ & $\mathrm{C}$ & Europeans & EastAsians & 0.002875 & $7.42 \mathrm{E}-04$ & 1.06E-04 \\
\hline TYRPI & rs683 & A & $\mathrm{C}$ & Europeans & EastAsians & -0.003298 & $7.48 \mathrm{E}-04$ & 1.10E-05 \\
\hline$B N C 2$ & rs10756819 & G & A & Europeans & EastAsians & $2.60 \mathrm{E}-04$ & 7.35E-04 & 0.723261 \\
\hline$B N C 2$ & rs12350739 & G & A & Europeans & EastAsians & 0.003316 & $7.58 \mathrm{E}-04$ & $1.20 \mathrm{E}-05$ \\
\hline$D D B 1$ & rs11230664 & $\mathrm{C}$ & $\mathrm{T}$ & Europeans & EastAsians & 8.84E-04 & 7.60E-04 & 0.244405 \\
\hline$D D B 1$ & rs7120594 & $\mathrm{T}$ & $\mathrm{C}$ & Europeans & EastAsians & 0.001224 & $7.75 \mathrm{E}-04$ & 0.114356 \\
\hline$D D B 1$ & rs7948623 & A & $\mathrm{T}$ & Europeans & EastAsians & $5.27 \mathrm{E}-04$ & $8.46 \mathrm{E}-04$ & 0.533572 \\
\hline$D D B 1$ & rs1377457 & $\mathrm{C}$ & A & Europeans & EastAsians & $-2.40 \mathrm{E}-05$ & $7.80 \mathrm{E}-04$ & 0.97525 \\
\hline TPCN2 & rs35264875 & A & $\mathrm{T}$ & Europeans & EastAsians & 0.002125 & $7.51 \mathrm{E}-04$ & 0.004686 \\
\hline TPCN2 & rs3829241 & G & A & Europeans & EastAsians & $5.75 \mathrm{E}-04$ & 7.35E-04 & 0.43454 \\
\hline$T Y R$ & rs1042602 & $\mathrm{C}$ & A & Europeans & EastAsians & 0.003703 & 8.34E-04 & 9.00E-06 \\
\hline TYR & rs1393350 & G & A & Europeans & EastAsians & 0.003095 & 8.07E-04 & $1.26 \mathrm{E}-04$ \\
\hline$T Y R$ & rs1126809 & $\mathrm{G}$ & A & Europeans & EastAsians & 0.003655 & $8.95 \mathrm{E}-04$ & 4.40E-05 \\
\hline
\end{tabular}




\begin{tabular}{|c|c|c|c|c|c|c|c|c|}
\hline KITLG & rs642742 & A & G & Europeans & EastAsians & $1.58 \mathrm{E}-04$ & $7.36 \mathrm{E}-04$ & 0.829732 \\
\hline KITLG & rs 12821256 & $\mathrm{~T}$ & $\mathrm{C}$ & Europeans & EastAsians & 0.003289 & $8.95 \mathrm{E}-04$ & 2.38E-04 \\
\hline$D C T$ & rs1407995 & $\mathrm{T}$ & $\mathrm{C}$ & Europeans & EastAsians & 0.001625 & $7.36 \mathrm{E}-04$ & 0.027173 \\
\hline$D C T$ & rs2031526 & G & A & Europeans & EastAsians & -0.001627 & $7.36 \mathrm{E}-04$ & 0.026976 \\
\hline$S L C 24 A 4$ & rs12896399 & G & $\mathrm{T}$ & Europeans & EastAsians & $3.12 \mathrm{E}-04$ & 7.35E-04 & 0.67082 \\
\hline$S L C 24 A 4$ & rs2402130 & G & A & Europeans & EastAsians & $-7.69 \mathrm{E}-04$ & 7.37E-04 & 0.296629 \\
\hline$O C A 2$ & rs2311843 & $\mathrm{C}$ & $\mathrm{T}$ & Europeans & EastAsians & -0.00198 & 7.36E-04 & 0.007154 \\
\hline$O C A 2$ & rs1800414 & A & G & Europeans & EastAsians & -0.004515 & 8.94E-04 & $\mathbf{0}$ \\
\hline OCA2 & rs1800404 & $\mathrm{C}$ & $\mathrm{T}$ & Europeans & EastAsians & 0.001211 & 7.35E-04 & 0.099601 \\
\hline$O C A 2$ & rs1800401 & $\mathrm{C}$ & $\mathrm{T}$ & Europeans & EastAsians & 0.001064 & 7.57E-04 & 0.160263 \\
\hline HERC2 & rs1129038 & G & A & Europeans & EastAsians & 0.004539 & 7.92E-04 & 0 \\
\hline HERC2 & rs 12913832 & A & G & Europeans & EastAsians & 0.004684 & 8.07E-04 & $\mathbf{0}$ \\
\hline HERC2 & rs916977 & A & G & Europeans & EastAsians & 0.001788 & 7.36E-04 & 0.015136 \\
\hline HERC2 & rs1667394 & G & A & Europeans & EastAsians & 0.001778 & $7.36 \mathrm{E}-04$ & 0.015681 \\
\hline$S L C 24 A 5$ & rs1426654 & G & A & Europeans & EastAsians & 0.005774 & 7.69E-04 & 0 \\
\hline MYO5A & rs4776053 & $\mathrm{C}$ & $\mathrm{T}$ & Europeans & EastAsians & $-1.45 \mathrm{E}-04$ & 7.36E-04 & 0.844254 \\
\hline$M C 1 R$ & rs2228479 & G & A & Europeans & EastAsians & $-9.51 \mathrm{E}-04$ & 7.37E-04 & 0.196783 \\
\hline$M C 1 R$ & rs885479 & G & A & Europeans & EastAsians & -0.001785 & 7.37E-04 & 0.015392 \\
\hline$M F S D 12$ & rs56203814 & $\mathrm{C}$ & $\mathrm{T}$ & Europeans & EastAsians & 0.001563 & 0.001186 & 0.18755 \\
\hline$M F S D 12$ & rs 10424065 & $\mathrm{C}$ & $\mathrm{T}$ & Europeans & EastAsians & $8.76 \mathrm{E}-04$ & $9.41 \mathrm{E}-04$ & 0.351953 \\
\hline$M F S D 12$ & rs6510760 & G & A & Europeans & EastAsians & $1.37 \mathrm{E}-04$ & $7.40 \mathrm{E}-04$ & 0.85293 \\
\hline MFSD12 & rs112332856 & $\mathrm{T}$ & $\mathrm{C}$ & Europeans & EastAsians & 0.001151 & 7.69E-04 & 0.134437 \\
\hline ASIP & rs6119471 & G & $\mathrm{C}$ & Europeans & EastAsians & $-1.88 \mathrm{E}-04$ & 0.00145 & 0.896809 \\
\hline$A S I P$ & rs6058017 & G & A & Europeans & EastAsians & $4.96 \mathrm{E}-04$ & 7.36E-04 & 0.500451 \\
\hline$P I G U$ & rs2378249 & A & G & Europeans & EastAsians & $-2.14 \mathrm{E}-04$ & $7.36 \mathrm{E}-04$ & 0.770841 \\
\hline SLC45A2 & rs16891982 & $\mathrm{C}$ & G & Europeans & EastAfricans & 0.002845 & $6.31 \mathrm{E}-04$ & $6.00 \mathrm{E}-06$ \\
\hline
\end{tabular}




\begin{tabular}{|c|c|c|c|c|c|c|c|c|}
\hline SLC45A2 & rs28777 & $\mathrm{C}$ & A & Europeans & EastAfricans & 0.001699 & 5.53E-04 & 0.002098 \\
\hline SLC45A2 & rs 26722 & $\mathrm{C}$ & $\mathrm{T}$ & Europeans & EastAfricans & $-4.21 \mathrm{E}-04$ & $5.68 \mathrm{E}-04$ & 0.459218 \\
\hline ЕХOC2 & rs4959270 & $\mathrm{C}$ & A & Europeans & EastAfricans & $9.79 \mathrm{E}-04$ & 5.64E-04 & 0.08264 \\
\hline TYRPI & rs1408799 & $\mathrm{T}$ & $\mathrm{C}$ & Europeans & EastAfricans & 7.12E-04 & $5.50 \mathrm{E}-04$ & 0.195475 \\
\hline TYRPI & rs683 & A & $\mathrm{C}$ & Europeans & EastAfricans & $-8.09 \mathrm{E}-04$ & $5.51 \mathrm{E}-04$ & 0.142307 \\
\hline$B N C 2$ & rs 10756819 & G & A & Europeans & EastAfricans & 0.001721 & $5.97 \mathrm{E}-04$ & 0.003941 \\
\hline$B N C 2$ & rs12350739 & G & A & Europeans & EastAfricans & 0.002164 & 7.70E-04 & 0.004947 \\
\hline$D D B 1$ & rs11230664 & $\mathrm{C}$ & $\mathrm{T}$ & Europeans & EastAfricans & 0.002891 & $5.75 \mathrm{E}-04$ & o \\
\hline$D D B 1$ & rs7120594 & $\mathrm{T}$ & $\mathrm{C}$ & Europeans & EastAfricans & 0.002582 & $5.70 \mathrm{E}-04$ & $6.00 \mathrm{E}-06$ \\
\hline$D D B 1$ & rs7948623 & A & $\mathrm{T}$ & Europeans & EastAfricans & -0.002338 & $5.71 \mathrm{E}-04$ & $4.20 \mathrm{E}-05$ \\
\hline$D D B 1$ & rs1377457 & $\mathrm{C}$ & A & Europeans & EastAfricans & 0.003024 & $5.80 \mathrm{E}-04$ & o \\
\hline TPCN2 & rs 35264875 & A & $\mathrm{T}$ & Europeans & EastAfricans & $8.60 \mathrm{E}-05$ & $5.52 \mathrm{E}-04$ & 0.876402 \\
\hline TPCN2 & rs3829241 & G & A & Europeans & EastAfricans & 0.001304 & 5.97E-04 & 0.028911 \\
\hline$T Y R$ & rs1042602 & $\mathrm{C}$ & A & Europeans & EastAfricans & 0.001831 & 7.70E-04 & 0.017436 \\
\hline$T Y R$ & rs1393350 & G & A & Europeans & EastAfricans & 0.001586 & 7.70E-04 & 0.039444 \\
\hline$T Y R$ & rs1126809 & G & A & Europeans & EastAfricans & 0.001604 & $7.70 \mathrm{E}-04$ & 0.037246 \\
\hline KITLG & rs642742 & A & G & Europeans & EastAfricans & 0.001378 & $5.55 \mathrm{E}-04$ & 0.013057 \\
\hline KITLG & rs 12821256 & $\mathrm{~T}$ & $\mathrm{C}$ & Europeans & EastAfricans & $2.86 \mathrm{E}-04$ & $5.62 \mathrm{E}-04$ & 0.611079 \\
\hline$D C T$ & rs1407995 & $\mathrm{T}$ & $\mathrm{C}$ & Europeans & EastAfricans & $-4.00 \mathrm{E}-05$ & $5.53 \mathrm{E}-04$ & 0.942694 \\
\hline$D C T$ & rs2031526 & G & A & Europeans & EastAfricans & $6.06 \mathrm{E}-04$ & $5.72 \mathrm{E}-04$ & 0.289335 \\
\hline$S L C 24 A 4$ & rs12896399 & G & $\mathrm{T}$ & Europeans & EastAfricans & $9.89 \mathrm{E}-04$ & $5.64 \mathrm{E}-04$ & 0.079557 \\
\hline$S L C 24 A 4$ & rs2402130 & G & A & Europeans & EastAfricans & $5.86 \mathrm{E}-04$ & $5.49 \mathrm{E}-04$ & 0.285706 \\
\hline$O C A 2$ & rs2311843 & $\mathrm{C}$ & $\mathrm{T}$ & Europeans & EastAfricans & $9.39 \mathrm{E}-04$ & $6.29 \mathrm{E}-04$ & 0.135776 \\
\hline$O C A 2$ & rs1800414 & A & G & Europeans & EastAfricans & $-5.29 \mathrm{E}-04$ & 8.31E-04 & 0.524534 \\
\hline$O C A 2$ & rs1800404 & $\mathrm{C}$ & $\mathrm{T}$ & Europeans & EastAfricans & 0.001814 & $5.75 \mathrm{E}-04$ & 0.001596 \\
\hline OCA2 & rs1800401 & $\mathrm{C}$ & $\mathrm{T}$ & Europeans & EastAfricans & $1.30 \mathrm{E}-05$ & $5.77 \mathrm{E}-04$ & 0.982 \\
\hline
\end{tabular}




\begin{tabular}{|c|c|c|c|c|c|c|c|c|}
\hline HERC2 & rs1129038 & $\mathrm{G}$ & A & Europeans & EastAfricans & 0.002572 & 7.70E-04 & 8.41E-04 \\
\hline HERC2 & rs12913832 & A & $\mathrm{G}$ & Europeans & EastAfricans & 0.002564 & 7.70E-04 & 8.72E-04 \\
\hline HERC2 & rs916977 & A & $\mathrm{G}$ & Europeans & EastAfricans & 0.002182 & 5.97E-04 & $2.60 \mathrm{E}-04$ \\
\hline HERC2 & rs1667394 & G & A & Europeans & EastAfricans & 0.002175 & $5.97 \mathrm{E}-04$ & 2.72E-04 \\
\hline$S L C 24 A 5$ & rs1426654 & G & A & Europeans & EastAfricans & 0.003205 & $5.94 \mathrm{E}-04$ & $\mathbf{0}$ \\
\hline MYO5A & rs4776053 & $\mathrm{C}$ & $\mathrm{T}$ & Europeans & EastAfricans & 3.64E-04 & $5.65 \mathrm{E}-04$ & 0.518997 \\
\hline$M C 1 R$ & rs2228479 & G & $\mathrm{A}$ & Europeans & EastAfricans & 0.001173 & 7.71E-04 & 0.128136 \\
\hline$M C 1 R$ & rs885479 & G & $\mathrm{A}$ & Europeans & EastAfricans & 0.001183 & 7.71E-04 & 0.124649 \\
\hline MFSD12 & rs56203814 & $\mathrm{C}$ & $\mathrm{T}$ & Europeans & EastAfricans & -0.001548 & 5.81E-04 & 0.007776 \\
\hline$M F S D 12$ & rs10424065 & $\mathrm{C}$ & $\mathrm{T}$ & Europeans & EastAfricans & -0.002352 & $5.78 \mathrm{E}-04$ & 4.60E-05 \\
\hline$M F S D 12$ & rs6510760 & G & A & Europeans & EastAfricans & -0.002269 & 5.76E-04 & 8.10E-05 \\
\hline$M F S D 12$ & rs112332856 & $\mathrm{T}$ & $\mathrm{C}$ & Europeans & EastAfricans & -0.00259 & 5.77E-04 & $7.00 \mathrm{E}-06$ \\
\hline$A S I P$ & rs6119471 & G & $\mathrm{C}$ & Europeans & EastAfricans & 0.002737 & 7.73E-04 & 3.98E-04 \\
\hline$A S I P$ & rs6058017 & G & A & Europeans & EastAfricans & 0.001219 & $5.51 \mathrm{E}-04$ & 0.026928 \\
\hline$P I G U$ & rs2378249 & A & G & Europeans & EastAfricans & $3.14 \mathrm{E}-04$ & $5.65 \mathrm{E}-04$ & 0.578311 \\
\hline SLC45A2 & rs16891982 & $\mathrm{C}$ & G & Europeans & WestAfricans & 0.00263 & 4.79E-04 & $\mathbf{0}$ \\
\hline SLC45A2 & rs28777 & $\mathrm{C}$ & A & Europeans & WestAfricans & 0.001508 & $4.52 \mathrm{E}-04$ & 8.40E-04 \\
\hline SLC45A2 & rs26722 & $\mathrm{C}$ & $\mathrm{T}$ & Europeans & WestAfricans & $-2.48 \mathrm{E}-04$ & $4.55 \mathrm{E}-04$ & 0.585986 \\
\hline EXOC2 & rs4959270 & $\mathrm{C}$ & A & Europeans & WestAfricans & $3.28 \mathrm{E}-04$ & $4.50 \mathrm{E}-04$ & 0.465309 \\
\hline TYRPI & rs1408799 & $\mathrm{T}$ & $\mathrm{C}$ & Europeans & WestAfricans & $6.83 \mathrm{E}-04$ & $4.50 \mathrm{E}-04$ & 0.128978 \\
\hline TYRPI & rs683 & A & $\mathrm{C}$ & Europeans & WestAfricans & $-8.97 \mathrm{E}-04$ & $4.50 \mathrm{E}-04$ & 0.046465 \\
\hline$B N C 2$ & rs10756819 & G & A & Europeans & WestAfricans & $9.96 \mathrm{E}-04$ & $4.51 \mathrm{E}-04$ & 0.027057 \\
\hline$B N C 2$ & rs12350739 & G & A & Europeans & WestAfricans & 0.00186 & $4.88 \mathrm{E}-04$ & 1.39E-04 \\
\hline$D D B 1$ & rs11230664 & $\mathrm{C}$ & $\mathrm{T}$ & Europeans & WestAfricans & 0.001682 & $4.58 \mathrm{E}-04$ & 2.38E-04 \\
\hline$D D B 1$ & rs7120594 & $\mathrm{T}$ & $\mathrm{C}$ & Europeans & WestAfricans & 0.001719 & $4.64 \mathrm{E}-04$ & 2.09E-04 \\
\hline$D D B 1$ & rs7948623 & A & $\mathrm{T}$ & Europeans & WestAfricans & -0.001286 & 4.66E-04 & 0.005809 \\
\hline
\end{tabular}




\begin{tabular}{|c|c|c|c|c|c|c|c|c|}
\hline$D D B 1$ & rs1377457 & $\mathrm{C}$ & A & Europeans & WestAfricans & 0.001757 & $4.59 \mathrm{E}-04$ & 1.31E-04 \\
\hline TPCN2 & rs35264875 & A & $\mathrm{T}$ & Europeans & WestAfricans & 0.001083 & 4.64E-04 & 0.019467 \\
\hline TPCN2 & rs3829241 & $\mathrm{G}$ & A & Europeans & WestAfricans & $9.58 \mathrm{E}-04$ & $4.53 \mathrm{E}-04$ & 0.034415 \\
\hline$T Y R$ & rs1042602 & $\mathrm{C}$ & A & Europeans & WestAfricans & 0.001495 & 4.77E-04 & 0.001739 \\
\hline$T Y R$ & rs1393350 & G & A & Europeans & WestAfricans & 0.001893 & $6.21 \mathrm{E}-04$ & 0.002296 \\
\hline$T Y R$ & rs1126809 & G & A & Europeans & WestAfricans & 0.001317 & $4.78 \mathrm{E}-04$ & 0.005828 \\
\hline KITLG & rs642742 & A & G & Europeans & WestAfricans & 0.001239 & $4.51 \mathrm{E}-04$ & 0.005976 \\
\hline KITLG & rs 12821256 & $\mathrm{~T}$ & $\mathrm{C}$ & Europeans & WestAfricans & 0.00173 & $6.21 \mathrm{E}-04$ & 0.005338 \\
\hline$D C T$ & rs1407995 & $\mathrm{T}$ & $\mathrm{C}$ & Europeans & WestAfricans & $6.70 \mathrm{E}-05$ & $4.50 \mathrm{E}-04$ & 0.881067 \\
\hline$D C T$ & rs2031526 & G & A & Europeans & WestAfricans & $3.96 \mathrm{E}-04$ & $4.51 \mathrm{E}-04$ & 0.380466 \\
\hline$S L C 24 A 4$ & rs12896399 & G & $\mathrm{T}$ & Europeans & WestAfricans & 0.001753 & $4.88 \mathrm{E}-04$ & 3.32E-04 \\
\hline$S L C 24 A 4$ & rs 2402130 & G & A & Europeans & WestAfricans & $5.91 \mathrm{E}-04$ & $4.50 \mathrm{E}-04$ & 0.188372 \\
\hline$O C A 2$ & rs2311843 & $\mathrm{C}$ & $\mathrm{T}$ & Europeans & WestAfricans & $5.25 \mathrm{E}-04$ & 4.54E-04 & 0.246673 \\
\hline$O C A 2$ & rs1800414 & A & G & Europeans & WestAfricans & $2.26 \mathrm{E}-04$ & $6.68 \mathrm{E}-04$ & 0.734638 \\
\hline OCA2 & rs1800404 & $\mathrm{C}$ & $\mathrm{T}$ & Europeans & WestAfricans & 0.001079 & $4.50 \mathrm{E}-04$ & 0.016588 \\
\hline$O C A 2$ & rs1800401 & $\mathrm{C}$ & $\mathrm{T}$ & Europeans & WestAfricans & $-4.49 \mathrm{E}-04$ & $4.51 \mathrm{E}-04$ & 0.320382 \\
\hline HERC2 & rs1129038 & G & A & Europeans & WestAfricans & 0.00197 & 4.69E-04 & $2.70 \mathrm{E}-05$ \\
\hline HERC2 & rs 12913832 & A & G & Europeans & WestAfricans & 0.001964 & 4.69E-04 & $2.80 \mathrm{E}-05$ \\
\hline HERC2 & rs916977 & A & G & Europeans & WestAfricans & 0.001317 & $4.51 \mathrm{E}-04$ & 0.003482 \\
\hline HERC2 & rs1667394 & G & A & Europeans & WestAfricans & 0.001354 & $4.51 \mathrm{E}-04$ & 0.002681 \\
\hline$S L C 24 A 5$ & rs1426654 & G & A & Europeans & WestAfricans & 0.002367 & 4.60E-04 & 0 \\
\hline MYO5A & rs4776053 & $\mathrm{C}$ & $\mathrm{T}$ & Europeans & WestAfricans & $1.97 \mathrm{E}-04$ & $4.51 \mathrm{E}-04$ & 0.661346 \\
\hline$M C 1 R$ & rs2228479 & G & A & Europeans & WestAfricans & 0.001567 & $6.21 \mathrm{E}-04$ & 0.011649 \\
\hline$M C 1 R$ & rs885479 & G & A & Europeans & WestAfricans & 0.001576 & $6.21 \mathrm{E}-04$ & 0.011201 \\
\hline MFSD 12 & rs56203814 & $\mathrm{C}$ & $\mathrm{T}$ & Europeans & WestAfricans & -0.001347 & 4.72E-04 & 0.004295 \\
\hline MFSD12 & rs 10424065 & $\mathrm{C}$ & $\mathrm{T}$ & Europeans & WestAfricans & -0.001503 & 4.71E-04 & 0.001434 \\
\hline
\end{tabular}




\begin{tabular}{|c|c|c|c|c|c|c|c|c|}
\hline MFSD12 & rs6510760 & G & A & Europeans & WestAfricans & -0.001407 & $4.51 \mathrm{E}-04$ & 0.001801 \\
\hline MFSD12 & rs112332856 & $\mathrm{T}$ & $\mathrm{C}$ & Europeans & WestAfricans & -0.001501 & $4.52 \mathrm{E}-04$ & 8.93E-04 \\
\hline$A S I P$ & rs6119471 & G & $\mathrm{C}$ & Europeans & WestAfricans & 0.002735 & $6.21 \mathrm{E}-04$ & 1.10E-05 \\
\hline$A S I P$ & rs6058017 & G & A & Europeans & WestAfricans & 0.001095 & $4.50 \mathrm{E}-04$ & 0.015015 \\
\hline$P I G U$ & rs2378249 & A & G & Europeans & WestAfricans & $-8.40 \mathrm{E}-05$ & $4.50 \mathrm{E}-04$ & 0.852618 \\
\hline$S L C 45 A 2$ & rs16891982 & $\mathrm{C}$ & G & NorthAsians & Oceanians & 2.09E-04 & $6.90 \mathrm{E}-04$ & 0.761863 \\
\hline$S L C 45 A 2$ & rs28777 & $\mathrm{C}$ & A & NorthAsians & Oceanians & $-7.11 \mathrm{E}-04$ & $6.59 \mathrm{E}-04$ & 0.280548 \\
\hline SLC45A2 & rs 26722 & $\mathrm{C}$ & $\mathrm{T}$ & NorthAsians & Oceanians & $7.70 \mathrm{E}-05$ & $6.62 \mathrm{E}-04$ & 0.907271 \\
\hline ЕХOC2 & rs4959270 & $\mathrm{C}$ & A & NorthAsians & Oceanians & -0.001411 & $6.72 \mathrm{E}-04$ & 0.03568 \\
\hline TYRPI & rs1408799 & $\mathrm{T}$ & $\mathrm{C}$ & NorthAsians & Oceanians & $-8.50 \mathrm{E}-05$ & 7.99E-04 & 0.915284 \\
\hline TYRPI & rs683 & A & $\mathrm{C}$ & NorthAsians & Oceanians & $-3.28 \mathrm{E}-04$ & 7.79E-04 & 0.67392 \\
\hline$B N C 2$ & rs 10756819 & G & A & NorthAsians & Oceanians & $1.32 \mathrm{E}-04$ & $6.56 \mathrm{E}-04$ & 0.840146 \\
\hline$B N C 2$ & rs12350739 & G & A & NorthAsians & Oceanians & $5.27 \mathrm{E}-04$ & $9.83 \mathrm{E}-04$ & 0.591614 \\
\hline$D D B 1$ & rs 11230664 & $\mathrm{C}$ & $\mathrm{T}$ & NorthAsians & Oceanians & 0.002999 & $9.63 \mathrm{E}-04$ & 0.001845 \\
\hline$D D B 1$ & rs7120594 & $\mathrm{T}$ & $\mathrm{C}$ & NorthAsians & Oceanians & 0.002999 & $9.63 \mathrm{E}-04$ & 0.001845 \\
\hline$D D B 1$ & rs7948623 & A & $\mathrm{T}$ & NorthAsians & Oceanians & -0.002904 & $9.63 \mathrm{E}-04$ & 0.00257 \\
\hline$D D B 1$ & rs1377457 & $\mathrm{C}$ & A & NorthAsians & Oceanians & 0.002999 & $9.63 \mathrm{E}-04$ & 0.001845 \\
\hline TPCN2 & rs 35264875 & A & $\mathrm{T}$ & NorthAsians & Oceanians & -0.001741 & $6.91 \mathrm{E}-04$ & 0.011742 \\
\hline TPCN2 & rs3829241 & G & A & NorthAsians & Oceanians & 0.001063 & 7.01E-04 & 0.12938 \\
\hline$T Y R$ & rs1042602 & $\mathrm{C}$ & A & NorthAsians & Oceanians & 4.72E-04 & $9.85 \mathrm{E}-04$ & 0.631774 \\
\hline$T Y R$ & rs1393350 & G & A & NorthAsians & Oceanians & $-8.40 \mathrm{E}-05$ & 0.00104 & 0.935849 \\
\hline$T Y R$ & rs1126809 & G & A & NorthAsians & Oceanians & $-8.40 \mathrm{E}-05$ & 0.00104 & 0.935849 \\
\hline KITLG & rs642742 & A & G & NorthAsians & Oceanians & $2.60 \mathrm{E}-04$ & $6.66 \mathrm{E}-04$ & 0.696333 \\
\hline KITLG & rs 12821256 & $\mathrm{~T}$ & $\mathrm{C}$ & NorthAsians & Oceanians & $-6.35 \mathrm{E}-04$ & 0.00119 & 0.593386 \\
\hline$D C T$ & rs1407995 & $\mathrm{T}$ & $\mathrm{C}$ & NorthAsians & Oceanians & $-5.75 \mathrm{E}-04$ & $6.57 \mathrm{E}-04$ & 0.381764 \\
\hline$D C T$ & rs2031526 & G & A & NorthAsians & Oceanians & $5.75 \mathrm{E}-04$ & $6.57 \mathrm{E}-04$ & 0.381764 \\
\hline
\end{tabular}




\begin{tabular}{|c|c|c|c|c|c|c|c|c|}
\hline SLC24A4 & rs12896399 & G & $\mathrm{T}$ & NorthAsians & Oceanians & $-5.34 \mathrm{E}-04$ & $6.57 \mathrm{E}-04$ & 0.416225 \\
\hline SLC $24 A 4$ & rs2402130 & G & A & NorthAsians & Oceanians & $8.10 \mathrm{E}-05$ & $6.70 \mathrm{E}-04$ & 0.903342 \\
\hline$O C A 2$ & rs2311843 & $\mathrm{C}$ & $\mathrm{T}$ & NorthAsians & Oceanians & $5.03 \mathrm{E}-04$ & $6.58 \mathrm{E}-04$ & 0.444072 \\
\hline$O C A 2$ & rs1800414 & A & G & NorthAsians & Oceanians & $-5.92 \mathrm{E}-04$ & $6.70 \mathrm{E}-04$ & 0.376725 \\
\hline$O C A 2$ & rs1800404 & $\mathrm{C}$ & $\mathrm{T}$ & NorthAsians & Oceanians & 0.001338 & $6.62 \mathrm{E}-04$ & 0.04329 \\
\hline$O C A 2$ & rs1800401 & $\mathrm{C}$ & $\mathrm{T}$ & NorthAsians & Oceanians & $6.21 \mathrm{E}-04$ & $9.78 \mathrm{E}-04$ & 0.525882 \\
\hline HERC2 & rs1129038 & G & A & NorthAsians & Oceanians & $1.74 \mathrm{E}-04$ & 0.001008 & 0.862992 \\
\hline HERC2 & rs12913832 & A & G & NorthAsians & Oceanians & $1.74 \mathrm{E}-04$ & 0.001008 & 0.862992 \\
\hline HERC2 & rs916977 & A & G & NorthAsians & Oceanians & $-3.76 \mathrm{E}-04$ & $6.57 \mathrm{E}-04$ & 0.567236 \\
\hline HERC2 & rs1667394 & G & A & NorthAsians & Oceanians & $-3.76 \mathrm{E}-04$ & $6.57 \mathrm{E}-04$ & 0.567236 \\
\hline$S L C 24 A 5$ & rs1426654 & G & A & NorthAsians & Oceanians & $9.81 \mathrm{E}-04$ & $7.68 \mathrm{E}-04$ & 0.201703 \\
\hline MYO5A & rs4776053 & $\mathrm{C}$ & $\mathrm{T}$ & NorthAsians & Oceanians & 0.001571 & 7.65E-04 & 0.04014 \\
\hline$M C 1 R$ & rs2228479 & G & A & NorthAsians & Oceanians & $6.21 \mathrm{E}-04$ & $6.75 \mathrm{E}-04$ & 0.357846 \\
\hline$M C 1 R$ & rs885479 & G & A & NorthAsians & Oceanians & 0.001875 & $7.21 \mathrm{E}-04$ & 0.009264 \\
\hline MFSD 12 & rs56203814 & $\mathrm{C}$ & $\mathrm{T}$ & NorthAsians & Oceanians & $-6.35 \mathrm{E}-04$ & 0.00119 & 0.593386 \\
\hline$M F S D 12$ & rs 10424065 & $\mathrm{C}$ & $\mathrm{T}$ & NorthAsians & Oceanians & $-6.35 \mathrm{E}-04$ & 0.00119 & 0.593386 \\
\hline$M F S D 12$ & rs6510760 & G & A & NorthAsians & Oceanians & -0.001476 & $6.69 \mathrm{E}-04$ & 0.027402 \\
\hline$M F S D 12$ & rs112332856 & $\mathrm{T}$ & $\mathrm{C}$ & NorthAsians & Oceanians & -0.002041 & 7.73E-04 & 0.008293 \\
\hline$A S I P$ & rs6119471 & G & $\mathrm{C}$ & NorthAsians & Oceanians & $6.35 \mathrm{E}-04$ & 0.00119 & 0.593386 \\
\hline$A S I P$ & rs6058017 & G & A & NorthAsians & Oceanians & 0.001111 & 7.05E-04 & 0.115076 \\
\hline$P I G U$ & rs2378249 & A & G & NorthAsians & Oceanians & $3.90 \mathrm{E}-04$ & $6.70 \mathrm{E}-04$ & 0.560041 \\
\hline SLC45A2 & rs16891982 & $\mathrm{C}$ & G & NorthAsians & EastAsians & 0.001997 & $5.71 \mathrm{E}-04$ & 4.71E-04 \\
\hline SLC45A2 & rs28777 & $\mathrm{C}$ & A & NorthAsians & EastAsians & $2.38 \mathrm{E}-04$ & $5.38 \mathrm{E}-04$ & 0.657895 \\
\hline$S L C 45 A 2$ & rs26722 & $\mathrm{C}$ & $\mathrm{T}$ & NorthAsians & EastAsians & $-4.67 \mathrm{E}-04$ & 5.31E-04 & 0.378937 \\
\hline EXOC2 & rs4959270 & $\mathrm{C}$ & A & NorthAsians & EastAsians & $-1.62 \mathrm{E}-04$ & 5.30E-04 & 0.759375 \\
\hline TYRPI & rs1408799 & $\mathrm{T}$ & $\mathrm{C}$ & NorthAsians & EastAsians & $6.00 \mathrm{E}-06$ & $6.46 \mathrm{E}-04$ & 0.992184 \\
\hline
\end{tabular}




\begin{tabular}{|c|c|c|c|c|c|c|c|c|}
\hline TYRPI & rs683 & A & $\mathrm{C}$ & NorthAsians & EastAsians & -0.001162 & $6.01 \mathrm{E}-04$ & 0.053093 \\
\hline$B N C 2$ & rs10756819 & $\mathrm{G}$ & A & NorthAsians & EastAsians & $3.40 \mathrm{E}-05$ & $5.28 \mathrm{E}-04$ & 0.948733 \\
\hline$B N C 2$ & rs 12350739 & G & A & NorthAsians & EastAsians & 0.001035 & $6.65 \mathrm{E}-04$ & 0.119833 \\
\hline$D D B 1$ & rs11230664 & $\mathrm{C}$ & $\mathrm{T}$ & NorthAsians & EastAsians & 0.002143 & 0.001209 & 0.076471 \\
\hline$D D B 1$ & rs7120594 & $\mathrm{T}$ & $\mathrm{C}$ & NorthAsians & EastAsians & 0.002143 & 0.001209 & 0.076471 \\
\hline$D D B 1$ & rs7948623 & A & $\mathrm{T}$ & NorthAsians & EastAsians & $1.30 \mathrm{E}-04$ & 0.001274 & 0.918425 \\
\hline$D D B 1$ & rs1377457 & $\mathrm{C}$ & A & NorthAsians & EastAsians & $8.83 \mathrm{E}-04$ & 0.001224 & 0.470813 \\
\hline TPCN2 & rs 35264875 & A & $\mathrm{T}$ & NorthAsians & EastAsians & 7.44E-04 & $6.52 \mathrm{E}-04$ & 0.253889 \\
\hline TPCN2 & rs3829241 & G & A & NorthAsians & EastAsians & 4.87E-04 & $5.30 \mathrm{E}-04$ & 0.358337 \\
\hline$T Y R$ & rs1042602 & $\mathrm{C}$ & A & NorthAsians & EastAsians & 0.002093 & 7.99E-04 & 0.008792 \\
\hline$T Y R$ & rs1393350 & G & A & NorthAsians & EastAsians & 9.79E-04 & $9.13 \mathrm{E}-04$ & 0.28368 \\
\hline$T Y R$ & rs1126809 & G & A & NorthAsians & EastAsians & 0.001632 & 0.001029 & 0.112903 \\
\hline KITLG & rs642742 & A & G & NorthAsians & EastAsians & $4.33 \mathrm{E}-04$ & $5.40 \mathrm{E}-04$ & 0.422821 \\
\hline KITLG & rs 12821256 & $\mathrm{~T}$ & $\mathrm{C}$ & NorthAsians & EastAsians & 7.83E-04 & 0.001359 & 0.564616 \\
\hline$D C T$ & rs1407995 & $\mathrm{T}$ & $\mathrm{C}$ & NorthAsians & EastAsians & $1.19 \mathrm{E}-04$ & $5.31 \mathrm{E}-04$ & 0.822512 \\
\hline$D C T$ & rs2031526 & G & A & NorthAsians & EastAsians & $-1.25 \mathrm{E}-04$ & $5.31 \mathrm{E}-04$ & 0.813192 \\
\hline$S L C 24 A 4$ & rs12896399 & G & $\mathrm{T}$ & NorthAsians & EastAsians & $-4.70 \mathrm{E}-05$ & $5.30 \mathrm{E}-04$ & 0.928955 \\
\hline SLC24A4 & rs2402130 & G & A & NorthAsians & EastAsians & $-6.70 \mathrm{E}-04$ & $5.43 \mathrm{E}-04$ & 0.217046 \\
\hline OCA2 & rs2311843 & $\mathrm{C}$ & $\mathrm{T}$ & NorthAsians & EastAsians & $-4.50 \mathrm{E}-05$ & $5.33 \mathrm{E}-04$ & 0.933321 \\
\hline$O C A 2$ & rs1800414 & A & G & NorthAsians & EastAsians & -0.002186 & $5.52 \mathrm{E}-04$ & $7.40 \mathrm{E}-05$ \\
\hline$O C A 2$ & rs1800404 & $\mathrm{C}$ & $\mathrm{T}$ & NorthAsians & EastAsians & 0.0018 & $5.40 \mathrm{E}-04$ & 8.52E-04 \\
\hline$O C A 2$ & rs1800401 & $\mathrm{C}$ & $\mathrm{T}$ & NorthAsians & EastAsians & $9.92 \mathrm{E}-04$ & $6.41 \mathrm{E}-04$ & 0.122014 \\
\hline HERC2 & rs1129038 & G & A & NorthAsians & EastAsians & 0.001182 & 7.99E-04 & 0.139204 \\
\hline HERC2 & rs12913832 & A & G & NorthAsians & EastAsians & 0.001375 & $8.22 \mathrm{E}-04$ & 0.094386 \\
\hline HERC2 & rs916977 & A & G & NorthAsians & EastAsians & $1.14 \mathrm{E}-04$ & $5.30 \mathrm{E}-04$ & 0.829383 \\
\hline HERC2 & rs1667394 & G & A & NorthAsians & EastAsians & $1.16 \mathrm{E}-04$ & $5.30 \mathrm{E}-04$ & 0.826312 \\
\hline
\end{tabular}




\begin{tabular}{|c|c|c|c|c|c|c|c|c|}
\hline$S L C 24 A 5$ & rs1426654 & G & A & NorthAsians & EastAsians & 0.002017 & $5.61 \mathrm{E}-04$ & 3.21E-04 \\
\hline MYO5A & rs4776053 & $\mathrm{C}$ & $\mathrm{T}$ & NorthAsians & EastAsians & 7.61E-04 & $5.30 \mathrm{E}-04$ & 0.1509 \\
\hline$M C 1 R$ & rs2228479 & G & A & NorthAsians & EastAsians & $2.90 \mathrm{E}-05$ & $5.30 \mathrm{E}-04$ & 0.956249 \\
\hline$M C 1 R$ & rs885479 & G & A & NorthAsians & EastAsians & $5.40 \mathrm{E}-05$ & 5.29E-04 & 0.918692 \\
\hline MFSD12 & rs56203814 & $\mathrm{C}$ & $\mathrm{T}$ & NorthAsians & EastAsians & 0.001629 & 0.001624 & 0.315933 \\
\hline MFSD 12 & rs 10424065 & $\mathrm{C}$ & $\mathrm{T}$ & NorthAsians & EastAsians & $7.83 \mathrm{E}-04$ & 0.001359 & 0.564616 \\
\hline MFSD12 & rs6510760 & G & A & NorthAsians & EastAsians & $-3.00 \mathrm{E}-06$ & $5.71 \mathrm{E}-04$ & 0.996409 \\
\hline MFSD12 & rs112332856 & $\mathrm{T}$ & $\mathrm{C}$ & NorthAsians & EastAsians & $2.50 \mathrm{E}-04$ & $8.55 \mathrm{E}-04$ & 0.769913 \\
\hline$A S I P$ & rs6119471 & G & $\mathrm{C}$ & NorthAsians & EastAsians & -0.001629 & 0.001624 & 0.315933 \\
\hline$A S I P$ & rs6058017 & G & A & NorthAsians & EastAsians & 0.002077 & $6.35 \mathrm{E}-04$ & 0.001071 \\
\hline$P I G U$ & rs2378249 & A & G & NorthAsians & EastAsians & $4.42 \mathrm{E}-04$ & 5.32E-04 & 0.405868 \\
\hline SLC45A2 & rs16891982 & $\mathrm{C}$ & G & NorthAsians & EastAfricans & 8.87E-04 & 7.11E-04 & 0.21234 \\
\hline$S L C 45 A 2$ & rs28777 & $\mathrm{C}$ & A & NorthAsians & EastAfricans & $-2.13 \mathrm{E}-04$ & $6.41 \mathrm{E}-04$ & 0.740327 \\
\hline SLC45A2 & rs26722 & $\mathrm{C}$ & $\mathrm{T}$ & NorthAsians & EastAfricans & $6.67 \mathrm{E}-04$ & $6.52 \mathrm{E}-04$ & 0.306577 \\
\hline EXOC2 & rs4959270 & $\mathrm{C}$ & A & NorthAsians & EastAfricans & $7.26 \mathrm{E}-04$ & $6.52 \mathrm{E}-04$ & 0.26576 \\
\hline TYRPI & rs1408799 & $\mathrm{T}$ & $\mathrm{C}$ & NorthAsians & EastAfricans & -0.001054 & $6.63 \mathrm{E}-04$ & 0.11218 \\
\hline$T Y R P 1$ & rs683 & A & $\mathrm{C}$ & NorthAsians & EastAfricans & $6.40 \mathrm{E}-04$ & $6.50 \mathrm{E}-04$ & 0.325313 \\
\hline$B N C 2$ & rs 10756819 & G & A & NorthAsians & EastAfricans & 0.001578 & $6.80 \mathrm{E}-04$ & 0.020383 \\
\hline$B N C 2$ & rs 12350739 & G & A & NorthAsians & EastAfricans & $6.41 \mathrm{E}-04$ & 8.53E-04 & 0.45233 \\
\hline$D D B 1$ & rs11230664 & $\mathrm{C}$ & $\mathrm{T}$ & NorthAsians & EastAfricans & 0.003418 & $8.48 \mathrm{E}-04$ & 5.50E-05 \\
\hline$D D B 1$ & rs7120594 & $\mathrm{T}$ & $\mathrm{C}$ & NorthAsians & EastAfricans & 0.0029 & 8.39E-04 & $5.48 E-04$ \\
\hline$D D B 1$ & rs7948623 & A & $\mathrm{T}$ & NorthAsians & EastAfricans & -0.002597 & 8.38E-04 & 0.001932 \\
\hline$D D B 1$ & rs1377457 & $\mathrm{C}$ & A & NorthAsians & EastAfricans & 0.00348 & $8.50 \mathrm{E}-04$ & 4.20E-05 \\
\hline TPCN2 & rs 35264875 & A & $\mathrm{T}$ & NorthAsians & EastAfricans & $-8.49 \mathrm{E}-04$ & $6.62 \mathrm{E}-04$ & 0.199751 \\
\hline TPCN2 & rs3829241 & G & A & NorthAsians & EastAfricans & 0.001194 & $6.80 \mathrm{E}-04$ & 0.079327 \\
\hline$T Y R$ & rs1042602 & $\mathrm{C}$ & A & NorthAsians & EastAfricans & $5.99 \mathrm{E}-04$ & $8.55 \mathrm{E}-04$ & 0.48367 \\
\hline
\end{tabular}




\begin{tabular}{|c|c|c|c|c|c|c|c|c|}
\hline$T Y R$ & rs1393350 & G & A & NorthAsians & EastAfricans & $1.71 \mathrm{E}-04$ & 8.92E-04 & 0.848096 \\
\hline$T Y R$ & rs1126809 & G & A & NorthAsians & EastAfricans & $1.71 \mathrm{E}-04$ & 8.92E-04 & 0.848096 \\
\hline KITLG & rs642742 & A & G & NorthAsians & EastAfricans & 0.001497 & $6.46 \mathrm{E}-04$ & 0.020482 \\
\hline KITLG & rs 12821256 & $\mathrm{~T}$ & $\mathrm{C}$ & NorthAsians & EastAfricans & -0.001347 & 8.46E-04 & 0.111491 \\
\hline$D C T$ & rs1407995 & $\mathrm{T}$ & $\mathrm{C}$ & NorthAsians & EastAfricans & $-9.80 \mathrm{E}-04$ & $6.42 \mathrm{E}-04$ & 0.126771 \\
\hline$D C T$ & rs 2031526 & G & A & NorthAsians & EastAfricans & 0.001545 & $6.59 \mathrm{E}-04$ & 0.019011 \\
\hline$S L C 24 A 4$ & rs12896399 & G & $\mathrm{T}$ & NorthAsians & EastAfricans & $7.73 \mathrm{E}-04$ & $6.52 \mathrm{E}-04$ & 0.235596 \\
\hline SLC24A4 & rs2402130 & G & A & NorthAsians & EastAfricans & $7.24 \mathrm{E}-04$ & $6.40 \mathrm{E}-04$ & 0.258123 \\
\hline OCA2 & rs2311843 & $\mathrm{C}$ & $\mathrm{T}$ & NorthAsians & EastAfricans & 0.002135 & 7.09E-04 & 0.002614 \\
\hline$O C A 2$ & rs1800414 & A & G & NorthAsians & EastAfricans & 0.001157 & $8.40 \mathrm{E}-04$ & 0.168583 \\
\hline OCA2 & rs1800404 & $\mathrm{C}$ & $\mathrm{T}$ & NorthAsians & EastAfricans & 0.001969 & $6.63 \mathrm{E}-04$ & 0.002979 \\
\hline$O C A 2$ & rs1800401 & $\mathrm{C}$ & $\mathrm{T}$ & NorthAsians & EastAfricans & $-1.46 \mathrm{E}-04$ & $6.78 \mathrm{E}-04$ & 0.829763 \\
\hline HERC2 & rs1129038 & G & A & NorthAsians & EastAfricans & 3.69E-04 & 8.70E-04 & 0.671346 \\
\hline HERC2 & rs 12913832 & A & G & NorthAsians & EastAfricans & $3.69 \mathrm{E}-04$ & 8.70E-04 & 0.671346 \\
\hline HERC2 & rs916977 & A & G & NorthAsians & EastAfricans & 0.001139 & $6.81 \mathrm{E}-04$ & 0.094325 \\
\hline HERC2 & rs1667394 & G & A & NorthAsians & EastAfricans & 0.001139 & $6.81 \mathrm{E}-04$ & 0.094325 \\
\hline SLC24A5 & rs1426654 & G & A & NorthAsians & EastAfricans & $6.60 \mathrm{E}-04$ & $6.70 \mathrm{E}-04$ & 0.324444 \\
\hline MYO5A & rs4776053 & $\mathrm{C}$ & $\mathrm{T}$ & NorthAsians & EastAfricans & 8.34E-04 & $6.52 \mathrm{E}-04$ & 0.200935 \\
\hline$M C 1 R$ & rs2228479 & G & A & NorthAsians & EastAfricans & 0.001772 & 8.37E-04 & 0.034127 \\
\hline$M C 1 R$ & rs885479 & G & A & NorthAsians & EastAfricans & 0.002309 & 8.36E-04 & 0.005774 \\
\hline MFSD12 & rs56203814 & $\mathrm{C}$ & $\mathrm{T}$ & NorthAsians & EastAfricans & -0.001695 & $8.40 \mathrm{E}-04$ & 0.043614 \\
\hline MFSD12 & rs 10424065 & $\mathrm{C}$ & $\mathrm{T}$ & NorthAsians & EastAfricans & -0.0025 & 8.37E-04 & 0.002835 \\
\hline MFSD12 & rs6510760 & G & A & NorthAsians & EastAfricans & -0.002355 & $6.68 \mathrm{E}-04$ & 4.27E-04 \\
\hline MFSD12 & rs112332856 & $\mathrm{T}$ & $\mathrm{C}$ & NorthAsians & EastAfricans & -0.003174 & 7.30E-04 & 1.40E-05 \\
\hline ASIP & rs6119471 & G & $\mathrm{C}$ & NorthAsians & EastAfricans & 0.002038 & 8.38E-04 & 0.014996 \\
\hline$A S I P$ & rs6058017 & G & A & NorthAsians & EastAfricans & 0.001952 & $6.63 \mathrm{E}-04$ & 0.003258 \\
\hline
\end{tabular}




\begin{tabular}{|c|c|c|c|c|c|c|c|c|}
\hline$P I G U$ & rs2378249 & A & G & NorthAsians & EastAfricans & $6.67 \mathrm{E}-04$ & $6.52 \mathrm{E}-04$ & 0.306577 \\
\hline SLC45A2 & rs16891982 & $\mathrm{C}$ & G & NorthAsians & WestAfricans & 0.001087 & $5.44 \mathrm{E}-04$ & 0.045692 \\
\hline SLC45A2 & rs28777 & $\mathrm{C}$ & A & NorthAsians & WestAfricans & $2.00 \mathrm{E}-06$ & $5.19 \mathrm{E}-04$ & 0.997565 \\
\hline SLC45A2 & rs 26722 & $\mathrm{C}$ & $\mathrm{T}$ & NorthAsians & WestAfricans & $6.09 \mathrm{E}-04$ & $5.20 \mathrm{E}-04$ & 0.240886 \\
\hline EXOC2 & rs4959270 & $\mathrm{C}$ & A & NorthAsians & WestAfricans & $1.29 \mathrm{E}-04$ & $5.18 \mathrm{E}-04$ & 0.803923 \\
\hline TYRPI & rs1408799 & $\mathrm{T}$ & $\mathrm{C}$ & NorthAsians & WestAfricans & $-7.09 \mathrm{E}-04$ & $5.36 \mathrm{E}-04$ & 0.185954 \\
\hline TYRPI & rs683 & A & $\mathrm{C}$ & NorthAsians & WestAfricans & $2.45 \mathrm{E}-04$ & $5.26 \mathrm{E}-04$ & 0.641416 \\
\hline$B N C 2$ & rs10756819 & G & A & NorthAsians & WestAfricans & $8.84 \mathrm{E}-04$ & $5.19 \mathrm{E}-04$ & 0.088369 \\
\hline$B N C 2$ & rs12350739 & G & A & NorthAsians & WestAfricans & $6.60 \mathrm{E}-04$ & 5.67E-04 & 0.244361 \\
\hline$D D B 1$ & rs11230664 & $\mathrm{C}$ & $\mathrm{T}$ & NorthAsians & WestAfricans & 0.002097 & $6.71 \mathrm{E}-04$ & 0.001773 \\
\hline$D D B 1$ & rs7120594 & $\mathrm{T}$ & $\mathrm{C}$ & NorthAsians & WestAfricans & 0.00197 & $6.71 \mathrm{E}-04$ & 0.003326 \\
\hline$D D B 1$ & rs7948623 & A & $\mathrm{T}$ & NorthAsians & WestAfricans & -0.00149 & $6.71 \mathrm{E}-04$ & 0.026434 \\
\hline$D D B 1$ & rs1377457 & $\mathrm{C}$ & A & NorthAsians & WestAfricans & 0.002116 & $6.71 \mathrm{E}-04$ & 0.001611 \\
\hline TPCN2 & rs 35264875 & A & $\mathrm{T}$ & NorthAsians & WestAfricans & $3.46 \mathrm{E}-04$ & $5.46 \mathrm{E}-04$ & 0.525583 \\
\hline TPCN2 & rs3829241 & G & A & NorthAsians & WestAfricans & $8.71 \mathrm{E}-04$ & $5.21 \mathrm{E}-04$ & 0.094207 \\
\hline$T Y R$ & rs1042602 & $\mathrm{C}$ & A & NorthAsians & WestAfricans & $5.24 \mathrm{E}-04$ & $5.59 \mathrm{E}-04$ & 0.348536 \\
\hline$T Y R$ & rs1393350 & G & A & NorthAsians & WestAfricans & $7.78 \mathrm{E}-04$ & $7.15 \mathrm{E}-04$ & 0.276486 \\
\hline$T Y R$ & rs1126809 & G & A & NorthAsians & WestAfricans & $1.87 \mathrm{E}-04$ & $5.95 \mathrm{E}-04$ & 0.752689 \\
\hline KITLG & rs642742 & A & G & NorthAsians & WestAfricans & 0.001333 & $5.20 \mathrm{E}-04$ & 0.010391 \\
\hline KITLG & rs 12821256 & $\mathrm{~T}$ & $\mathrm{C}$ & NorthAsians & WestAfricans & $4.44 \mathrm{E}-04$ & $7.96 \mathrm{E}-04$ & 0.577185 \\
\hline$D C T$ & rs1407995 & $\mathrm{T}$ & $\mathrm{C}$ & NorthAsians & WestAfricans & $-6.74 \mathrm{E}-04$ & $5.18 \mathrm{E}-04$ & 0.193307 \\
\hline$D C T$ & rs2031526 & G & A & NorthAsians & WestAfricans & 0.001135 & $5.19 \mathrm{E}-04$ & 0.028743 \\
\hline SLC24A4 & rs12896399 & G & $\mathrm{T}$ & NorthAsians & WestAfricans & 0.001583 & $5.52 \mathrm{E}-04$ & 0.004124 \\
\hline SLC24A4 & rs2402130 & G & A & NorthAsians & WestAfricans & $7.00 \mathrm{E}-04$ & $5.19 \mathrm{E}-04$ & 0.177234 \\
\hline$O C A 2$ & rs2311843 & $\mathrm{C}$ & $\mathrm{T}$ & NorthAsians & WestAfricans & 0.001468 & $5.21 \mathrm{E}-04$ & 0.004867 \\
\hline OCA2 & rs1800414 & A & G & NorthAsians & WestAfricans & 0.001555 & $6.75 \mathrm{E}-04$ & 0.021184 \\
\hline
\end{tabular}




\begin{tabular}{|c|c|c|c|c|c|c|c|c|}
\hline$O C A 2$ & rs1800404 & $\mathrm{C}$ & $\mathrm{T}$ & NorthAsians & WestAfricans & 0.001201 & $5.20 \mathrm{E}-04$ & 0.020896 \\
\hline$O C A 2$ & rs1800401 & $\mathrm{C}$ & $\mathrm{T}$ & NorthAsians & WestAfricans & $-5.74 \mathrm{E}-04$ & $5.31 \mathrm{E}-04$ & 0.280179 \\
\hline HERC2 & rs1129038 & $\mathrm{G}$ & A & NorthAsians & WestAfricans & $2.35 \mathrm{E}-04$ & $5.67 \mathrm{E}-04$ & 0.678681 \\
\hline HERC2 & rs 12913832 & A & $\mathrm{G}$ & NorthAsians & WestAfricans & $2.35 \mathrm{E}-04$ & $5.67 \mathrm{E}-04$ & 0.678681 \\
\hline HERC2 & rs916977 & A & G & NorthAsians & WestAfricans & 4.95E-04 & $5.19 \mathrm{E}-04$ & 0.33946 \\
\hline$H E R C 2$ & rs1667394 & G & A & NorthAsians & WestAfricans & $5.38 \mathrm{E}-04$ & $5.19 \mathrm{E}-04$ & 0.30001 \\
\hline$S L C 24 A 5$ & rs1426654 & G & $\mathrm{A}$ & NorthAsians & WestAfricans & $3.62 \mathrm{E}-04$ & $5.21 \mathrm{E}-04$ & 0.486252 \\
\hline MYO5A & rs4776053 & $\mathrm{C}$ & $\mathrm{T}$ & NorthAsians & WestAfricans & $5.67 \mathrm{E}-04$ & $5.18 \mathrm{E}-04$ & 0.273699 \\
\hline$M C 1 R$ & rs2228479 & G & $\mathrm{A}$ & NorthAsians & WestAfricans & 0.00204 & $6.72 \mathrm{E}-04$ & 0.002397 \\
\hline$M C 1 R$ & rs885479 & G & A & NorthAsians & WestAfricans & 0.002462 & $6.72 \mathrm{E}-04$ & $2.46 \mathrm{E}-04$ \\
\hline MFSD12 & rs56203814 & $\mathrm{C}$ & $\mathrm{T}$ & NorthAsians & WestAfricans & -0.001463 & $6.71 \mathrm{E}-04$ & 0.029258 \\
\hline MFSD 12 & rs 10424065 & $\mathrm{C}$ & $\mathrm{T}$ & NorthAsians & WestAfricans & -0.001619 & $6.71 \mathrm{E}-04$ & 0.01582 \\
\hline MFSD 12 & rs6510760 & G & A & NorthAsians & WestAfricans & -0.001475 & $5.24 \mathrm{E}-04$ & 0.004891 \\
\hline MFSD 12 & rs112332856 & $\mathrm{T}$ & $\mathrm{C}$ & NorthAsians & WestAfricans & -0.001961 & 5.73E-04 & 6.16E-04 \\
\hline$A S I P$ & rs6119471 & G & $\mathrm{C}$ & NorthAsians & WestAfricans & 0.002184 & $6.71 \mathrm{E}-04$ & 0.001134 \\
\hline$A S I P$ & rs6058017 & G & A & NorthAsians & WestAfricans & 0.001673 & $5.36 \mathrm{E}-04$ & 0.001802 \\
\hline$P I G U$ & rs2378249 & A & G & NorthAsians & WestAfricans & $1.95 \mathrm{E}-04$ & $5.18 \mathrm{E}-04$ & 0.707335 \\
\hline SLC45A2 & rs16891982 & $\mathrm{C}$ & $\mathrm{G}$ & Oceanians & EastAsians & 0.001089 & $6.67 \mathrm{E}-04$ & 0.102701 \\
\hline SLC45A2 & rs28777 & $\mathrm{C}$ & A & Oceanians & EastAsians & $8.66 \mathrm{E}-04$ & $6.28 \mathrm{E}-04$ & 0.167747 \\
\hline SLC45A2 & rs26722 & $\mathrm{C}$ & $\mathrm{T}$ & Oceanians & EastAsians & $-3.81 \mathrm{E}-04$ & $6.32 \mathrm{E}-04$ & 0.546907 \\
\hline EXOC2 & rs4959270 & $\mathrm{C}$ & $\mathrm{A}$ & Oceanians & EastAsians & 0.001306 & $6.43 \mathrm{E}-04$ & 0.042308 \\
\hline TYRPI & rs1408799 & $\mathrm{T}$ & $\mathrm{C}$ & Oceanians & EastAsians & $8.90 \mathrm{E}-05$ & $7.45 \mathrm{E}-04$ & 0.904817 \\
\hline$T Y R P 1$ & rs683 & A & $\mathrm{C}$ & Oceanians & EastAsians & $-4.27 \mathrm{E}-04$ & 7.49E-04 & 0.568553 \\
\hline$B N C 2$ & rs 10756819 & G & A & Oceanians & EastAsians & $-1.10 \mathrm{E}-04$ & $6.27 \mathrm{E}-04$ & 0.860449 \\
\hline$B N C 2$ & rs 12350739 & G & A & Oceanians & EastAsians & $1.45 \mathrm{E}-04$ & $9.51 \mathrm{E}-04$ & 0.8785 \\
\hline$D D B 1$ & rs11230664 & $\mathrm{C}$ & $\mathrm{T}$ & Oceanians & EastAsians & -0.001606 & $6.30 \mathrm{E}-04$ & 0.010798 \\
\hline
\end{tabular}




\begin{tabular}{|c|c|c|c|c|c|c|c|c|}
\hline$D D B 1$ & rs7120594 & $\mathrm{T}$ & $\mathrm{C}$ & Oceanians & EastAsians & -0.001606 & $6.30 \mathrm{E}-04$ & 0.010798 \\
\hline$D D B 1$ & rs7948623 & A & $\mathrm{T}$ & Oceanians & EastAsians & 0.002989 & $6.82 \mathrm{E}-04$ & 1.20E-05 \\
\hline$D D B 1$ & rs1377457 & $\mathrm{C}$ & A & Oceanians & EastAsians & -0.002425 & $6.42 \mathrm{E}-04$ & $1.59 \mathrm{E}-04$ \\
\hline TPCN2 & rs 35264875 & A & $\mathrm{T}$ & Oceanians & EastAsians & 0.002225 & $6.40 \mathrm{E}-04$ & 5.03E-04 \\
\hline TPCN2 & rs3829241 & G & A & Oceanians & EastAsians & $-7.46 \mathrm{E}-04$ & $6.73 \mathrm{E}-04$ & 0.267951 \\
\hline$T Y R$ & rs1042602 & $\mathrm{C}$ & A & Oceanians & EastAsians & 8.89E-04 & $9.91 \mathrm{E}-04$ & 0.369733 \\
\hline$T Y R$ & rs1393350 & G & A & Oceanians & EastAsians & 7.20E-04 & $9.76 \mathrm{E}-04$ & 0.460701 \\
\hline$T Y R$ & rs1126809 & G & A & Oceanians & EastAsians & 0.001144 & 0.001024 & 0.26368 \\
\hline KITLG & rs642742 & A & G & Oceanians & EastAsians & $2.10 \mathrm{E}-05$ & 6.34E-04 & 0.973094 \\
\hline KITLG & rs12821256 & $\mathrm{T}$ & $\mathrm{C}$ & Oceanians & EastAsians & 0.001144 & 0.001024 & 0.26368 \\
\hline$D C T$ & rs1407995 & $\mathrm{T}$ & $\mathrm{C}$ & Oceanians & EastAsians & $6.52 \mathrm{E}-04$ & $6.28 \mathrm{E}-04$ & 0.298811 \\
\hline$D C T$ & rs2031526 & G & A & Oceanians & EastAsians & $-6.56 \mathrm{E}-04$ & $6.28 \mathrm{E}-04$ & 0.295756 \\
\hline$S L C 24 A 4$ & rs12896399 & G & $\mathrm{T}$ & Oceanians & EastAsians & $5.03 \mathrm{E}-04$ & $6.28 \mathrm{E}-04$ & 0.422541 \\
\hline SLC24A4 & rs2402130 & G & A & Oceanians & EastAsians & $-5.17 \mathrm{E}-04$ & $6.40 \mathrm{E}-04$ & 0.418887 \\
\hline$O C A 2$ & rs2311843 & $\mathrm{C}$ & $\mathrm{T}$ & Oceanians & EastAsians & $-5.32 \mathrm{E}-04$ & $6.28 \mathrm{E}-04$ & 0.396381 \\
\hline$O C A 2$ & rs1800414 & A & G & Oceanians & EastAsians & $-8.29 \mathrm{E}-04$ & 6.33E-04 & 0.190345 \\
\hline$O C A 2$ & rs1800404 & $\mathrm{C}$ & $\mathrm{T}$ & Oceanians & EastAsians & $-1.68 \mathrm{E}-04$ & $6.29 \mathrm{E}-04$ & 0.789951 \\
\hline$O C A 2$ & rs1800401 & $\mathrm{C}$ & $\mathrm{T}$ & Oceanians & EastAsians & $2.40 \mathrm{E}-05$ & $9.48 \mathrm{E}-04$ & 0.979833 \\
\hline HERC2 & rs1129038 & G & A & Oceanians & EastAsians & $5.94 \mathrm{E}-04$ & $9.68 \mathrm{E}-04$ & 0.539336 \\
\hline HERC2 & rs12913832 & A & G & Oceanians & EastAsians & 7.20E-04 & $9.76 \mathrm{E}-04$ & 0.460701 \\
\hline HERC2 & rs916977 & A & G & Oceanians & EastAsians & $4.50 \mathrm{E}-04$ & $6.27 \mathrm{E}-04$ & 0.473124 \\
\hline HERC2 & rs1667394 & G & A & Oceanians & EastAsians & $4.51 \mathrm{E}-04$ & $6.27 \mathrm{E}-04$ & 0.471789 \\
\hline SLC24A5 & rs1426654 & G & A & Oceanians & EastAsians & $3.31 \mathrm{E}-04$ & 7.48E-04 & 0.658389 \\
\hline MYO5A & rs4776053 & $\mathrm{C}$ & $\mathrm{T}$ & Oceanians & EastAsians & -0.001076 & 7.41E-04 & 0.146351 \\
\hline$M C 1 R$ & rs2228479 & G & A & Oceanians & EastAsians & $-6.02 \mathrm{E}-04$ & $6.47 \mathrm{E}-04$ & 0.351911 \\
\hline$M C 1 R$ & rs885479 & G & A & Oceanians & EastAsians & -0.00184 & $6.94 \mathrm{E}-04$ & 0.008036 \\
\hline
\end{tabular}




\begin{tabular}{|c|c|c|c|c|c|c|c|c|}
\hline MFSD12 & rs56203814 & $\mathrm{C}$ & $\mathrm{T}$ & Oceanians & EastAsians & 0.001694 & 0.001175 & 0.149534 \\
\hline MFSD12 & rs 10424065 & $\mathrm{C}$ & $\mathrm{T}$ & Oceanians & EastAsians & 0.001144 & 0.001024 & 0.26368 \\
\hline MFSD12 & rs6510760 & G & A & Oceanians & EastAsians & 0.001475 & $6.29 \mathrm{E}-04$ & 0.019026 \\
\hline MFSD12 & rs112332856 & $\mathrm{T}$ & $\mathrm{C}$ & Oceanians & EastAsians & 0.002203 & $6.52 \mathrm{E}-04$ & 7.21E-04 \\
\hline$A S I P$ & rs6119471 & G & $\mathrm{C}$ & Oceanians & EastAsians & -0.001694 & 0.001175 & 0.149534 \\
\hline$A S I P$ & rs6058017 & G & A & Oceanians & EastAsians & $2.40 \mathrm{E}-04$ & $6.38 \mathrm{E}-04$ & 0.707433 \\
\hline$P I G U$ & rs2378249 & A & G & Oceanians & EastAsians & $-1.03 \mathrm{E}-04$ & $6.41 \mathrm{E}-04$ & 0.872447 \\
\hline$S L C 45 A 2$ & rs16891982 & $\mathrm{C}$ & G & Oceanians & EastAfricans & 7.26E-04 & 7.29E-04 & 0.318758 \\
\hline$S L C 45 A 2$ & rs28777 & $\mathrm{C}$ & A & Oceanians & EastAfricans & $3.35 \mathrm{E}-04$ & $6.44 \mathrm{E}-04$ & 0.603448 \\
\hline$S L C 45 A 2$ & rs26722 & $\mathrm{C}$ & $\mathrm{T}$ & Oceanians & EastAfricans & $6.08 \mathrm{E}-04$ & $6.59 \mathrm{E}-04$ & 0.356442 \\
\hline EXOC2 & rs4959270 & $\mathrm{C}$ & A & Oceanians & EastAfricans & 0.001811 & $6.65 \mathrm{E}-04$ & 0.006465 \\
\hline TYRPI & rs1408799 & $\mathrm{T}$ & $\mathrm{C}$ & Oceanians & EastAfricans & $-9.88 \mathrm{E}-04$ & 7.12E-04 & 0.164947 \\
\hline$T Y R P 1$ & rs683 & A & $\mathrm{C}$ & Oceanians & EastAfricans & 8.92E-04 & 7.13E-04 & 0.210637 \\
\hline$B N C 2$ & rs 10756819 & G & A & Oceanians & EastAfricans & 0.001476 & $6.84 \mathrm{E}-04$ & 0.031069 \\
\hline$B N C 2$ & rs 12350739 & G & A & Oceanians & EastAfricans & 2.35E-04 & 9.97E-04 & 0.813429 \\
\hline$D D B 1$ & rs11230664 & $\mathrm{C}$ & $\mathrm{T}$ & Oceanians & EastAfricans & 0.001111 & $6.56 \mathrm{E}-04$ & 0.090412 \\
\hline$D D B 1$ & rs7120594 & $\mathrm{T}$ & $\mathrm{C}$ & Oceanians & EastAfricans & 5.94E-04 & $6.45 \mathrm{E}-04$ & 0.357396 \\
\hline$D D B 1$ & rs7948623 & A & $\mathrm{T}$ & Oceanians & EastAfricans & $-3.64 \mathrm{E}-04$ & $6.43 \mathrm{E}-04$ & 0.57195 \\
\hline$D D B 1$ & rs1377457 & $\mathrm{C}$ & A & Oceanians & EastAfricans & 0.001174 & $6.59 \mathrm{E}-04$ & 0.074815 \\
\hline TPCN2 & rs 35264875 & A & $\mathrm{T}$ & Oceanians & EastAfricans & $4.90 \mathrm{E}-04$ & $6.46 \mathrm{E}-04$ & 0.448032 \\
\hline TPCN2 & rs3829241 & G & A & Oceanians & EastAfricans & $3.77 \mathrm{E}-04$ & 7.10E-04 & 0.59576 \\
\hline$T Y R$ & rs1042602 & $\mathrm{C}$ & A & Oceanians & EastAfricans & $2.35 \mathrm{E}-04$ & $9.97 \mathrm{E}-04$ & 0.813429 \\
\hline$T Y R$ & rs1393350 & G & A & Oceanians & EastAfricans & $2.35 \mathrm{E}-04$ & 9.97E-04 & 0.813429 \\
\hline$T Y R$ & rs1126809 & G & A & Oceanians & EastAfricans & $2.35 \mathrm{E}-04$ & $9.97 \mathrm{E}-04$ & 0.813429 \\
\hline KITLG & rs642742 & A & G & Oceanians & EastAfricans & 0.001297 & $6.52 \mathrm{E}-04$ & 0.04667 \\
\hline KITLG & rs 12821256 & $\mathrm{~T}$ & $\mathrm{C}$ & Oceanians & EastAfricans & $-8.58 \mathrm{E}-04$ & 8.47E-04 & 0.310831 \\
\hline
\end{tabular}




\begin{tabular}{|c|c|c|c|c|c|c|c|c|}
\hline$D C T$ & rs1407995 & $\mathrm{T}$ & $\mathrm{C}$ & Oceanians & EastAfricans & $-5.38 \mathrm{E}-04$ & $6.46 \mathrm{E}-04$ & 0.404862 \\
\hline$D C T$ & rs2031526 & G & A & Oceanians & EastAfricans & 0.001103 & $6.63 \mathrm{E}-04$ & 0.096146 \\
\hline SLC $24 A 4$ & rs12896399 & G & $\mathrm{T}$ & Oceanians & EastAfricans & 0.001184 & $6.56 \mathrm{E}-04$ & 0.071209 \\
\hline SLC $24 A 4$ & rs2402130 & G & A & Oceanians & EastAfricans & $6.62 \mathrm{E}-04$ & $6.49 \mathrm{E}-04$ & 0.308068 \\
\hline$O C A 2$ & rs2311843 & $\mathrm{C}$ & $\mathrm{T}$ & Oceanians & EastAfricans & 0.001748 & 7.13E-04 & 0.014191 \\
\hline$O C A 2$ & rs1800414 & A & G & Oceanians & EastAfricans & 0.001612 & $8.42 \mathrm{E}-04$ & 0.055664 \\
\hline$O C A 2$ & rs1800404 & $\mathrm{C}$ & $\mathrm{T}$ & Oceanians & EastAfricans & $9.40 \mathrm{E}-04$ & $6.66 \mathrm{E}-04$ & 0.158276 \\
\hline$O C A 2$ & rs1800401 & $\mathrm{C}$ & $\mathrm{T}$ & Oceanians & EastAfricans & $-6.23 \mathrm{E}-04$ & $8.55 \mathrm{E}-04$ & 0.466227 \\
\hline HERC2 & rs1129038 & G & A & Oceanians & EastAfricans & $2.35 \mathrm{E}-04$ & 9.97E-04 & 0.813429 \\
\hline HERC2 & rs 12913832 & A & G & Oceanians & EastAfricans & $2.35 \mathrm{E}-04$ & 9.97E-04 & 0.813429 \\
\hline HERC2 & rs916977 & A & G & Oceanians & EastAfricans & 0.001428 & $6.85 \mathrm{E}-04$ & 0.036998 \\
\hline HERC2 & rs1667394 & G & A & Oceanians & EastAfricans & 0.001428 & $6.85 \mathrm{E}-04$ & 0.036998 \\
\hline SLC24A5 & rs1426654 & G & A & Oceanians & EastAfricans & $-9.40 \mathrm{E}-05$ & 7.37E-04 & 0.898072 \\
\hline MYO5A & rs4776053 & $\mathrm{C}$ & $\mathrm{T}$ & Oceanians & EastAfricans & $-3.75 \mathrm{E}-04$ & 7.23E-04 & 0.604181 \\
\hline$M C 1 R$ & rs2228479 & G & A & Oceanians & EastAfricans & 0.001295 & $8.48 \mathrm{E}-04$ & 0.126915 \\
\hline$M C 1 R$ & rs885479 & G & A & Oceanians & EastAfricans & 8.67E-04 & 8.70E-04 & 0.319434 \\
\hline MFSD12 & rs56203814 & $\mathrm{C}$ & $\mathrm{T}$ & Oceanians & EastAfricans & -0.001207 & 8.41E-04 & 0.151188 \\
\hline MFSD12 & rs 10424065 & $\mathrm{C}$ & $\mathrm{T}$ & Oceanians & EastAfricans & -0.002011 & 8.38E-04 & 0.016387 \\
\hline MFSD12 & rs6510760 & G & A & Oceanians & EastAfricans & -0.001219 & $6.65 \mathrm{E}-04$ & 0.066782 \\
\hline MFSD12 & rs112332856 & $\mathrm{T}$ & $\mathrm{C}$ & Oceanians & EastAfricans & -0.001604 & $6.67 \mathrm{E}-04$ & 0.016127 \\
\hline$A S I P$ & rs6119471 & G & $\mathrm{C}$ & Oceanians & EastAfricans & 0.00155 & 8.38E-04 & 0.06457 \\
\hline$A S I P$ & rs6058017 & G & A & Oceanians & EastAfricans & 0.001098 & $6.51 \mathrm{E}-04$ & 0.091568 \\
\hline$P I G U$ & rs2378249 & A & G & Oceanians & EastAfricans & $3.67 \mathrm{E}-04$ & $6.64 \mathrm{E}-04$ & 0.580531 \\
\hline SLC45A2 & rs16891982 & $\mathrm{C}$ & $\mathrm{G}$ & Oceanians & WestAfricans & $9.61 \mathrm{E}-04$ & $5.60 \mathrm{E}-04$ & 0.086576 \\
\hline SLC45A2 & rs28777 & $\mathrm{C}$ & A & Oceanians & WestAfricans & 4.33E-04 & $5.24 \mathrm{E}-04$ & 0.408818 \\
\hline$S L C 45 A 2$ & rs 26722 & $\mathrm{C}$ & $\mathrm{T}$ & Oceanians & WestAfricans & $5.63 \mathrm{E}-04$ & $5.27 \mathrm{E}-04$ & 0.286 \\
\hline
\end{tabular}




\begin{tabular}{|c|c|c|c|c|c|c|c|c|}
\hline EXOC2 & rs4959270 & $\mathrm{C}$ & A & Oceanians & WestAfricans & 9.84E-04 & 5.31E-04 & 0.063704 \\
\hline TYRPI & rs1408799 & $\mathrm{T}$ & $\mathrm{C}$ & Oceanians & WestAfricans & $-6.57 E-04$ & $5.76 \mathrm{E}-04$ & 0.253421 \\
\hline TYRPI & rs683 & A & $\mathrm{C}$ & Oceanians & WestAfricans & $4.44 \mathrm{E}-04$ & $5.76 \mathrm{E}-04$ & 0.441185 \\
\hline$B N C 2$ & rs10756819 & G & A & Oceanians & WestAfricans & 8.03E-04 & $5.25 \mathrm{E}-04$ & 0.125638 \\
\hline$B N C 2$ & rs12350739 & G & A & Oceanians & WestAfricans & $3.40 \mathrm{E}-04$ & 7.00E-04 & 0.626702 \\
\hline$D D B 1$ & rs11230664 & $\mathrm{C}$ & $\mathrm{T}$ & Oceanians & WestAfricans & 2.80E-04 & 5.24E-04 & 0.592903 \\
\hline$D D B 1$ & rs7120594 & $\mathrm{T}$ & $\mathrm{C}$ & Oceanians & WestAfricans & $1.52 \mathrm{E}-04$ & $5.23 \mathrm{E}-04$ & 0.771004 \\
\hline$D D B 1$ & rs7948623 & A & $\mathrm{T}$ & Oceanians & WestAfricans & $2.70 \mathrm{E}-04$ & $5.24 \mathrm{E}-04$ & 0.605794 \\
\hline$D D B 1$ & rs1377457 & $\mathrm{C}$ & A & Oceanians & WestAfricans & 2.99E-04 & $5.24 \mathrm{E}-04$ & 0.568196 \\
\hline TPCN2 & rs35264875 & A & $\mathrm{T}$ & Oceanians & WestAfricans & 0.001402 & $5.36 \mathrm{E}-04$ & 0.008884 \\
\hline TPCN2 & rs3829241 & G & A & Oceanians & WestAfricans & $2.27 \mathrm{E}-04$ & $5.47 \mathrm{E}-04$ & 0.677517 \\
\hline$T Y R$ & rs1042602 & $\mathrm{C}$ & A & Oceanians & WestAfricans & 2.38E-04 & $6.92 \mathrm{E}-04$ & 0.730883 \\
\hline$T Y R$ & rs1393350 & G & A & Oceanians & WestAfricans & 8.29E-04 & $7.98 \mathrm{E}-04$ & 0.299012 \\
\hline$T Y R$ & rs1126809 & G & A & Oceanians & WestAfricans & 2.38E-04 & $6.92 \mathrm{E}-04$ & 0.730883 \\
\hline KITLG & rs642742 & A & G & Oceanians & WestAfricans & 0.001175 & $5.27 \mathrm{E}-04$ & 0.025836 \\
\hline KITLG & rs 12821256 & $\mathrm{~T}$ & $\mathrm{C}$ & Oceanians & WestAfricans & 8.29E-04 & $7.98 \mathrm{E}-04$ & 0.299012 \\
\hline$D C T$ & rs1407995 & $\mathrm{T}$ & $\mathrm{C}$ & Oceanians & WestAfricans & $-3.25 \mathrm{E}-04$ & $5.24 \mathrm{E}-04$ & 0.534328 \\
\hline$D C T$ & rs2031526 & G & A & Oceanians & WestAfricans & $7.87 \mathrm{E}-04$ & $5.25 \mathrm{E}-04$ & 0.133799 \\
\hline$S L C 24 A 4$ & rs12896399 & G & $\mathrm{T}$ & Oceanians & WestAfricans & 0.001906 & $5.57 \mathrm{E}-04$ & $6.26 \mathrm{E}-04$ \\
\hline SLC24A4 & rs2402130 & G & A & Oceanians & WestAfricans & $6.51 \mathrm{E}-04$ & $5.28 \mathrm{E}-04$ & 0.217798 \\
\hline$O C A 2$ & rs2311843 & $\mathrm{C}$ & $\mathrm{T}$ & Oceanians & WestAfricans & 0.001163 & $5.27 \mathrm{E}-04$ & 0.027279 \\
\hline$O C A 2$ & rs1800414 & A & G & Oceanians & WestAfricans & 0.001913 & $6.78 \mathrm{E}-04$ & 0.004789 \\
\hline$O C A 2$ & rs1800404 & $\mathrm{C}$ & $\mathrm{T}$ & Oceanians & WestAfricans & $3.90 \mathrm{E}-04$ & $5.25 \mathrm{E}-04$ & 0.457676 \\
\hline OCA2 & rs1800401 & $\mathrm{C}$ & $\mathrm{T}$ & Oceanians & WestAfricans & $-9.50 \mathrm{E}-04$ & $6.74 \mathrm{E}-04$ & 0.158555 \\
\hline HERC2 & rs1129038 & G & A & Oceanians & WestAfricans & $1.29 \mathrm{E}-04$ & $6.87 \mathrm{E}-04$ & 0.850487 \\
\hline HERC2 & rs 12913832 & A & G & Oceanians & WestAfricans & $1.29 \mathrm{E}-04$ & $6.87 \mathrm{E}-04$ & 0.850487 \\
\hline
\end{tabular}




\begin{tabular}{|c|c|c|c|c|c|c|c|c|}
\hline HERC2 & rs916977 & A & G & Oceanians & WestAfricans & 7.23E-04 & 5.24E-04 & 0.167892 \\
\hline HERC2 & rs1667394 & G & A & Oceanians & WestAfricans & $7.65 \mathrm{E}-04$ & $5.25 \mathrm{E}-04$ & 0.144519 \\
\hline SLC24A5 & rs1426654 & G & A & Oceanians & WestAfricans & $-2.32 \mathrm{E}-04$ & $5.77 \mathrm{E}-04$ & 0.687656 \\
\hline MYO5A & rs4776053 & $\mathrm{C}$ & $\mathrm{T}$ & Oceanians & WestAfricans & $-3.85 \mathrm{E}-04$ & $5.76 \mathrm{E}-04$ & 0.504393 \\
\hline$M C 1 R$ & rs2228479 & G & A & Oceanians & WestAfricans & 0.001664 & $6.83 \mathrm{E}-04$ & 0.014853 \\
\hline$M C 1 R$ & rs885479 & G & A & Oceanians & WestAfricans & 0.001326 & $7.00 \mathrm{E}-04$ & 0.05814 \\
\hline MFSD12 & rs56203814 & $\mathrm{C}$ & $\mathrm{T}$ & Oceanians & WestAfricans & -0.001078 & 6.73E-04 & 0.109476 \\
\hline MFSD 12 & rs 10424065 & $\mathrm{C}$ & $\mathrm{T}$ & Oceanians & WestAfricans & -0.001234 & $6.73 \mathrm{E}-04$ & 0.066848 \\
\hline MFSD12 & rs6510760 & G & A & Oceanians & WestAfricans & $-5.80 \mathrm{E}-04$ & $5.24 \mathrm{E}-04$ & 0.268324 \\
\hline MFSD 12 & rs112332856 & $\mathrm{T}$ & $\mathrm{C}$ & Oceanians & WestAfricans & $-7.24 \mathrm{E}-04$ & $5.25 \mathrm{E}-04$ & 0.167624 \\
\hline$A S I P$ & rs6119471 & G & $\mathrm{C}$ & Oceanians & WestAfricans & 0.001799 & $6.73 \mathrm{E}-04$ & 0.007547 \\
\hline$A S I P$ & rs6058017 & G & A & Oceanians & WestAfricans & 9.99E-04 & $5.29 \mathrm{E}-04$ & 0.058665 \\
\hline$P I G U$ & rs2378249 & A & G & Oceanians & WestAfricans & $-4.20 \mathrm{E}-05$ & $5.30 \mathrm{E}-04$ & 0.936817 \\
\hline SLC45A2 & rs16891982 & $\mathrm{C}$ & G & EastAsians & EastAfricans & $-1.11 \mathrm{E}-04$ & 7.02E-04 & 0.873917 \\
\hline$S L C 45 A 2$ & rs28777 & $\mathrm{C}$ & A & EastAsians & EastAfricans & $-3.32 \mathrm{E}-04$ & $6.27 \mathrm{E}-04$ & 0.596567 \\
\hline SLC45A2 & rs 26722 & $\mathrm{C}$ & $\mathrm{T}$ & EastAsians & EastAfricans & $9.01 \mathrm{E}-04$ & 6.39E-04 & 0.158605 \\
\hline ЕХOC2 & rs4959270 & $\mathrm{C}$ & A & EastAsians & EastAfricans & 8.07E-04 & 6.39E-04 & 0.206507 \\
\hline TYRPI & rs1408799 & $\mathrm{T}$ & $\mathrm{C}$ & EastAsians & EastAfricans & -0.001057 & $6.29 \mathrm{E}-04$ & 0.093125 \\
\hline$T Y R P 1$ & rs683 & A & $\mathrm{C}$ & EastAsians & EastAfricans & 0.001221 & 6.33E-04 & 0.053946 \\
\hline$B N C 2$ & rs 10756819 & G & A & EastAsians & EastAfricans & 0.001561 & $6.68 \mathrm{E}-04$ & 0.019443 \\
\hline$B N C 2$ & rs12350739 & G & A & EastAsians & EastAfricans & $1.24 \mathrm{E}-04$ & 8.34E-04 & 0.882304 \\
\hline$D D B 1$ & rs11230664 & $\mathrm{C}$ & $\mathrm{T}$ & EastAsians & EastAfricans & 0.002346 & $6.40 \mathrm{E}-04$ & 2.48E-04 \\
\hline$D D B 1$ & rs7120594 & $\mathrm{T}$ & $\mathrm{C}$ & EastAsians & EastAfricans & 0.001829 & $6.29 \mathrm{E}-04$ & 0.003637 \\
\hline$D D B 1$ & rs7948623 & A & $\mathrm{T}$ & EastAsians & EastAfricans & -0.002662 & $6.58 \mathrm{E}-04$ & $5.20 \mathrm{E}-05$ \\
\hline$D D B 1$ & rs1377457 & $\mathrm{C}$ & A & EastAsians & EastAfricans & 0.003039 & $6.50 \mathrm{E}-04$ & 3.00E-06 \\
\hline TPCN2 & rs35264875 & A & $\mathrm{T}$ & EastAsians & EastAfricans & -0.001222 & $6.35 \mathrm{E}-04$ & 0.05446 \\
\hline
\end{tabular}




\begin{tabular}{|c|c|c|c|c|c|c|c|c|}
\hline TPCN2 & rs3829241 & $\mathrm{G}$ & A & EastAsians & EastAfricans & $9.51 \mathrm{E}-04$ & $6.68 \mathrm{E}-04$ & 0.154736 \\
\hline$T Y R$ & rs1042602 & $\mathrm{C}$ & A & EastAsians & EastAfricans & $-4.48 \mathrm{E}-04$ & 8.61E-04 & 0.602762 \\
\hline$T Y R$ & rs1393350 & G & A & EastAsians & EastAfricans & $-3.19 \mathrm{E}-04$ & $8.51 \mathrm{E}-04$ & 0.708248 \\
\hline$T Y R$ & rs1126809 & G & A & EastAsians & EastAfricans & $-6.45 \mathrm{E}-04$ & 8.84E-04 & 0.465599 \\
\hline KITLG & rs642742 & A & G & EastAsians & EastAfricans & 0.001281 & $6.31 \mathrm{E}-04$ & 0.0423 \\
\hline KITLG & rs 12821256 & $\mathrm{~T}$ & $\mathrm{C}$ & EastAsians & EastAfricans & -0.001738 & $7.10 \mathrm{E}-04$ & 0.014326 \\
\hline$D C T$ & rs1407995 & $\mathrm{T}$ & $\mathrm{C}$ & EastAsians & EastAfricans & -0.00104 & $6.28 \mathrm{E}-04$ & 0.098027 \\
\hline$D C T$ & rs2031526 & G & A & EastAsians & EastAfricans & 0.001607 & $6.45 \mathrm{E}-04$ & 0.012763 \\
\hline$S L C 24 A 4$ & rs 12896399 & $\mathrm{G}$ & $\mathrm{T}$ & EastAsians & EastAfricans & 7.97E-04 & $6.39 \mathrm{E}-04$ & 0.212191 \\
\hline SLC24A4 & rs2402130 & G & A & EastAsians & EastAfricans & 0.001059 & $6.26 \mathrm{E}-04$ & 0.090478 \\
\hline$O C A 2$ & rs2311843 & $\mathrm{C}$ & $\mathrm{T}$ & EastAsians & EastAfricans & 0.002157 & $6.97 \mathrm{E}-04$ & 0.001962 \\
\hline$O C A 2$ & rs1800414 & A & G & EastAsians & EastAfricans & 0.002249 & $8.26 \mathrm{E}-04$ & 0.006478 \\
\hline$O C A 2$ & rs1800404 & $\mathrm{C}$ & $\mathrm{T}$ & EastAsians & EastAfricans & 0.001069 & $6.48 \mathrm{E}-04$ & 0.099004 \\
\hline$O C A 2$ & rs1800401 & $\mathrm{C}$ & $\mathrm{T}$ & EastAsians & EastAfricans & $-6.41 \mathrm{E}-04$ & $6.56 \mathrm{E}-04$ & 0.327988 \\
\hline HERC2 & rs1129038 & G & A & EastAsians & EastAfricans & $-2.22 \mathrm{E}-04$ & $8.46 \mathrm{E}-04$ & 0.79322 \\
\hline HERC2 & rs12913832 & A & G & EastAsians & EastAfricans & $-3.19 \mathrm{E}-04$ & 8.51E-04 & 0.708248 \\
\hline HERC2 & rs916977 & A & G & EastAsians & EastAfricans & 0.001082 & $6.68 \mathrm{E}-04$ & 0.105386 \\
\hline HERC2 & rs1667394 & G & A & EastAsians & EastAfricans & 0.00108 & $6.68 \mathrm{E}-04$ & 0.105724 \\
\hline$S L C 24 A 5$ & rs1426654 & G & A & EastAsians & EastAfricans & $-3.49 \mathrm{E}-04$ & $6.60 \mathrm{E}-04$ & 0.597169 \\
\hline MYO5A & rs4776053 & $\mathrm{C}$ & $\mathrm{T}$ & EastAsians & EastAfricans & $4.53 \mathrm{E}-04$ & $6.39 \mathrm{E}-04$ & 0.478246 \\
\hline$M C 1 R$ & rs2228479 & G & A & EastAsians & EastAfricans & 0.001758 & $8.26 \mathrm{E}-04$ & $\mathbf{0 . 0 3 3 3 8 7}$ \\
\hline$M C 1 R$ & rs 885479 & G & A & EastAsians & EastAfricans & 0.002282 & $8.26 \mathrm{E}-04$ & 0.005752 \\
\hline MFSD12 & rs56203814 & $\mathrm{C}$ & $\mathrm{T}$ & EastAsians & EastAfricans & -0.00251 & 8.31E-04 & $\mathbf{0 . 0 0 2 5 3 4}$ \\
\hline MFSD12 & rs 10424065 & $\mathrm{C}$ & $\mathrm{T}$ & EastAsians & EastAfricans & -0.002891 & $6.99 \mathrm{E}-04$ & 3.60E-05 \\
\hline MFSD12 & rs6510760 & G & A & EastAsians & EastAfricans & -0.002354 & $6.49 \mathrm{E}-04$ & 2.86E-04 \\
\hline MFSD12 & rs112332856 & $\mathrm{T}$ & $\mathrm{C}$ & EastAsians & EastAfricans & -0.003299 & $6.60 \mathrm{E}-04$ & $1.00 \mathrm{E}-06$ \\
\hline
\end{tabular}




\begin{tabular}{|c|c|c|c|c|c|c|c|c|}
\hline$A S I P$ & rs6119471 & G & $\mathrm{C}$ & EastAsians & EastAfricans & 0.002852 & 8.29E-04 & 5.79E-04 \\
\hline$A S I P$ & rs6058017 & G & A & EastAsians & EastAfricans & $9.13 \mathrm{E}-04$ & $6.27 \mathrm{E}-04$ & 0.144925 \\
\hline$P I G U$ & rs2378249 & A & G & EastAsians & EastAfricans & $4.46 \mathrm{E}-04$ & $6.39 \mathrm{E}-04$ & 0.485309 \\
\hline SLC45A2 & rs16891982 & $\mathrm{C}$ & G & EastAsians & WestAfricans & $3.00 \mathrm{E}-04$ & $5.36 \mathrm{E}-04$ & 0.575049 \\
\hline SLC45A2 & rs 28777 & $\mathrm{C}$ & A & EastAsians & WestAfricans & $-9.20 \mathrm{E}-05$ & $5.07 \mathrm{E}-04$ & 0.85544 \\
\hline SLC45A2 & rs 26722 & $\mathrm{C}$ & $\mathrm{T}$ & EastAsians & WestAfricans & 7.93E-04 & $5.08 \mathrm{E}-04$ & 0.118286 \\
\hline ЕХOC2 & rs4959270 & $\mathrm{C}$ & A & EastAsians & WestAfricans & $1.93 \mathrm{E}-04$ & $5.06 \mathrm{E}-04$ & 0.703733 \\
\hline TYRPI & rs1408799 & $\mathrm{T}$ & $\mathrm{C}$ & EastAsians & WestAfricans & $-7.11 \mathrm{E}-04$ & $5.09 \mathrm{E}-04$ & 0.16208 \\
\hline TYRPI & rs683 & A & $\mathrm{C}$ & EastAsians & WestAfricans & 7.02E-04 & $5.11 \mathrm{E}-04$ & 0.169651 \\
\hline$B N C 2$ & rs 10756819 & G & A & EastAsians & WestAfricans & 8.70E-04 & $5.07 \mathrm{E}-04$ & 0.086276 \\
\hline$B N C 2$ & rs 12350739 & G & A & EastAsians & WestAfricans & $2.52 \mathrm{E}-04$ & $5.48 \mathrm{E}-04$ & 0.64552 \\
\hline$D D B 1$ & rs11230664 & $\mathrm{C}$ & $\mathrm{T}$ & EastAsians & WestAfricans & 0.001253 & $5.07 \mathrm{E}-04$ & 0.013528 \\
\hline$D D B 1$ & rs7120594 & $\mathrm{T}$ & $\mathrm{C}$ & EastAsians & WestAfricans & 0.001126 & 5.07E-04 & 0.026524 \\
\hline$D D B 1$ & rs7948623 & A & $\mathrm{T}$ & EastAsians & WestAfricans & -0.001541 & 5.31E-04 & 0.003738 \\
\hline$D D B 1$ & rs1377457 & $\mathrm{C}$ & A & EastAsians & WestAfricans & 0.001768 & 5.13E-04 & $5.67 \mathrm{E}-04$ \\
\hline TPCN2 & rs 35264875 & A & $\mathrm{T}$ & EastAsians & WestAfricans & $5.30 \mathrm{E}-05$ & $5.24 \mathrm{E}-04$ & 0.919283 \\
\hline TPCN2 & rs3829241 & G & A & EastAsians & WestAfricans & $6.80 \mathrm{E}-04$ & $5.09 \mathrm{E}-04$ & 0.182182 \\
\hline$T Y R$ & rs1042602 & $\mathrm{C}$ & A & EastAsians & WestAfricans & $-3.00 \mathrm{E}-04$ & $5.65 \mathrm{E}-04$ & 0.59469 \\
\hline$T Y R$ & rs1393350 & G & A & EastAsians & WestAfricans & $3.92 \mathrm{E}-04$ & $6.82 \mathrm{E}-04$ & 0.565332 \\
\hline$T Y R$ & rs1126809 & G & A & EastAsians & WestAfricans & $-4.55 \mathrm{E}-04$ & $5.86 \mathrm{E}-04$ & 0.437031 \\
\hline KITLG & rs642742 & A & G & EastAsians & WestAfricans & 0.001162 & $5.07 \mathrm{E}-04$ & 0.021928 \\
\hline KITLG & rs 12821256 & $\mathrm{~T}$ & $\mathrm{C}$ & EastAsians & WestAfricans & $1.35 \mathrm{E}-04$ & $7.08 \mathrm{E}-04$ & 0.8484 \\
\hline$D C T$ & rs1407995 & $\mathrm{T}$ & $\mathrm{C}$ & EastAsians & WestAfricans & $-7.21 \mathrm{E}-04$ & $5.06 \mathrm{E}-04$ & 0.154743 \\
\hline$D C T$ & rs2031526 & G & A & EastAsians & WestAfricans & 0.001185 & $5.08 \mathrm{E}-04$ & 0.019612 \\
\hline SLC24A4 & rs12896399 & G & $\mathrm{T}$ & EastAsians & WestAfricans & 0.001601 & $5.41 \mathrm{E}-04$ & 0.00308 \\
\hline SLC24A4 & rs2402130 & G & A & EastAsians & WestAfricans & $9.65 \mathrm{E}-04$ & $5.07 \mathrm{E}-04$ & 0.057024 \\
\hline
\end{tabular}




\begin{tabular}{|c|c|c|c|c|c|c|c|c|}
\hline$O C A 2$ & rs 2311843 & $\mathrm{C}$ & $\mathrm{T}$ & EastAsians & WestAfricans & 0.001485 & $5.10 \mathrm{E}-04$ & 0.00356 \\
\hline OCA2 & rs1800414 & A & $\mathrm{G}$ & EastAsians & WestAfricans & 0.002416 & $6.63 \mathrm{E}-04$ & 2.69E-04 \\
\hline$O C A 2$ & rs1800404 & $\mathrm{C}$ & $\mathrm{T}$ & EastAsians & WestAfricans & 4.91E-04 & 5.07E-04 & 0.332155 \\
\hline$O C A 2$ & rs1800401 & $\mathrm{C}$ & $\mathrm{T}$ & EastAsians & WestAfricans & $-9.64 \mathrm{E}-04$ & 5.13E-04 & 0.06006 \\
\hline HERC2 & rs1129038 & $\mathrm{G}$ & A & EastAsians & WestAfricans & $-2.31 \mathrm{E}-04$ & $5.43 \mathrm{E}-04$ & 0.670853 \\
\hline HERC2 & rs12913832 & A & $\mathrm{G}$ & EastAsians & WestAfricans & $-3.07 E-04$ & $5.48 \mathrm{E}-04$ & 0.575425 \\
\hline HERC2 & rs916977 & A & G & EastAsians & WestAfricans & $4.50 \mathrm{E}-04$ & $5.07 \mathrm{E}-04$ & 0.374526 \\
\hline HERC2 & rs1667394 & G & A & EastAsians & WestAfricans & 4.92E-04 & $5.07 \mathrm{E}-04$ & 0.332331 \\
\hline$S L C 24 A 5$ & rs1426654 & $\mathrm{G}$ & A & EastAsians & WestAfricans & $-4.32 \mathrm{E}-04$ & $5.12 \mathrm{E}-04$ & 0.398198 \\
\hline MYO5A & rs4776053 & $\mathrm{C}$ & $\mathrm{T}$ & EastAsians & WestAfricans & $2.68 \mathrm{E}-04$ & $5.07 \mathrm{E}-04$ & 0.597823 \\
\hline$M C 1 R$ & rs2228479 & G & A & EastAsians & WestAfricans & 0.002028 & $6.63 \mathrm{E}-04$ & 0.00222 \\
\hline$M C 1 R$ & rs885479 & G & A & EastAsians & WestAfricans & 0.002441 & $6.63 \mathrm{E}-04$ & 2.32E-04 \\
\hline MFSD12 & rs56203814 & $\mathrm{C}$ & $\mathrm{T}$ & EastAsians & WestAfricans & -0.002104 & $6.63 \mathrm{E}-04$ & 0.001509 \\
\hline MFSD12 & rs 10424065 & $\mathrm{C}$ & $\mathrm{T}$ & EastAsians & WestAfricans & -0.001928 & 5.63E-04 & 6.22E-04 \\
\hline MFSD12 & rs6510760 & G & A & EastAsians & WestAfricans & -0.001474 & $5.07 \mathrm{E}-04$ & 0.003679 \\
\hline MFSD12 & rs112332856 & $\mathrm{T}$ & $\mathrm{C}$ & EastAsians & WestAfricans & -0.00206 & $5.16 \mathrm{E}-04$ & $6.60 \mathrm{E}-05$ \\
\hline$A S I P$ & rs6119471 & G & $\mathrm{C}$ & EastAsians & WestAfricans & 0.002826 & 6.63E-04 & $2.00 \mathrm{E}-05$ \\
\hline$A S I P$ & rs6058017 & G & A & EastAsians & WestAfricans & $8.54 \mathrm{E}-04$ & $5.07 \mathrm{E}-04$ & 0.091702 \\
\hline$P I G U$ & rs2378249 & A & $\mathrm{G}$ & EastAsians & WestAfricans & $2.00 \mathrm{E}-05$ & $5.07 \mathrm{E}-04$ & 0.967942 \\
\hline$S L C 45 A 2$ & rs16891982 & $\mathrm{C}$ & G & EastAfricans & WestAfricans & $3.88 \mathrm{E}-04$ & $3.41 \mathrm{E}-04$ & 0.255086 \\
\hline$S L C 45 A 2$ & rs28777 & $\mathrm{C}$ & A & EastAfricans & WestAfricans & 1.69E-04 & $1.81 \mathrm{E}-04$ & 0.351565 \\
\hline$S L C 45 A 2$ & rs26722 & $\mathrm{C}$ & $\mathrm{T}$ & EastAfricans & WestAfricans & $8.40 \mathrm{E}-05$ & $2.10 \mathrm{E}-04$ & 0.689776 \\
\hline EXOC2 & rs4959270 & $\mathrm{C}$ & A & EastAfricans & WestAfricans & $-4.43 \mathrm{E}-04$ & $2.06 \mathrm{E}-04$ & 0.03162 \\
\hline TYRPI & rs1408799 & $\mathrm{T}$ & $\mathrm{C}$ & EastAfricans & WestAfricans & $1.22 \mathrm{E}-04$ & $1.82 \mathrm{E}-04$ & 0.503424 \\
\hline TYRPI & rs683 & A & $\mathrm{C}$ & EastAfricans & WestAfricans & $-2.59 \mathrm{E}-04$ & $1.85 \mathrm{E}-04$ & 0.160278 \\
\hline$B N C 2$ & rs10756819 & $\mathrm{G}$ & A & EastAfricans & WestAfricans & $-3.59 \mathrm{E}-04$ & $2.59 \mathrm{E}-04$ & 0.165122 \\
\hline
\end{tabular}




\begin{tabular}{|c|c|c|c|c|c|c|c|c|}
\hline$B N C 2$ & rs 12350739 & G & A & EastAfricans & WestAfricans & $1.55 \mathrm{E}-04$ & 4.99E-04 & 0.756223 \\
\hline$D D B 1$ & rs11230664 & $\mathrm{C}$ & $\mathrm{T}$ & EastAfricans & WestAfricans & $-5.95 \mathrm{E}-04$ & $2.06 \mathrm{E}-04$ & 0.003833 \\
\hline$D D B 1$ & rs7120594 & $\mathrm{T}$ & $\mathrm{C}$ & EastAfricans & WestAfricans & $-3.15 \mathrm{E}-04$ & $1.83 \mathrm{E}-04$ & 0.084296 \\
\hline$D D B 1$ & rs7948623 & A & $\mathrm{T}$ & EastAfricans & WestAfricans & $5.57 \mathrm{E}-04$ & $1.79 \mathrm{E}-04$ & 0.001852 \\
\hline$D D B 1$ & rs1377457 & $\mathrm{C}$ & A & EastAfricans & WestAfricans & $-6.26 \mathrm{E}-04$ & $2.11 \mathrm{E}-04$ & 0.003034 \\
\hline TPCN2 & rs 35264875 & A & $\mathrm{T}$ & EastAfricans & WestAfricans & 0.001016 & $2.16 \mathrm{E}-04$ & $3.00 \mathrm{E}-06$ \\
\hline TPCN2 & rs3829241 & $\mathrm{G}$ & A & EastAfricans & WestAfricans & $-6.90 \mathrm{E}-05$ & 2.63E-04 & 0.792385 \\
\hline$T Y R$ & rs1042602 & $\mathrm{C}$ & A & EastAfricans & WestAfricans & $5.30 \mathrm{E}-05$ & 4.89E-04 & 0.914067 \\
\hline$T Y R$ & rs1393350 & $\mathrm{G}$ & A & EastAfricans & WestAfricans & $6.43 \mathrm{E}-04$ & $6.29 \mathrm{E}-04$ & 0.306763 \\
\hline$T Y R$ & rs1126809 & $\mathrm{G}$ & A & EastAfricans & WestAfricans & $5.30 \mathrm{E}-05$ & 4.89E-04 & 0.914067 \\
\hline KITLG & rs642742 & A & $\mathrm{G}$ & EastAfricans & WestAfricans & $1.53 \mathrm{E}-04$ & $1.92 \mathrm{E}-04$ & 0.423979 \\
\hline KITLG & rs 12821256 & $\mathrm{~T}$ & $\mathrm{C}$ & EastAfricans & WestAfricans & 0.001505 & 4.73E-04 & 0.001479 \\
\hline$D C T$ & rs1407995 & $\mathrm{T}$ & $\mathrm{C}$ & EastAfricans & WestAfricans & $9.90 \mathrm{E}-05$ & $1.85 \mathrm{E}-04$ & 0.594727 \\
\hline$D C T$ & rs2031526 & G & A & EastAfricans & WestAfricans & $-8.20 \mathrm{E}-05$ & $2.21 \mathrm{E}-04$ & 0.712095 \\
\hline SLC24A4 & rs12896399 & G & $\mathrm{T}$ & EastAfricans & WestAfricans & $9.73 \mathrm{E}-04$ & $2.81 \mathrm{E}-04$ & $5.26 \mathrm{E}-04$ \\
\hline SLC24A4 & rs 2402130 & G & A & EastAfricans & WestAfricans & $1.30 \mathrm{E}-04$ & $1.78 \mathrm{E}-04$ & 0.464636 \\
\hline OCA2 & rs2311843 & $\mathrm{C}$ & $\mathrm{T}$ & EastAfricans & WestAfricans & $-2.14 \mathrm{E}-04$ & $3.06 \mathrm{E}-04$ & 0.483851 \\
\hline$O C A 2$ & rs1800414 & A & $\mathrm{G}$ & EastAfricans & WestAfricans & $6.43 \mathrm{E}-04$ & $6.29 \mathrm{E}-04$ & 0.306763 \\
\hline$O C A 2$ & rs1800404 & $\mathrm{C}$ & $\mathrm{T}$ & EastAfricans & WestAfricans & $-3.51 \mathrm{E}-04$ & 2.24E-04 & 0.11748 \\
\hline$O C A 2$ & rs1800401 & $\mathrm{C}$ & $\mathrm{T}$ & EastAfricans & WestAfricans & $-4.59 \mathrm{E}-04$ & $2.24 \mathrm{E}-04$ & 0.040104 \\
\hline HERC2 & rs1129038 & G & A & EastAfricans & WestAfricans & $-5.60 \mathrm{E}-05$ & 4.81E-04 & 0.90728 \\
\hline HERC2 & rs12913832 & A & $\mathrm{G}$ & EastAfricans & WestAfricans & $-5.60 \mathrm{E}-05$ & 4.81E-04 & 0.90728 \\
\hline HERC2 & rs916977 & $\mathrm{A}$ & $\mathrm{G}$ & EastAfricans & WestAfricans & $-4.02 \mathrm{E}-04$ & $2.59 \mathrm{E}-04$ & 0.120361 \\
\hline HERC2 & rs1667394 & G & A & EastAfricans & WestAfricans & $-3.59 \mathrm{E}-04$ & $2.59 \mathrm{E}-04$ & 0.165122 \\
\hline$S L C 24 A 5$ & rs1426654 & $\mathrm{G}$ & A & EastAfricans & WestAfricans & $-1.57 \mathrm{E}-04$ & 2.39E-04 & 0.509837 \\
\hline MYO5A & rs4776053 & $\mathrm{C}$ & $\mathrm{T}$ & EastAfricans & WestAfricans & $-8.90 \mathrm{E}-05$ & $2.08 \mathrm{E}-04$ & 0.66729 \\
\hline
\end{tabular}




\begin{tabular}{|c|c|c|c|c|c|c|c|c|}
\hline$M C 1 R$ & rs2228479 & $\mathrm{G}$ & A & EastAfricans & WestAfricans & $6.43 \mathrm{E}-04$ & $6.29 \mathrm{E}-04$ & 0.306763 \\
\hline$M C 1 R$ & rs885479 & G & A & EastAfricans & WestAfricans & $6.43 \mathrm{E}-04$ & $6.29 \mathrm{E}-04$ & 0.306763 \\
\hline MFSD12 & rs56203814 & $\mathrm{C}$ & $\mathrm{T}$ & EastAfricans & WestAfricans & $-1.27 \mathrm{E}-04$ & $1.86 \mathrm{E}-04$ & 0.494038 \\
\hline MFSD12 & rs 10424065 & $\mathrm{C}$ & $\mathrm{T}$ & EastAfricans & WestAfricans & $3.51 \mathrm{E}-04$ & $1.78 \mathrm{E}-04$ & 0.048901 \\
\hline MFSD12 & rs6510760 & G & A & EastAfricans & WestAfricans & $3.81 \mathrm{E}-04$ & 2.24E-04 & 0.089162 \\
\hline MFSD12 & rs112332856 & $\mathrm{T}$ & $\mathrm{C}$ & EastAfricans & WestAfricans & 5.39E-04 & 2.23E-04 & 0.015703 \\
\hline$A S I P$ & rs6119471 & G & $\mathrm{C}$ & EastAfricans & WestAfricans & $5.78 \mathrm{E}-04$ & $1.79 \mathrm{E}-04$ & 0.001269 \\
\hline$A S I P$ & rs6058017 & G & A & EastAfricans & WestAfricans & $1.35 \mathrm{E}-04$ & $1.82 \mathrm{E}-04$ & 0.458646 \\
\hline$P I G U$ & rs2378249 & A & G & EastAfricans & WestAfricans & $-3.31 \mathrm{E}-04$ & $2.07 \mathrm{E}-04$ & 0.109172 \\
\hline
\end{tabular}

699 
In this section, we examined how the estimated selection difference $\hat{d}_{i j}=\left(\ln \frac{\hat{p}_{i}}{\hat{q}_{i}}-\ln \frac{\hat{p}_{j}}{\hat{q}_{j}}\right) / t$ that will be used later.

Inequality 1: If $a>b>0, c>d>0$, then $a c>b d$ and $\frac{a+d}{b+c}<\frac{a}{b}$.

Proof: $a>b>0, c>d>0$, then $a c>b c, b c>b d$. Therefore, $a c>b d$. Furthermore, $a c+a b>b d+a b$, which is the same as $a(b+c)>b(a+d)$. Therefore, $\frac{a+d}{b+c}<\frac{a}{b}$.

Inequality 2: If $a_{1}>0, a_{2}>0, \mathrm{~L}, a_{n}>0, \bar{a}=\sum_{i=1}^{n} a_{i} / n$, then $\max \left\{a_{1}, a_{2}, \mathrm{~L}, a_{n}\right\} \geq \bar{a}$, $\min \left\{a_{1}, a_{2}, \mathrm{~L}, a_{n}\right\} \leq \bar{a}$.

Proof: Let $a_{\max }=\max \left\{a_{1}, a_{2}, \mathrm{~L}, a_{n}\right\}$, then

$$
\begin{aligned}
a_{\max }-\bar{a} & =\left(\sum_{i=1}^{n} a_{\max }-\sum_{i=1}^{n} a_{i}\right) / n \\
& =\sum_{i=1}^{n}\left(a_{\max }-a_{i}\right) / n \geq 0
\end{aligned},
$$

because $a_{\max } \geq a_{i}$.

Let $a_{\min }=\min \left\{a_{1}, a_{2}, \mathrm{~L}, a_{n}\right\}$, then

$$
\begin{aligned}
\bar{a}-a_{\min } & =\left(\sum_{i=1}^{n} a_{i}-\sum_{i=1}^{n} a_{\min }\right) / n, \\
& =\sum_{i=1}^{n}\left(a_{i}-a_{\min }\right) / n \leq 0
\end{aligned}
$$


Further, we have

$$
\begin{aligned}
\hat{p}_{i} \hat{q}_{j}-\hat{q}_{i} \hat{p}_{j} & =(1-\alpha)(1-\beta)\left(p_{i} q_{j}-q_{i} p_{j}\right)+\alpha \beta\left(q_{i} p_{j}-p_{i} q_{j}\right) \\
& =[(1-\alpha)(1-\beta)-\alpha \beta]\left(p_{i} q_{j}-q_{i} p_{j}\right) \\
& =(1-\alpha-\beta)\left(p_{i} q_{j}-q_{i} p_{j}\right)
\end{aligned}
$$

734

because $a_{\min } \leq a_{i}$.

For the proofs in below, we assume $\hat{d}_{i j}>0$ without loss of generality. If $\hat{d}_{i j}<0$, then we can exchange $i$ and $j$, and still obtain $\hat{d}_{j i}>0$.

\section{The effect of migration}

Suppose there is $\alpha$ proportion of individuals in the population $i$, which actually come from the population $j$; also, there is $\beta$ proportion of individuals in the population $j$, which actually come from the population $i$. Here, $\alpha, \beta \in\left[0, \frac{1}{2}\right)$, because we assume migrants should not become the majority of another population. Then we have

$$
\begin{aligned}
& \hat{p}_{i}=(1-\alpha) p_{i}+\alpha p_{j} \\
& \hat{q}_{i}=(1-\alpha) q_{i}+\alpha q_{j} \\
& \hat{p}_{j}=(1-\beta) p_{j}+\beta p_{i} \\
& \hat{q}_{j}=(1-\beta) q_{j}+\beta q_{i}
\end{aligned}
$$

Here, $p_{i}$ and $q_{i}$ are the true derived and ancestral allele frequencies in the population $i$,

respectively; $p_{j}$ and $q_{j}$ are the true derived and ancestral allele frequencies in the

population $j$, respectively. Therefore,

$$
\begin{aligned}
\hat{p}_{i} \hat{q}_{j} & =\left[(1-\alpha) p_{i}+\alpha p_{j}\right]\left[(1-\beta) q_{j}+\beta q_{i}\right] \\
& =(1-\alpha)(1-\beta) p_{i} q_{j}+\alpha(1-\beta) p_{j} q_{j}+\beta(1-\alpha) p_{i} q_{i}+\alpha \beta q_{i} p_{j} \\
\hat{q}_{i} \hat{p}_{j} & =\left[(1-\alpha) q_{i}+\alpha q_{j}\right]\left[(1-\beta) p_{j}+\beta p_{i}\right] \\
& =(1-\alpha)(1-\beta) q_{i} p_{j}+\alpha(1-\beta) p_{j} q_{j}+\beta(1-\alpha) p_{i} q_{i}+\alpha \beta p_{i} q_{j}
\end{aligned} .
$$

Because $\alpha, \beta \in\left[0, \frac{1}{2}\right)$, then $1-\alpha-\beta>0$; and $\hat{p}_{i} \hat{q}_{j}>\hat{q}_{i} \hat{p}_{j}$, therefore, $p_{i} q_{j}-q_{i} p_{j}>0$.

We also have $\frac{\hat{p}_{i}}{\hat{q}_{i}}=\frac{(1-\alpha) p_{i}+\alpha p_{j}}{(1-\alpha) q_{i}+\alpha q_{j}}=\frac{p_{i}+\frac{\alpha}{1-\alpha} p_{j}}{q_{i}+\frac{\alpha}{1-\alpha} q_{j}}$. Because $p_{i} q_{j}-q_{i} p_{j}>0$, we have 
$737 \frac{\hat{q}_{j}}{\hat{p}_{j}}=\frac{q_{j}+\frac{\beta}{1-\beta} q_{i}}{p_{j}+\frac{\beta}{1-\beta} p_{i}}<\frac{q_{j}}{p_{j}}$, therefore, $\frac{\hat{p}_{i} \hat{q}_{j}}{\hat{q}_{i} \hat{p}_{j}}<\frac{p_{i} q_{j}}{q_{i} p_{j}}$. According to the monotony of the

logarithmic function, we have $0<\ln \frac{\hat{p}_{i} \hat{q}_{j}}{\hat{q}_{i} \hat{p}_{j}}<\ln \frac{p_{i} q_{j}}{q_{i} p_{j}}$; thus, $0<\hat{d}_{i j}<d_{i j}$. In other words, if the true value.

\section{The effect of substructure}

Scenario 1: The population $j$ has $k$ subpopulations.

743 If the population $j$ has $k$ subpopulations, then $\hat{p}_{j}=\frac{\sum_{k} N_{j k} p_{j k}}{N_{j}}$. Here, $p_{j k}$ is the derived

744 allele frequency in the subpopulation $k$ of the population $j$. And $N_{j}$ is the population size of

745 the population $j, \quad N_{j}=\sum_{k} N_{j k}$. We denote the minimum of $p_{j k}$ as $\min \left(p_{j k}\right)$. Because $q_{j k}=1-p_{j k}$, then $\max \left(q_{j k}\right)=1-\min \left(p_{j k}\right)$. Based on Inequality $2, \hat{p}_{j}>\min \left(p_{j k}\right)$, $\hat{q}_{j}<\max \left(q_{j k}\right)$. Therefore, $\ln \frac{\hat{p}_{j}}{\hat{q}_{j}}>\ln \frac{\min \left(p_{j k}\right)}{\max \left(q_{j k}\right)}$. We have $\ln \frac{\hat{p}_{i}}{\hat{q}_{i}}-\ln \frac{\min \left(p_{j k}\right)}{\max \left(q_{j k}\right)}>\ln \frac{\hat{p}_{i}}{\hat{q}_{i}}-\ln \frac{\hat{p}_{j}}{\hat{q}_{j}}>0$.

Scenario 2: The population $i$ has $l$ subpopulations.

750 If the population $i$ has $l$ subpopulations, then $\hat{p}_{i}=\frac{\sum_{l} N_{i l} p_{i l}}{N_{i}}$. We denote the maximum of

$751 p_{i l}$ as $\max \left(p_{i l}\right)$. Then $\hat{p}_{i}<\max \left(p_{i l}\right), \hat{q}_{i}>\min \left(q_{i l}\right)$. Therefore, $\ln \frac{\max \left(p_{i l}\right)}{\min \left(q_{i l}\right)}>\ln \frac{\hat{p}_{i}}{\hat{q}_{i}}$, and 752 we have $\ln \frac{\max \left(p_{i l}\right)}{\min \left(q_{i l}\right)}-\ln \frac{\hat{p}_{j}}{\hat{q}_{j}}>\ln \frac{\hat{p}_{i}}{\hat{q}_{i}}-\ln \frac{\hat{p}_{j}}{\hat{q}_{j}}>0$.

$753 \quad$ Scenario 3: The population $i$ has $l$ subpopulations, and the population $j$ has $k$ subpopulations. 
754 Based on Scenario 1 and 2, we have $\ln \frac{\max \left(p_{i l}\right)}{\min \left(q_{i l}\right)}-\ln \frac{\min \left(p_{j k}\right)}{\max \left(q_{j k}\right)}>\ln \frac{\hat{p}_{i}}{\hat{q}_{i}}-\ln \frac{\hat{p}_{j}}{\hat{q}_{j}}>0$.

755 In summary, if populations $i$ and $j$ have subpopulations, and their estimated selection

756 difference is larger than zero, then at least one pair of their subpopulations has selection

757 difference larger than zero. Moreover, the estimated difference is smaller than the largest

758 difference between subpopulations.

759 


\section{Text S2. A sample script for simulation with SLiM 2.}

initialize() \{

initializeMutationRate(1e-8);

initializeMutationType("m1", 0.5, "f", 0.0);

initializeMutationType("m2", 0.5, "f", 0.0);

$\mathrm{m} 1$.mutationStackPolicy = "f";

m2.mutationStackPolicy = "f";

initializeGenomicElementType("g1", m1, 1.0);

initializeGenomicElement(g1, 0, 999999);

initializeRecombinationRate(1e-8); \}

1 \{ sim.addSubpop("p1", 12000); \}

1 late() \{

// Set the initial frequency of the beneficial allele to 0.001

targets $=$ sample $(p 1$. genomes, 24$)$;

targets.addNewDrawnMutation(m2, 499999); \}

300\{

\section{// Add West Africans}

sim.addSubpopSplit("p2", 12000, p1); \}

1000\{

\section{// Add East Africans}

sim.addSubpopSplit("p3", 12000, p1);

p1.setSubpopulationSize(5000); \}

1600\{

// Add Oceanians

sim.addSubpopSplit("p6", 5000, p1); \}

2000\{

// Add Europeans

sim.addSubpopSplit("p4", 5000, p1); \}

2300\{

// Add North Asians and p1 becomes East Asians

sim.addSubpopSplit("p5", 5000, p1); \}

3300:3600 \{

$\mathrm{t}=$ sim.generation -3300 ;

// Expansion in Europeans and North Asians

// Final effective population size becomes $\sim 10,000$

p4_size $=\operatorname{round}(5000 * \exp (0.0023 * \mathrm{t}))$;

// Expansion in Asians

// Final effective population size becomes $\sim 20,000$

$\mathrm{p} 1 \_$size $=\operatorname{round}(5000 * \exp (0.0046 * \mathrm{t}))$;

p4.setSubpopulationSize(asInteger(p4_size));

p5.setSubpopulationSize(asInteger(p4_size));

p1.setSubpopulationSize(asInteger(p1_size)); \}

$/ / \mathrm{s} 1=-0.0188 / 31 * 2=-0.001213$ 
804

805

806

807

808

809

810

811

812

813

814

815

816

817

818

819

820

821

822

823

824

825

826

827

828

829

830

831

832

833

834
301:3600 fitness(m2, p2) \{ return 0.998787; \}

$/ / \mathrm{s} 10=0.00398 / 31 * 2=0.0002568$

301:1000 fitness(m2, p1) \{return 1.000257; \}

$/ / \mathrm{s} 2=-0.0204 / 31 * 2=-0.001316$

1001:3600 fitness $(\mathrm{m} 2, \mathrm{p} 3)$ \{ return 0.998684; \}

$/ / \mathrm{s} 9=0.00813 / 31 * 2=0.0005245$

1001:1600 fitness(m2, p1) \{ return 1.000525; \}

$/ / \mathrm{s} 3=-0.00614 / 31 * 2=-0.0003961$

1601:3600 fitness(m2, p6) \{ return 0.999603; \}

$/ / \mathrm{s} 8=0.00665 / 31 * 2=0.0004290$

1601:2100 fitness(m2, p1) \{ return 1.000429; \}

$/ / \mathrm{s} 4=0.0249 / 31 * 2=0.001606$

2001:3600 fitness(m2, p4) \{ return 1.001613; \}

$/ / \mathrm{s} 7=0.000218 / 31 * 2=0.0000141$

2001:2300 fitness(m2,p1) \{ return 1.000014; \}

$/ / \mathrm{s} 5=0.00622 / 31 * 2=0.0004013$

2301:3600 fitness(m2, p5) \{ return 1.000401; \}

$/ / \mathrm{s} 6=-0.00480 / 31 * 2=-0.0003097$

2301:3600 fitness(m2, p1) \{ return 0.999690; \}

3600 late() \{

mut 1 = sim.mutationsOfType $(\mathrm{m} 2)$;

cat("Count:"

+ "lt" + "WAFlt" + sim.mutationCounts(p2, mut1) + "|t"

+ "\t" + "EAFlt" + sim.mutationCounts(p3, mut1) + "lt"

+ "lt" + "OCN\t" + sim.mutationCounts(p6, mut1) + "\t"

+ "lt" + "EURlt" + sim.mutationCounts(p4, mut1) + "lt"

+ "lt" + "NAS $\mid \mathrm{t} "$ + sim.mutationCounts(p5, mut1) + "|t"

+ "lt" + "EAS $\mid \mathrm{t} "$ + sim.mutationCounts(p1, mut1)

+ "ln");

sim.simulationFinished(); \} 